\title{
The Benevolent Paternalism of Japanese Criminal Justice
}

\author{
Daniel H. Foote $\dagger$
}

Models for a criminal-justice system based on an ethos of rehabilitation and reintegration-such as Llewellyn's "parental" and Griffiths' "family" models-have been regarded as idealistic but unworkable in the real world, except perhaps in totalitarian or primitive societies. Professor Foote, however, has found in Japan just such a model, which he labels "benevolent paternalism." The Japanese criminal-justice system is benevolent in that its goal is to achieve reformation and reintegration into society through lenient sanctions tailored to the offender's particular circumstances. The system is paternalism in that it allows substantial discretion to the state in both gathering and using information about the offender and the offense. Drawing upon his extensive research in Japanese sources, from statutes to statistics, Professor Foote examines the successes and failures of benevolent paternalism. While recidivism rates indicate that many offenders are indeed reintegrated into society, the system has a dark side, permitting intrusions into the offenders' interests in autonomy and due process. Recognizing that benevolent paternalism comes at a price and can maintain order only under certain societal and cultural conditions, this Article suggests ways in which the Japanese criminal-justice system can adapt to change. It also reminds us that it is in reconciling the offender with the community that the law comes to work.

\section{INTRODUCTION}

Japan's criminal-justice system has been widely praised both within Japan and abroad as both highly efficient and generally lenient. ${ }^{1}$ There is

$\dagger$ Assistant Professor of Law, University of Washington School of Law; Visiting Professor 1991, Special Research Scholar 1983-85, University of Tokyo Faculty of Law. A.B. 1976, J.D. 1981, Harvard University.

I would like to express nyy gratitude to Professors Kōya Matsuo, Masahito Inouye, Kuniji Shibahara, Setsuo Miyazawa, Hiraku Tanaka, John Haley, Mark Ramseyer, Arthur Rosett, Frank Uphan, and Thonas Weigend, Judge Takeo Setoguchi, and Mr. Haruki Sugiyana of the Tokyo District Public Prosecutor's Office for their helpful advice, comments, and criticism. The nistakes that renain are my own.

I. See, e.g., Walter L. Ames, Police and Community in Japan (1981); David H. Bayley, Forces of Order: Policing Modern Japan (2d ed. 1991); John O. Haley, Authority Wrthout Power: LaW and the Japanese Paradox 121-38 (1991); EzRa F. VoGel, JAPAN as Number ONe 204-22 (1979); Kazuo Kawakami, Nihon no keiji shihō no tokushoku-kensatsu no tachiba kara [Characteristics of Japanese Criminal Justice-From the 
much truth to these characterizations. Japan's clearance rate-the percentage of reported crimes that are solved-is among the highest in the world, ${ }^{2}$ and its conviction rate stands at over $99.8 \% .^{3}$ Yet fewer than $5 \%$ of the adult suspects considered by police to have committed Penal Code offenses are sentenced to prison; ${ }^{4}$ those who are sentenced to prison serve a median sentence of under two years. ${ }^{5}$ In the United States, by contrast, over $30 \%$ of arrestees are sentenced to prison ${ }^{6}$ where they spend an average of nearly four and one-half years. ${ }^{7}$

Standpoint of the Prosecution], in 1 KeII TETSUzuki [Criminal Procedure] 11 (Makoto Mitsui et al. eds., 1988).

By international standards, moreover, Japan's crime rate remains low. See RESEARCH AND Training Inst., Ministry of Justice, Gov't of JAPAN, Summary of THE White PaPER ON CRIME 26-28 (1989) [hereinafter WHITE PAPER ON CRIME 1988] (focusing primarily on crime trends and activities related to the treatment of offenders in 1988 and comparing Japan's crime rate to that of other industrialized nations); see also Kawakami, supra, at 22-23.

2. See WhITE PAPER ON CRIME 1988, supra note 1, at 26-28 (comparing clearance rates); see also Kawakami, supra note 1, at 22; Setsuo Miyazawa, Keiji seido o süji de miru me [Looking at the Criminal System Through Numbers], 427 HōGAKU SEMINĀ 32, 37 (1990). Miyazawa argues that Japan's clearance rate may be significantly overstated, partly because police, in order to make themselves appear more efficient, tend not to list all crimes of which they learn. Id. Given the likely underreporting of crime in other nations, however, it seems safe to say that at least in relative terms Japan's clearance rate is high. Miyazawa also suggests that, given the greater number of Japanese police officers per reported crime and the broad range of available tools (especially those for questioning suspects), police performance is not necessarily so impressive even in comparative terms. Id. Although those factors might help to explain the police performance, they should not undercut police achievements.

3. See 1989 Hōmu sōgō KenKyũsho, Hōmushō, HANZal hakusho [RESEARCh AND Training Inst., Ministry of Justice, White Paper on Crime] 614-15 [hereinafter 1989 HANZAI HAXUSHo]; Miyazawa, supra note 2, at 47.

4. This figure for 1988 is arrived at by adding the number of persons sentenced to death or actual time in prison for Penal Code offenses by first instance courts, see 2 JiMosōKyoKu, SAIKō saibansho, Shihō tōkei nenpō, Keui hen [General Secretariat, Supreme Court, Annual Report of Judicial Statistics, Criminal Cases] 196-97 (tbl. 36-1), 210-11 (tbl. 36-3) (1988) [hereinafter 1988 REPORT OF JUDICIAL STATISTICs], the number of persons sentenced to actual time in prison for Penal Code offenses by Petty Courts, see id. at 229 (tbl. 36-6), and the number of persons newly sentenced to death or actual time in prison for Penal Code offenses by appeals courts at either the first or second appellate level, see id. at 314 (tbl. 54), 330 (tbl. 60), 344 (tbl. 66), 348 (tbl. 70), and dividing the total by the reported number of "offenders" cleared by the police for Penal Code offenses (excluding cases involving professional or gross negligence causing death or bodily injury by traffic aceident), see WHITE PAPER ON CRIME 1988, supra note 1, at 62 (tbl. I-1). As discussed infra notes 158-61 and aceompanying text, the clearance figures are not ealculated on the basis of arrests. Consequently, there has been no judicial or other third-party confirmation of the police determination of this number.

5. See White Paper on Crime 1988, supra note 1, at 120 (tbl. IV-5).

6. See Marc Mauer, The Sentencing Project, Americans Behind Bars: A COMPARISON OF INTERNATIONAL RATES OF INCARCERATION 8 (1991).

7. See Bureau of Justice Statistics, U.S. Dep'T of Justice, Historical Corrections IN THE UNITED STATES, 1850-1984, at 43 (tbl. 3-16) (determining that the median incarceration sentence for prisoners sent to state institutions in 1981 was 53 months); see also BUREAU OF JUSTICE Statistics, U.S. DEP'T of Justice, Bureau of Justice Statistics Bulletin, Felony SENTENCES IN STATE CourTS, 1986, at 1, 4 (1989) [hereinafter BuREAU of Justice Statistics BULLETIN] (calculating that the nationwide mean incarceration sentence in 1986 was 4 years and 10 
Some commentators, however, remain skeptical of Japanese criminal justice. Takeo Ishimatsu, a former High Court judge who handled criminal matters for most of his forty-year career, recently generated shock waves within Japan by flatly asserting that prosecutors and not the courts conducted the real trials of Japanese criminal defendants. ${ }^{8}$ A leading criminal-procedure scholar and former president of Tokyo University, Ryūichi Hirano, went so far as to label Japan's criminal-justice system "abnormal," "diseased," and even "hopeless."

It is not unusual to find widely diverging views about criminal justice. Herbert Packer's exposition of the clash $\mathrm{m}$ the United States between the so-called "due process" and "crime control" models provides a classic example of such a divergence. ${ }^{10}$ Professor Hirano has advocated greater due-process rights im Japan, ${ }^{11}$ and his critique of the Japanese criminal-justice systen in certain respects reseinbles Packer's due-process inodel. The system against which Hirano is inveighing, however, is far different fronı Packer's crime-control inodel. Rather, both the proponents and detractors of Japan's criminal-justice system are talking about a systein that might inore properly be thought of in terms of yet a third model.

That "family inodel"12 was introduced in perhaps its most detailed form in 1970 by John Griffiths. In brief, Griffiths' inodel posits a criminal-justice system based both on love (similar to a parent's love for a child) and inutual respect, in which the authorities consider the best interests of the suspect and focus their primary efforts on rehabilitation of offenders. Somewhat earlier, Karl Llewellyn liad described a similar model, which lie called the "parental system."13 More recently, John Braitliwaite has adopted sucl a model as part of his "remtegrative sliam-

months, the median 3 years, the state-prison mean sentence 6 years and 9 months, and the median 5 years).

8. Takeo Ishimatsu, Wagakuni no keiji hikokunin wa, saibankan ni yoru saiban o hontō ni ukete iru no ka [Are Criminal Defendants in Japan Truly Receiving Trials By Judges?], 423 HöGAKU SEMINĀ 62, 62 (1990), tronslated in 22 LAW IN JAPAN 143 (1989) (asserting that criminal trials are merely "formal ceremony"). The article is based on a talk Judge Ishimatsu gave shortly before retiring from the Osaka High Court upon reaching the mandatory retirement age of 65 . His impending retirement presumably made him more willing to take such a stance publicly.

9. Ryüichi Hirano, Genkö keijisoshö no shindan [Diagnosis of Current Criminal Procedure], in 4 Dandõ Shigemitsu hakase koki shukuga ronbunshū [Collection of Works to Commemorate the Seventieth BirThday of DR. Shigemitsu Dandō] 407, 407 (Yasuhara Hiraba et al. eds., 1985), translated in 22 LAW IN JAPAN 129, 129 (1989).

10. Herbert L. Packer, The Limis of the Criminal Sanction 149-73 (1968) (eonceptualizing "two models of the criminal process").

11. See, e.g., RyŭIchl Hirano, Keiji soshōhö [The Law of Criminal Procedure] 106 (1958); see also infra note 334 and text accompanying note 338.

12. See John Griffiths, Ideology in Criminal Procedure or $A$ Third "Model" of the Criminal Process, 79 YALE L.J. 359, 371 (1970).

13. KARL N. LLEWELLYN, The Anthropology of Criminal Guilt, in JURISPRUDENCE: REALISM in Theory AND Practice 439, 447-50 (1962). 
ing" concept of crimmal justice. ${ }^{14}$ I had originally planned to borrow the term "family model," prefacing it with the adjective "inquisitive" to reflect an aspect of the model Griffiths did not address. In numerous discussions, however, I found the concept of "family" carries so many differing connotations - especially when used in a cross-cultural settingthat I have instead opted for a term that both reflects two contrasting aspects of the system and that I hope will be somewhat less value laden: the "benevolent-paternahism model."15

Griffiths' family model has continued to receive considerable attention. ${ }^{16}$ Despite its roots and parallels in the writings of Llewellyn, ${ }^{17}$ Roscoe Pound, ${ }^{18}$ and even Emile Durkheim, ${ }^{19}$ the model has generally been treated as unrealistic and infeasible, except perhaps in a totalitarian state or under certain very limited circumstances. ${ }^{20}$ However, the Japa-

14. John Braithwatte, Crime, Shame and Reintegration $56-57$ (1989). Braithwaite, an Australian criminologist, described the family model as a close relative of the "reintegrative shaming" model he proposed-and of which he suggested Japan might be one example. Id. at 61-65. I learned of Braithwaite's work only while writing this Article and was interested to find that we had independently been thinking of Japan in family-model terms. As will become apparent, I agree with much of Braithwaite's discussion of the strengths of Japan's criminal-justice system, but feel that he has paid insufficient attention to the tradeoffs and drawbacks inherent in that system.

15. When referring specifically to Griffiths' model, I will continue to use the term "family model."

16. See, e.g., William J. Genego, The New Adversary, 54 BrooK. L. REv. 781,845 n.236 (1988) (discussing Griffiths' challenge to Packer's models).

17. See LlEwellyN, supra note 13, at 447-50 (advocating an amalgam of our "arm's-length" system and the "parental" system of "primitive" cultures).

18. See Roscoe Pound, Criminal Justice in the American City, in CRIminal Justice IN Cleveland: Reports of the Cleveland Foundation SURVey of the Administration of Criminal Justice iN Cleveland, Ohio 559 (Roscoe Pound \& Felix Frankfurter eds., 1922), discussed in Griffiths, supra note 12, at 391-95.

19. See EMILe DURKheIm, From Repressive to Restitutory Law, in DURKheim AND the LAW 39 (Steven Lukes \& Andrew Scull eds., 1983). Durkheim referred to a similar model, with a focus upon mimimizing disruption and seeking to restore relations, as the "restitutive" model, which he contrasted to the so-called "repressive" model. Id. at 47-53.

20. See, e.g., Thomas A. Cowan, Law Without Force, 59 CAL1p. L. Rev. 683, 693 n.14 (1971) (welcoming alternatives to the battle model but dismissing the metaphor of family as inappropriate for a model of criminal sanction); Mirjan Damaška Structures of Authority and Comparative Criminal Procedure, 84 Y ALE L.J. 480, 530-31 (1975) [hereinafter Damaska, Structuresl (noting that parental ideology fits the system of criminal procedure "in tribal cultures or in those moderm societies that attempt to restrain antisocial conduct independently of state authority"); Phyllis Goldfarb, When Judges Abandon Analogy: The Problem of Delay in Commencing Criminal Prosecutions, 31 WM. \& MARY L. REv. 607, 671 n.310 (1990) (noting Griffiths' "astute critique" of Packer's work but rejecting the family model as an unrealistic option given existing ideology in the United States); cf. Kent S. Bernard, Structures of American Military Justice, 125 U. PA. L. REV. 307 (1976) (arguing that the U.S. military-justice system can be seen as a hybrid of family and adversary models); Mirjan Damaška, Evidentiary Barriers to Conviction and Two Models of Criminal Procedure: A Comparative Study, 121 U. PA. L. REv. 506, $571-73$ (1973) [hereinafter Damaška, Evidentiary Barriersl (noting parallels between "parental" or "family" models and socialist criminal procedure). But see Joachim Herrmann, Various Models of Criminal Proceedings, 2 S. AFr. J. CRIM. L. \& CRIMINologY 3, 16 (1978) (characterizing the current Swedish criminal-justice system as an example of a "parental model"). 
nese experience provides a strong indication that the model is neither "absurd" nor "utopian," as Griffiths correctly predicted some would consider it, ${ }^{21}$ nor limited to either primitive or stateless societies. ${ }^{22}$

I hesitate to use notions of love or even mutual respect, which were central to Griffiths' exposition of the family model, ${ }^{23}$ to characterize the attitudes of Japanese criminal-justice authorities toward crime suspects. Nor would I suggest that the best interests of the suspect are the authorities' primary objective. Rather, the objective of criminal justice in Japan, as in virtually every other nation, is maintaining order. Yet in the Japanese setting, maintenance of order is achieved in considerable measure through "specific prevention." This term, which has its roots in Continental criminal-justice systeins, should be distinguished from "specific deterrence." Whereas the concept of specific deterrence refers primarily to crime control achieved through intimidation, "specific prevention" is a broader concept that also embraces the prevention of recidivism through the reformation and rehabilitation of the offender. ${ }^{24}$ The distimction is of vital miportance in Japan, for Japan's criminal-justice system places great emphasis on the reintegration and rehabilitation of suspects in accordance with their individualized circumstances. As a consequence, although the theoretical concepts of love, respect, and concern are not the primary motivations for the actions of Japanese criminal-justice authorities, im practice the system closely parallels the family inodel.

The Japanese experience, however, also reveals other, less attractive features of a system based upon the family. In contrast to Griffiths' ideahzed family, which pays great regard to the personal autonomy of its members, the Japanese criminal justice system more closely resembles an "inquisitive" family that insists on keeping tabs on its members and learning everything it can about them if they come under suspicion. The Japanese experience forces us to confront whether a family-type model can be implemented without a considerable degree of such intrusiveness.

The Japanese criminal-justice systein is also characterized by the great trust placed in and the broad grants of discretion made to authorities that Griffiths and others have regarded as essential attributes of a family-type model. This is the "paternalistic" side of the model. ${ }^{25}$ As several recent cases have shown, however, when that trust proves unwarranted-when the relevant authorities make mistakes or when bias, deliberate or unintentional, infects the system-effective checks are for

21. Griffiths, supra note 12 , at 371.

22. Damaška, Structures, supra note 20, at 531.

23. Griffiths, supra note 12, at 371-72.

24. See Shigemitsu Dando, System of Discretionary Prosecution in Japan, 18 AM. J. CoMP. L. 518,518 n.1 (1970).

25. See Llewelly, supra note 13 , at 448 ; Griffiths, supra note 12 , at $380-83$. 
the most part lacking. ${ }^{26}$ Again we are forced to confront fundamental questions: Are there remedies Japan can administer that would not undermine the benefits of its system? And is the potential for unchecked mistake and bias an inevitable aspect of any benevolent-paternalism model? At first blush, the establishment of a more effective set of checks on prosecutorial activities would seem to offer soine promise in redressing these systemic problems. Reform could be achieved either through expanded in camera review of prosecutorial activities or through an invigorated adversary system. In the Japanese setting, however, such proposals face strong opposition: the former largely for historical reasons, the latter im part out of a fear that creating a "hired gun" mentality ultimately could undermine the system. ${ }^{27}$ Thus, the Japanese authorities seem to have responded to fears of mistakes by pushing for even more careful scrutiny of individual cases, including heightened investigations and inore intensive questioning by pohice and prosecutors, all to be conducted within the existing paternahstic framework.

Notwithstanding its troubling elements, the benevolent-paternalism model appears to function quite effectively in Japan. Nunnerous facets of Japanese society help to explain this evident success. Yet society and the criminal-justice systein currently face a wide range of pressures, soine of which pose novel cliallenges to orthodox thinking. Will Japan's existing approach to criminal justice remain viable in the future, or is it in danger of cruinbling under these new stresses? Although any long-term prognostication is risky, I will, in the final section of this Article, hazard a few guesses.

\section{I \\ Models of Criminal Justice}

\section{A. The Crime-Control Model and the Due-Process Model}

Commentators have long recognized two recurrent themes in American debate over the criminal-justice system: an emphasis on repression of criminal conduct, on the one hand, and a "solicitude"28 for the rights of the individual, on the other. Herbert Packer neatly synthesized these themes and labelled thein the "crime control" and "due process" inodels, respectively. ${ }^{29}$

The crime-control model, as Packer described it, "is based on the proposition that the repression of crininal conduct is by far the inost important function to be performed by the criminal process." ${ }^{30}$ The key

26. See infra notes 297-331 and accompanying text.

27. See infra notes 354-63 and accompanying text.

28. Pound, supra note 18 , at 577.

29. PACKER, supra note 10 , at 149-73.

30. Id. at 158 . 
to achieving that end, he concluded, is "the efficiency with which the criminal process operates to screen suspects, determine guilt, and secure appropriate dispositions of persons convicted of crime."31 Applying that inodel to the United States-where, as he noted, a wide range of behavior is treated as criminal, the amount of crime is very high, and increases in the quantity and quality of resources devoted to crime suppression are unlikely-Packer described several additional attributes of the inodel necessary for it to operate successfully. The model, according to Packer, "nuust produce a high rate of apprehension and conviction."32 The combination of high crime and limited resources requires an einphasis on "speed and finality."33 In turn, the desire for speed leads to an emphasis on both informality and uniforumity: by preferring such informal processes as interrogation at a police station to formal examination in open court, the "facts" can be established more quickly; and by treating cases in a uniform, basically administrative manner pursuant to "[r]outine, stereotyped procedures," the process can move to a prompt, "successful" conclusion. ${ }^{34}$

In the crime-control model, a successful conclusion is "[o]ne that throws off at an early stage those cases in which it appears unlikely that the person apprehended is an offender and then secures, as expeditiously as possible, the conviction of the rest, with a minimum of occasions for challenge, let alone post-audit." 35 The model is premised on "confidence in the rehability of informal administrative fact-finding activities ... in the early stages of the criminal process." 36 The only restrictions recognized on this preliminary administrative fact-finding should be those that "enhance reliability"; 37 the remainder of the process should be relatively perfunctory, based on the presuniption that the suspect is probably guilty. ${ }^{38}$ An additional characteristic of the model is its willingness to accept mistakes (includimg mistaken convictions) so long as the mistakes do not interfere with the efficiency deemed essential to repressing crime. ${ }^{39}$

Packer's due-process nodel, in contrast, "stresses the possibility of error"40 and places great weight on avoiding mistakes. In place of the crime-control nodel's confidence in administrative fact-finding, the dueprocess model "insist[s] on formal, adjudicative, adversary fact-finding

\footnotetext{
31. Id.

32. Id. at 159.

33. Id.

34. Id. at $159-60$.

35. Id. at 160 .

36. Id. at $160-61$.

37. Id. at 162.

38. Id. at $160-62$.

39. Id. at 164-65.

40. Id. at 163 .
} 
processes in which the factual case against the accused is publicly heard by an impartial tribunal." 41 In addition to this emphasis on reliability rather than efficiency, the due-process model is also premised on the complementary concepts of "the primacy of the individual and ... limitation on official power."42 Motivated by a concern over the potential for abuse of power, the due-process model estabhishes numerous restrictions on administrative fact-finding and vindicates those restrictions through the criminal process itself by excluding evidence and reversing convictions even im cases in which the evidence strongly points to guilt. ${ }^{43}$

Packer notes two additional forces behind the due-process model: a concern for equality of justice ${ }^{44}$ and a "skepticisin about the morality and utility of the criminal sanction" itself. ${ }^{45}$ The ideological underpinnings of the due-process model are thus broader than those of the crime-control model, and the confluence of these various themes results in a model that emphasizes formal processes, individualized consideration, and the opportumity for careful review.

\section{B. The Battle Model and the Family Model}

Packer claimed that his two models embraced the entire range of value choices underlying the criminal process. ${ }^{46}$ Griffiths took issue with that characterization, arguing that Packer's two models in fact represented only two aspects of a single model-what Griffiths labelled the "battle model" - and that one could imagine other possible models, most notably the family model. ${ }^{47}$ Griffiths noted that Packer assumed a fundamental irreconcilability between the interests of the state and the interests of the individual. The basic goal of the state, as Griffiths interpreted Packer, is "to put a suspected criminal in jail";";8 the goal of the individual is, presumably, to stay out of jail. Both the crime-control and dueprocess models, suggested Griffiths, share a common conception of

41. Id. at 163-64.

42. Id. at 165 .

43. Id. at $167-68$.

44. Id. at $168-70$.

45. Id. at 170 .

46. Id. at $152-53$ ("[W] need [a model] . . that permits us to recognize explicitly the value choices that underlie the details of the criminal process. ... It will take more than one model, but it will not take more than two.").

47. Griffiths, supra note 12, at 367-95. For other critiques of Packer, see Peter Arenella, Rethinking the Functions of Criminal Procedure: The Warren and Burger Courts' Competing Ideologies, 72 GEO. L.J. 185, $209-29$ (1983) (restructuring Packer's models to provide a framework for evaluating judicial trends in criminal procedure), Damaška, Evidentiary Barriers, supra note 20, at 574-77 (questioning the "confrontation" between the crime-control and due-process models), and Abraham S. Goldstein, Reflections on Two Models: Inquisitorial Themes in American Criminal Procedure, 26 STAN. L. REV. 1009, 1015-25 (1974) (suggesting additional accusatorial and inquisitorial models).

48. PACKER, supra note 10, at 151, quoted in Griffiths, supra note 12, at 367. 
implacable hostility between the individual and the state: the models differ only in where they place the balance in the battle between the adversaries. ${ }^{49}$ Thus, Griffiths concluded, "[w] hat [Packer] gives us is a simgle Battle Model with two possibilities of bias." 50

Griffiths suggested that one can imagine an alternative criminal-justice system premised not on "disharmony, fundamentally irreconcilable interests, a state of war," but rather on "reconcilable-even inutually supportive-interests, a state of love." 51 Taking as his template the institution of the family, Griffiths offered a number of attributes for this family inodel. First and foremost, the systein would be based not on pumishment as such, but on seeking to reform the offending member, keeping that individual's best imterests at heart:

Reconciliation takes place ... particularly in the energetic pursuit by society of the convict's interest in every way consistent with the social need that he be punished. His sacrifice for the general good is kept to a minimuin. The experience is made as painless and as beneficial for hin as possible. In concrete ways we can make plain that while le has transgressed, we do not therefore cut him off from us; our concern and dedication to his well-being continue. We have punished hin and drawn him back in among us; we have not cast him out to fend for himself against our systenratic enmity. ${ }^{52}$

In Griffiths' formulation, this approach in turn would have a wide variety of implications for the criminal process. Among the inost notable of these would be a "basic faith in public officials," family inodel "could not exist": 54 " $[\mathrm{E}]$ veryone would assurne . . . that if a public official has a particular role or duty, he can be expected to carry it out in good faith and using his best judginent."5s

One might ask whether Griffiths was simply talking about a different phase of the criminal process than was Packer. As Griffiths pointed out, law school education about (and, one might add, public discussion of) the criminal-justice system in the United States focuses almost exclusively on the process up through conviction and on postconviction challenges to the conviction. ${ }^{56}$ The postconviction corrections process is largely invisible. ${ }^{57}$ The dominant attitude in the United States remains, as Griffiths suggested twenty years ago, that conviction will be followed

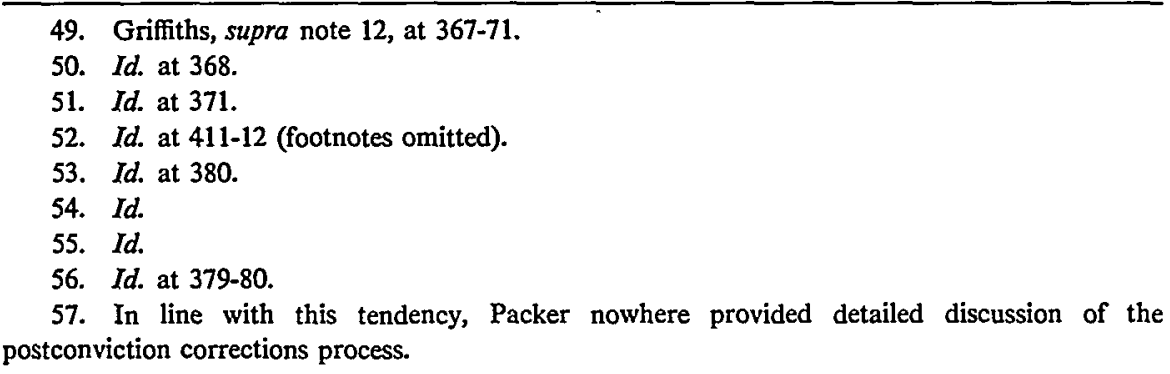


by "exile," and what happens there is of relatively little concern. ${ }^{58} \mathrm{~A}$ greater emphasis on postconviction treatment and rehabilitation does not, however, seem inconsistent with either branch of the battle model. Might Griffiths have been looking at simply one phase of the process, the postconviction phase, and suggesting that the existing "exile" ideology be replaced with one of rehabilitation?

The answer is no. Griffiths suggested precisely a process that does not treat corrections and rehabilitation as a mere final step, or an afterthought, but rather regards those objectives as integral elements of the process from the very start. It is not always obvious, however, what he envisioned for the earlier stages of the process. As inentioned above, Griffiths argued that the family model would require faith in public offcials and trust that they will not abuse their powers. ${ }^{59}$ But he did not seek to define what, if any, the himits on those powers should be. Griffiths seemed to envision a system that would entail very little intrusion on the personal autonomy of individuals. He stated that the family Inodel would "minimize[ ] social intervention by limiting such intervention to situations in which an individual has failed to exercise the required self-control." 60 In addition, he claimed that under the family model the "change in our attitude toward criminal defendants would bring with it a thoroughgoing respect for their rights and their dignity and their individuality, going far beyond the purely formal respect which now attaches to the defendant." 61 This thoroughgoing respect, he suggested, would carry with it a notion of protection for the integrity of the persons and homes of the guilty as well as of the innocent. ${ }^{62}$ Ultimately, Griffiths seeined to imagine a world in which criminal-justice authorities leave everyone alone unless someone commits a transgression necessitating intervention, at which point they respond with love and respect, maintaining the rehabilitation of the individual as their key goal.

Griffiths notably failed to explain how the investigative process might function in this ideal world. Nor did he consider how the officials responsible for running his system inight obtain the information they need to decide what treatment best met the needs of the accused. He clearly assumed that officials will in fact have all relevant informationnot just about the offense, but even more importantly about the personal circumstances of the suspect. He even suggested that defense counsel would have a duty to aid in assembling that information. ${ }^{63}$ But he seened to think that this information could be gathered without any sub-

\footnotetext{
58. PACKER, supra note 10, at 378-79.

59. See supra note 53 and accompanying text.

60. PACKER, supra note 10 , at 374 .

61. Id. at 384 .

62. Id. at $384-85$.

63. Id. at 383 .
} 
stantial intrusion on personal autonomy. In the absence of any principles that limit intrusions on personal autonomy, however, the familial caretaking in Griffiths' regime might come at a steep price.

\section{The Benevolent-Paternalism Model}

Griffiths expressly acknowledged that his family model was nowlere directly applicable; he was simply "set[ting his] mind[] free to wonder"64 about possible alternatives. One could just as easily miagine an alteruative, however, that would display concern for reliabilitation and reform of the offender but would lack the family model's respect for the personal autonomy of the individual. This alternative, which I refer to as the benevolent-paternalism model, would also be characterized by great faith in public officials. Yet this model would not ouly permit, indeed it would expect, public officials to maintain careful watch over the meinbers of society. At least in cases in which individuals are suspected of misbehavior, moreover, the benevolent-paternalism inodel would entrust public officials with the authority to intrude on the personal autonomy of suspects to the extent deemed appropriate both for clarifying the nature of the individual's conduct and for determining the most suitable means of achieving reforınation. The authorities would be given a relatively free hand to uncover whatever information they considered relevant, but after uncovering that information they would be expected to treat the suspect in the manner most suited to rehabilitation and reintegration into the community.

As thus defined, this benevolent-paternalisn resemblance to the "parental system" Karl Llewellyn observed in the criminal justice systems of the Cheyenne and the New Mexican Pueblos. ${ }^{65}$ In that model

[a] "trial" lies half in an inquiry by officials, an inquiry reaching "real evidence" (tracks, etc.), and all available testinony, including that of the suspect or accused; what he has to say in argument or extenuation is part of this phase. ... What is known as the "trial," the second half of the procedure, is formal on the point of fact, except in an exceptional case. Its purpose is instead to bring the erring brother, now known to be such, to repentance, to open confession, and to reintegration with the community of which he was and still is regarded as an integral part. ${ }^{66}$

Like Griffiths, Llewellyn did not describe the investigative process in this parental system in any detail. Yet Llewellyn's references to an inquiry into all the evidence, including the testimony of the suspect, and to a trial designed to induce "repentance ... [and] . . open confession," suggested

64. Id. at 417 .

65. LlewElLyN, supra note 13 , at $447-48$.

66. Id. at 448 . 
an emphasis quite different from Griffith's thoroughgoing respect for the mdividuality of suspects and defendants. The system Llewellyn depicted countenances, and even encourages, considerable intrusion on the personal mtegrity of the accused as an essential element of the rehabilitative process. Despite significant differences-especially in the division of functions between the investigative phase and the formal trialLlewellyn's parental system is strikingly similar to Japan's criminal-justice system, to which I now turn.

II

\section{JAPAN'S CRIMINAL-JUSTICE SYSTEM}

\section{A. Historical Overview}

Before turning to an examination of criminal justice in Japan today, a brief historical excursus may be useful. Durmg the Tokugawa era (1600-1868), members of the public bore a broad duty to assist investigative officials in reporting crimes. ${ }^{67} \mathrm{~A}$ further key source of information on crime was the so-called meakashi, private persons whom shogunate officials paid to uncover crime and arrest suspects. ${ }^{68}$ Apparently, however, offenders often paid meakashi not to reveal crimes. Given widespread reports of these and other abuses, the level of respect for meakashi probably was not high. ${ }^{69}$ The collection of evidence and close questioning of suspects by meakashi, however, along with intensive pretrial questioning by shogunate investigators, permitted shogunate officials to guard against the possibility of an acquittal at the ultimate trial stage. The occurrence of such an acquittal was regarded as a disgrace that might undermine respect in the shogunate officials themselves. ${ }^{70}$

Confessions played a central role in the Tokugawa criminal process, and torture was an accepted and carefully codified means of obtaining them. ${ }^{71}$ Confessions were regarded as the best evidence of truth and

67. See Yoshirō Hiramatsu, KINSEI KeIJisoshōhō NO KENKYū [A STUdy OF THE LAW OF, Criminal Procedure IN THE Recent ERA] 599-601 (1960), summarized and translated in $22^{\circ}$ LAW IN JAPAN 105, 106 (1989) (stating that in cases of major crime, there was a public duty to arrest the perpetrator and report the crime: failure to do so was subject to punishment while performance of the duty was to be rewarded).

68. HIRAMATSU, supra note 67, at 626-47, summarized and translated in 22 LAW IN JAPAN 105, 107-09 (1989).

69. See HiRAmatsu, supra note 67, at 626-47, summarized and translated in 22 LAW IN JAPAN 105, 107-09 (1989) (pointing out that some meakashi ran gambling and prostitution rings, extorted money from criminals and innocents, and falsified evidence).

70. HiRAmaTSU, supra note 67, at 694-97, summarized and translated in 22 LAW IN JAPAN 105, 111-12 (1989).

71. See Hiramatsu, supra note 67, at 774-827, summarized and translated in 22 LAW IN JAPAN 105, 118-21 (1989); Haruo Abe, Self-Incrimination-Japan and the United States, 46 J. Crim. L. Criminology \& Police ScI. 613, 613-15 (1956). For a discussion of the role of confessions in Japan historically and at present, see Daniel H. Foote, Confessions and the Right to Silence in Japan, 21 GA. J. INT'L \& COMP. L. 415 (1991). 
reportedly also played an important role in maintaining public trust in the shogunate crininal-justice process by ensuring that those accused of crime had subnitted to public authority. ${ }^{72}$ There is little to suggest, however, that confessions served a rehabilitative purpose, at least during the first half of the Tokugawa period. On the contrary, during that period the einphasis was squarely on general deterrence, achieved through the public imposition of harsh penalties, such as parading the heads of offenders. ${ }^{73}$ Even during the last half of the Tokugawa period, Japan's criminal-justice system continued to be characterized by stiff penalties. As late as 1873, five years after the Meiji Restoration, over 900 people were executed in a one-year period in Japan. ${ }^{74}$

Nonetheless, during the long era of peace and stability in Tokugawa Japan the criminal-justice system increasingly became characterized by elements of specific prevention. ${ }^{75}$ The authorities regularized the use of pardons with exphicit emphasis on rehabilitative goals ${ }^{76}$ and established a system for putting soine offenders to work at hard labor, again with expressly rehabilitative objectives. ${ }^{77}$ Spurred at least in part by Western influence, this trend accelerated in the Meiji era. By as early as 1885, Justice Minister Yamada was urging limiting the use of imprisonment for ininor crimes-in part to save noney, but in part to avoid recidivisin. ${ }^{78}$ And in 1914 Procurator General Hiranuina sharply rejected the notion that all offenders inust be punished, instead urging the widespread use of oral exhortations and adinonislıments in cases in which those steps would be sufficient to prevent future wrongdoing. ${ }^{79}$ This trend toward specific prevention also received strong theoretical support from

72. See HIRAMATSU, supra note 67 , at 831 , summarized and translated in 22 LAW IN JAPAN $105,121-22$ (1989) (suggesting that a conviction not accompanied by confession was suspect and often resulted in lesser punishment).

73. See Ryōsuke Ishi, Edo no keibatsu [Punishment IN THE Edo ERA] 11-12 (1964).

74. Miyazawa, supra note 2 , at 53. The Tokugawa criminal-justice system, with its eunphasis on confessions coupled with provisions for leniency for those who voluntarily turned themselves in and confessed, derived from and bears striking resemblance to traditional Chinese criminal justice. See W. Allyn Rickett, Voluntary Surrender and Confession in Chinese Law: The Problem of Continuity, $30 \mathrm{~J}$. AsIAN STUD. 797 (1971) (tracing role of confession in Chinese legal history). Similar attitudes characterize both Japanese and Chinese criminal justice today. For a discussion of the inportance of confession in the context of thought control in Japan and China, see RICHARD H. Mitchell, Thought Control in Prewar JAPAN $190-92$ (1976).

75. See IsHII, supra note 73 , at $12-17$.

76. Id. at $14-15$.

77. Id. at $15-16$.

78. See Terumasa Ide \& Yasuko Satō, Kiso yūyo shobun ni fusareta mono no nariyuki ni kansuru kenkyū [A Study on the Results of Suspension of Prosecution], in HōMU sōGō KENKYŪSHO, HōMUSHō, HōMU SōGō KeNKYūsho KENKYūBu KIYō, DAI-1 BUNSATSU [RESEARCH AND Training Institute, Ministry of Justice, Bulletin of the Criminological Research DepartMENT, PART 1] 1, 1-2 (1968).

79. See Noriharu Tashiro, Kiso yūyo seido no konnichiteki kadai [Current Issues Concerning the System of Suspension of Prosecution] (pt. 1), 711 KEISATSU KENKYū 20, 25-26 (1989). 
Japanese adherents of the so-called "new school" of criminal justice. Influenced by the thinking of European scholars, this school, which gained considerable strength in Japan early in this century, emphasized that criminal behavior was the result of identifiable causes ${ }^{80}$ and that the primary role of penalties therefore should be to eliminate these underlymg causes through education, rehabilitation, and specific deterrence. ${ }^{81}$

Western-influenced reforms of other aspects of criminal procedure following the Meiji Restoration included a prohibition of torture and elimination of the requireinent that convictions be based on confessions. ${ }^{82}$ As a practical matter, however, confessions remained the centerpiece of most proceedings. Investigators used a wide variety of tools, including intimidation and physical abuse, to procure confessions from unwilling suspects. ${ }^{83}$ Yet in keeping with the trend toward specific prevention described above, there are clear indications that sincere confessions came to be regarded as playing an important role in the rehabilitation of suspects and their reintegration into society. The most celebrated such example was the "conversion" (tenko) of thousands of leftists who repudiated their communist ideology and in turn received complete forgiveness from governmental authorities. ${ }^{84}$

During the period through the end of World War II investigators had broad authority to conduct searches and seizures. ${ }^{85}$ In keeping with the Contmental model on which the Japanese criminal-justice system was based, a "preliminary judge" conducted a second, preliminary investigation after police and prosecutors conipleted their initial investigation. ${ }^{86}$ The results of that judge's preliminary investigation, which included further questioning of the suspect, were set forth in a dossier that in principle contained all the files relating to the case. The trial consisted primarily of a confirnation of the findings of the preliminary investigation based on a review of the written record and questioning of the

80. See Ryūichi Hirano, 1 Keihösōron [CRIMinal LAw, Introduction] 3-16 (1972). Ironically the "old school" to which this "new school" responded was itself a direct import from Europe. To make matters even more confusing, both the "old school" and the "new school" entered Japan at virtually the same time. See id. at 5-8, 14 .

81. Id. at 3-16.

82. John Gadsby, Some Notes on the History of the Japanese Code of Criminal Procedure, 30 LAW Q. REV. 448, 452 (1914).

83. See Abe, supra note 71, at 618 .

84. See MrTCHELL, supra note 74 , at 109-47.

85. Warrant requirements existed, but there were broad exceptions for "urgent investigations." See Seitchirō ONo, Keiji soshōhō kōgi [Lectures on the Law of Criminal Procedure] 263-73 (1941); see also Toshitaka Ushiomi \& Yōzō Watanabe, Senzen ni okeru Nihon no keisatsu [Prewar Japanese Police], in Keisatsuxen [Police Power] 52, 84-90 (Michitaka Kainō ed., 1960) (describing search techniques).

86. See Atsushi Nagashima, The Accused and Society: The Administration of Criminal Justice in Japan, in LAw IN JAPAN: The Legal ORder IN A Changing Society 297, 312-13 (Arthur T. von Mehren ed., 1963). 


\section{defendant. $^{87}$}

Following World War II, the Allied Occupation sought to achieve "fundamental change of the criminological attitude" in Japan. ${ }^{88}$ This task deinanded basic changes in numerous aspects of Japan's criminaljustice system through the estabhishment of a broad set of constitutional protections as well as statutory revisions. ${ }^{89}$ The Occupation reforms included strengthening the warrant requirements for both arrests and searches, and estabhishing broad himits on searches and seizures. ${ }^{90}$ Particularly important was a set of interrelated constitutional and statutory provisions designed to restrict opportumities to obtain confessions and to limit prosecutorial reliance on confessions. The reforms erected a constitutional privilege against self-incrimination, ${ }^{91}$ a statutory right to refuse to answer questions (coupled with a duty of investigators to notify the suspect of that right), ${ }^{92}$ and both constitutional and statutory prohibitions against admission at trial of coerced confessions. ${ }^{93}$ The Occupation also sought to foster a vigorous adversary system and to ensure that the formal trial itself would be the key step in the criminal-justice process. To this end, the new procedure abolished the pretiminary judge's examination of suspects and established strict rules against the use of hearsay

87. Id. at 316-317.

88. 2 Government Section, Supreme Commander for the Allied Powers, Political Reorientation of Japan: September 1945 to September 1948, at 227 (1948) [hereinafter SCAP].

89. See id. at 227-31 (detailing revisions in Code of Criminal Procedure). See generally Richard B. Appleton, Reforms in Japanese Criminal Procedure under Allied Occupation, 24 WasH. L. REv. 401 (1949).

90. See Appleton, supra note 89, at 408-12 (explaining new warrant requirements).

91. See KENPō [CONSTrTution] art. 38, para. 1, translated in CONSTITUTrONS OF THE COUNTRIES OF THE WORLD: JAPAN 17 (Albert P. Blaustein \& Gisbert H. Flanz eds. \& T.S.Y. Lee \& Osamu Nishi trans., 1990) ("No person shall be compelled to testify against himself.").

92. KeII SoshōHō [KeIsohō] art. 198(1) (Code of Criminal Procedure, Law No. 131 of 1948), translated in 2 EIBUN-HoREI-SHA LAW BULLETIN SERIES RA-RB, at RA 42-RA 43 (1988) ("A public procurator, a secretary of the public procurator's office or a policeman may, when it is necessary for conducting an investigation of an offense, request the suspect to appear and examine him: Provided, that the suspect may, except in cases where under arrest or detention, refuse to appear, or leave at any time after appearance." (translation emended by the author)); KEIsOHō art. 198(2) (Code of Criminal Procedure, Law No. 131 of 1948), translated in 2 EibUN-HoreI-SHA LAW BULLETIN SERIES RA-RB, at RA 43 ("At the examination referred to in the preceding paragraph, the suspect shall be notified in advance that he need not make statements against his will." (translation emended by the author)).

93. KENPŌ [CONSTITUTION] art. 38, para. 2, translated in CONSTITUTIONS OF THE COUNTRIES OF THE WORLD: JAPAN 17-18 (Albert P. Blaustein \& Gisbert H. Flanz eds. \& T.S.Y. Lee \& Osamu Nishi trans., 1990) ("Confession made under compulsion, torture or threat, or after prolonged arrest or detention shall not be admitted in evidence."); KEISOHō art. 319(1) (Code of Criminal Procedure, Law No. 131 of 1948), translated in 2 EIBUN-HoREI-SHA LAW BULLETIN SERIES RA-RB, at RA 69 (1988) ("Confessions made under compulsion, torture or threat, confessions made after unreasonably long arrest or detention, or confessions otherwise suspected as not having been made voluntarily, shall not be admitted into evidence." (translation emended by the author)). 
evidence. $^{94}$

\section{B. Current Practice}

\section{Investigation: Thorough and Careful}

The postwar reforms might appear to have placed Japan's criminaljustice system squarely within the due-process inodel.

In actual practice this has not been the case. Because the specific language of the Constitution and Code of Criminal Procedure is narrower than the rhetoric of the Occupation inight suggest, and because courts have imterpreted these written provisions narrowly, the current criminal-justice systein in Japan provides wide discretion to the investigative authorities. There is considerable potential for intrusion on personal autonoiny.

The organization of the police force and its unanner of patrolling bring the Japanese police into inuch closer contact with individuals and the commumity than is currently the case in the United States. Although this might in part be an mevitable result of the fact that Japan has far less land than the United States, Japan also has considerably fewer police per capita than does the United States. ${ }^{95}$ What brings the police into closer contact with the community is the stationing of police in local police boxes (köban and chüzaisho) within each neighborhood or town, coupled with regular patrolling through neighborhoods on either foot or bicycle. ${ }^{96} \mathrm{~A}$ considerably higher level of contact also arises froin twice-yearly residential surveys, in which pohce are supposed to visit every residential unit and inquire about such matters as the naine and age of each resident, employment or other activities, automobile ownership, and the like. ${ }^{97}$ This information is kept on file at the pohice box, and nay be used for crimmal investigations (and, presuniably, other purposes as well). ${ }^{98}$ Furthernore, at least in certain areas in Japan, fixed caineras not only regu-

94. Appleton, supra note 89, at 420-23; see 2 SCAP, supra note 89 , at 228-29.

95. According to Keisatsuchō, Keisatsu hakusho [National Police Agency, White PAPER ON POLICE] 303 (1988), there is one police officer for every 555 people in Japan, as coinpared to one for every 354 people in the United States. Given the lower incidence of reported crime in Japan, however, these figures work out to one police officer for every 7.2 crimes reported in Japan and one for every 19.6 crimes reported in the United States. Miyazawa, supra note 2, at 36.

96. See generally AMES, supra note 1, at 17-55 (describing police interaction with coinmunity through a system based on local police boxes); BAYLEY, supra note 1, at 11-51 (saine). Contact between the police and the community is further enhanced by the involvement of community-based groups in crime prevention activities. See id. at 79-97.

97. See AMES, supra note 1, at 37-39; BAYLEY, supra note 1, at 79-82.

98. One of the most benign uses of such information is for giving directions. See AMES, supra note 1 , at $38-39$. 
late traffic ${ }^{99}$ but also provide routine surveillance. ${ }^{100}$ In various ways, therefore, the authorities keep close watch on individuals.

When an individual comes under suspicion of criminal conduct, the authorities have wide discretion to investigate. As mentioned above, among the postwar reforms was the estabhshment of a new set of limits on searches and seizures. ${ }^{101}$ Article Thirty-Five of the Constitution provides that "[t]he right of all persons to be secure in their hoines, papers and effects against entries, searches and seizures shall not be impaired except upon warrant issued for adequate cause and particularly describing the place to be searched and tlimgs to be seized."102 The Code of Criminal Procedure provides for an exception to the warrant requirement for searches incident to arrest. ${ }^{103}$ As interpreted by the courts, searches pursuant to this exception extend quite far. The Supreme Court has upheld the warrantless search of an entire house by four policemen who were waiting for the suspect to arrive home so that they could arrest him. ${ }^{104}$ In the words of the Court, the express language of the Code "requires a connection, in time, between search and seizure on the one hand and the arrest on the other ... [, b]ut which comes first, the search and seizure or the arrest, is not relevant."105

The courts have also limited the reach of the warrant requirement by construing narrowly the concept of a "search." In rather baffling language from one leading case, tle Supreme Court indicated that pohice officers who, acting without a warrant, had unzipped a bowling-ball bag over the objections of the two suspects, had not conducted a search. ${ }^{106}$ Rather, the Court held that such action was permissible as a "measure

99. For a number of years, fixed cameras have been used to detect speeders, a practice the Supreme Court has upheld against a challenge that it infringes on one's "right to likeness." Judgment of Feb. 14, 1986 (Kuroda v. Japan), Saikōsai [Supreme Court], 40 Saikō Saibansho Keiji Hanreishū [Keishū] 48, 49-50 (2d Petty Bench).

100. See Steven R. Weisman, Japan's Urban Underside Erupts, Tarnishing Image of Social Peace, N.Y. TIMES, Oct. 11, 1990, at A1, A10 (reporting that 16 television cameras are mounted over the streets and alleys of Airin, a rundown section of Osaka, moritoring the neighborhood 24 hours a day).

101. See supra note 90 and accompanying text.

102. KENPō [CONSTITUTION] art. 35, para. 1, translated in CONSTITUTIONS OF THE COUNTRIES OF THE WORLD: JAPAN 17 (Albert P. Blaustein \& Gisbert H. Flanz eds. \& T.S.Y. Lee \& Osamu Nishi trans., 1990).

103. See KeIsOHō art. 220(1) (Code of Criminal Procedure, Law No. 131 of 1948), translated in 2 Eibun-Horei-SHA LAw Bulletin SERIES RA-RB, at RA 49 (1988). This exception also embraces searches made during the warrantless arrest of offenders caught in the act of counuitting a crime. Sec KeIsohō art. 220(1) (Code of Criminal Procedure, Law No. 131 of 1948), translated in 2 Eibun-Horei-Sha LAw Bulletin SERIEs RA-RB, at RA 49 (1988).

104. Judgment of June 7, 1961 (Japan v. Arima), Saikōsai [Supreme Court], 15 Keishū 915, 920, translated in Hiroshi ItoH \& LAWRENCE W. BeER, The Constitutional CASE LAW of JAPAN: SELECTED SUPREME COURT Decisions, 1961-70, at 157-61 (1978).

105. Arima, 15 Keishü at 919, translated in ITOH \& BEER, supra note 104, at 159.

106. Judgment of June 30, 1978 (Sakai v. Japan), Saikōsai [Supreme Court], 32 Keishū 670, 674-75 (3d Petty Bench). 
incident to the stop and questioning" of the suspects-who were shortly thereafter arrested for armed bank robbery when the police discovered soine of the stolen money inside the bag. ${ }^{107}$ In another leading case, the Supreme Court took the highly exceptional step of ruling that a police officer who had thrust his hand into the inside pocket of a person suspected of using stimulant drugs had acted illegally. ${ }^{108}$ The Court strongly inplied, however, that the action in question did not constitute a "search." Instead, the Court held it illegal as "a violation of privacy ... similar to a search" that was unreasonable under the circumstances of the case. ${ }^{109}$ Moreover, when investigators seek search warrants, the courts almost always coinply. Out of over 116,000 such warrant requests filed in 1988, the courts rejected only $180 .{ }^{110}$

For Japanese investigators, however, the questioning of suspected criminals is considerably more inportant than searches and seizures. Notwithstanding the elaborate postwar reforms in the area of interrogation and confessions, Japanese police and prosecutors possess broad powers for preindictınent interrogation. ${ }^{111}$ Police inay request individuals to cooperate voluntarily in questioning and to "voluntarily accompany" them to the pohice station for such questioning. As interpreted by the Japanese courts, this police power to suggest voluntary accompaniment inay be quite broad indeed. In the inost extreine reported case to date, the so-called Takanawa Green Mansion Case, four pohice officers met a inurder suspect at his company dormitory one inorning and, without arresting him, asked him to accoinpany them to the police station in their police car. ${ }^{112}$ At the station, officers questioned the suspect throughout that day and late into the evening. ${ }^{113}$ The questioning continued for three inore days; on each of the intervenimg nights, officers placed the suspect in a nearby hotel room where he could be kept under observa-

107. Id. at $675-76$ (translation by the author).

108. Judgment of Sept. 7, 1978 (Japan v. Hashimoto), Saikōsai [Supreme Court], 32 Keishü 1672 (1st Petty Bench).

109. Id. at 1680-81 (emphasis added) (translation by the author). Despite finding the action illegal, the Court did not exclude the evidence the police recovered. Although Hashimoto recognized an exclusionary rule in dictum, that rule is very limited in scope, applying only if there is "such substantial illegality as to negate the spirit of the warrant requirement . . . and it is deemed inappropriate to admit the evidence from the standpoint of deterring future illegal investigations." Id. at 1682-83 (translation by the author).

110. 1988 REPORT OF JUdiclal STATISTICS, supra note 4, at 16-17 (Chart 22). These figures include requests for warrants for searches, seizures, and inspections. In addition to the 180 denials, 880 requests were withdrawn. Id. Even if one assumes that all of those were withdrawn after courts had questioned the grounds for the request, this still means that over $99 \%$ of the requests were granted.

111. For a more detailed discussion of this topic, see Foote, supra note 71.

112. Ruling of Feb. 29, 1984 (Ikuhara v. Japan), Saikōsai [Supreme Court], 38 Keishü 479 (2d Petty Bench).

113. Id. at $482-85$. 
tion. Finally, the suspect's mother came to Tokyo and signed a form asking the police to release her son into her custody. ${ }^{114}$ A divided panel of the Supreme Court concluded that the police had not exceeded the bounds of voluntary accompaniment:

There are elements that may be seen to suggest that the defendant felt that he had no choice but to submit to the long hours of questioning over several days... [but,] on the record, there is no indication that defendant refused the questioning ... nor that he requested or sought to leave the interrogation room or lodging facilities. Nor can we perceive any sign that the investigators compelled the questioning .... [Moreover,] upon considering the concrete circuinstances, including the nature of the case and the need to obtain detailed facts and explanations from the defendant promptly, we find that the investigation was unavoidable from the standpoint of socially accepted views. ${ }^{115}$

When the police have probable cause and choose to arrest a suspect, that arrest will trigger a period of up to twenty-three days that may be utilized in whole or in part for questioning. Under the current Code of Criminal Procedure, the police must decide whether to release or refer a suspect to the prosecutors within forty-eight hours after arrest. ${ }^{116}$ The prosecutors then have another twenty-four hours within which to decide whether to release the suspect or go to court to seek a warrant for the suspect's detention. ${ }^{117}$ The initial detention warrant authorizes detention for ten days; the prosecutors are then entitled to seek a ten-day extension of the detention period before they must decide whether to indict the suspect. ${ }^{118}$ In practice, police refer over $90 \%$ of the suspects they arrest for Penal Code offenses to the prosecutors, and the prosecutors request detention for approximately $85 \%$ of those suspects ${ }^{119}$ (with ten additional days of detention for about one-third of thein). ${ }^{120}$ Under the

114. Id. at 484 .

115. Id. at $486-87$ (emphasis added) (translation by the author). The panel split three to two, but even the two Justices in the minority concurred in the decision to admit the suspect's confession, on the ground that he had reaffirmed the confession during later questioning.

116. KeIsOHō art. 203(1) (Code of Crimimal Procedure, Law No. 131 of 1948), translated in 2 E1BUN-HoRE1-Sha LAW BULlETIN SERIES RA-RB, at RA 44 (1988).

117. KeIsoнö art. 205(1) (Code of Criminal Procedure, Law No. 131 of 1948), translated in 2 EIBUN-HoREI-SHa LAW BULletin SERIES RA-RB, at RA 45 (1988).

118. KeisoHō art. 208(1)-(2) (Code of Criminal Procedure, Law No. 131 of 1948), translated in 2 Eibun-Horei-Sha LAw Bulletin Series RA-RB, at RA 46 (1988). Technically, the judge will allow such an extension only when he "deems that there exists an unavoidable cause." KEISOHō art. 208(2) (Code of Criminal Procedure (Law No. 131, July 10, 1948)), translated in 2 EiBUN-HoreISHa LAW Bulletin Series RA-RB, at RA 46 (1988).

119. WhITE PAPER ON CRIME 1988, supra note 1, at 102 (tbl. III-2) (excluding cases involving professional or gross negligence causing death or bodily injury by traffic accident; figures are for 1988). Many more suspects are referred to the prosecutors without having been arrested. See infra notes $159-67$ and accompanying text.

120. See 114 HöMUSHō, KENSATSU TŌKEI NENPö [MinistRy OF JUSTICE, ANNUAL REPORT of Statistics on Prosecutionl 248-49 (tbl. 34) (1988) (statistics covering suspects for Penal Code and special law offenses). 
Code, prosecutors normally must show a fear of flight or destruction of evidence in order to obtain a detention warrant. ${ }^{121}$ They obviously have little trouble doing so: requests for such warrants (whether for the initial ten days or the extension) are granted over $99.7 \%$ of the time. ${ }^{122}$

Some scholars have argued that, in light of the limited statutory purposes for detention, the detention period should not be used for interrogation. ${ }^{123}$ That position lias never been accepted, however. On the contrary, other statutory language dating from the Occupation reforms expressly contemplates the questioning of suspects who are under arrest or detention. ${ }^{124}$ Prosecutors freely acknowledge their use of the detention period for interrogation, even stating that the key purposes of preindictment detention are "questioning the suspect, demanding a confession, and pursuing other crimes." 125

Under the Code, the suspect has the right to remain silent during questioning and inust be informed of this right. ${ }^{126} \mathrm{~A}$ literal reading of the Code, however, supports the inference that a suspect who is under arrest or detention has no right to leave the interrogation rooin; ${ }^{127}$ and there is no requirement that investigators break off questioning if a suspect asserts the right to silence. In practice, therefore, these standards have resulted in the so-called "duty to submit to questioning"- the duty to sit in the interrogation room and listen to the questions or comments of the investigators-during the period of up to twenty-tliree days while the suspect is under arrest or detention.

Of course investigators do not liave time to question each suspect throughout all that time, but they do consider obtaining a confession to be a vital part of each case. ${ }^{128}$ And they usually succeed: approxinnately

121. See Keisohō art. 60(1) (Code of Criminal Procedure (Law No. 131, July 10, 1948)), translated in 2 EIBUN-HOREI-SHA LAW BULLETIN SERIES RA-RB, at RA 13 (1988).

122. 1988 REPORT OF JUDicial. STATISTICS, supra note 4, at 16-17 (Chart 22).

123. See, eg., Nobuyoshi Araki, Higisha ni wa "torishirabe no jūnin gimu" ga aru ka [Do Suspects Have a "Duty to Submit to Questioning"?] and materials cited therein, in JURISUTo zōKAN, KeiJ SOShōhō no sōten [JuRisuto Extra Number, Issues in Criminal Procedure] 60 (1979).

124. Keisohō art. 198(1) (Code of Criminal Procedure, Law No. 131 of 1948), translated in 2 EibuN-HoRei-Sha LAw Bulletin SERIES RA-RB, at RA 42 to RA 43 (1988).

125. Kensatsu no shomondai (2, kan) (zadankai) [Various Issues Relating to Prosecution (Part 2, Conclusion) (Roundtable Discussion)], 13 HANREI JIHO [HANJI] 1050, 1058 (1961) (statement of Masayoshi Honda, Director, First Research Division, Research and Training Institute, Ministry of Justice) (transiation by the author).

126. KEIsOHō art. 198(2) (Code of Criminal Procedure (Law No. 131, July 10, 1948)), translated in 2 EIBUN-HoREI-Sha LAw Bulletin Series RA-RB, at RA 43 (1988).

127. Article 198(1) of the Code of Criminal Procedure provides that "the suspect may, except in cases where under arrest or detention, refuse to appear, or leave at any time after appearance." KEIsoHō art. 198(1) (Code of Crininal Procedure, Law No. 131 of 1948), translated in 2 EiBunHOREI-SHA LAW BULLETIN SERIES RA-RB, at RA 43 (1988) (translation emended by the author and emphasis added).

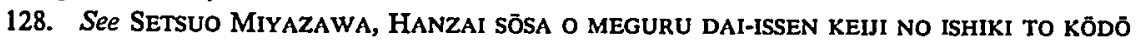


$90 \%$ of Japanese cases involve full confessions, ${ }^{129}$ and in inost of the reinainder the defendant confesses to all but certain elements of the crime (such as intent).

For Japanese investigators, however, obtaining a confession signifies 1nore than just getting the suspect to admit to having committed the crime. It entails obtaining a thorough account of all relevant details of the criine and the personal background and circumstances of the suspect, including possible involveinent in other crimes. Obtaining a confession also ineans getting the suspect to accept inoral responsibility. ${ }^{130}$ Yet despite the importance of confessions, the confession statement itself need not include a verbatim account of the suspect's words. To the contrary, it is a standard and court-approved practice for investigators to prepare summarized confession stateinents following-sometimes long after-the conclusion of one or even several interrogation sessions. These suininarized confession statements typically form the heart of the evidence introduced at trial. ${ }^{131}$ Furthermore, the constitutional and statutory prohibitions on use of involuntary confessions have been construed narrowly. As a practical inatter courts almost always focus their attention on questions concerming the rehability, rather than the voluntariness, of confessions. ${ }^{132}$

Another right strongly proinoted by the Occupation was the right to counsel. In practice, though, the role of defense counsel has proven to be

[The Attitudes and Actions of Front-Line Detectives Concerning the INvestigation OF CRIME] 260-61 (1985) (asserting the police belief in necessity of interrogation and confession), translated in part, supplemented, and updated in SETSUo Mryazawa, Policing IN JAPAN: A STUDY ON MAKING CRIME (Frank G. Bennett, Jr. trans., 1992) [hereinafter MiYAZAWA, Policing IN JAPAN]; Haruo Abe, Police Interrogation Privileges and Limitations Under Foreign Law: Japan, 52 J. CRIM. L. Criminology \& Police SCI. 67, 67-69 (1961) (describing the inportance to criminaljustice authorities of obtainmg a confession from a suspect); Keiji Yonezawa, Higisha no torishirabe [Questioning of Suspects], 537 HANTA 61, 61 (1984) (same).

129. See Miyazawa, supra note 2, at 47.

130. See Masao Tsunakawa, Higisha no torishirabe gijutsu [Techniques for Questioning SuSPECTS] 44-92 (1977); Marcia E. Goodman, The Exercise and Control of Prosecutorial Discretion in Japan, 5 UCLA PAC. BASIN L.J. 16, $48-49$ (1986) (stating the prosecutorial belief in confession as moral cleansing); Akio Harada, Higisha no torishirabe-kensatsu no tachiba kara [Questioning of Suspects-From the Standpoint of the Prosecution], in 1 KEUI TETSUZUKI, supra note 1, at 177, 180-81 (discussing the need to aclieve the acceptance of responsibility during pretrial questioning); Hiroshi Wagatsuma \& Artlur Rosett, The Implications of Apology: Law and Culture in Japan and the United States, 20 LAw \& Soc'Y REv. 461, $481-83$ (1986) (positing apology as an alternative to filing of criminal charges or as an extenuating circumstance at time of punishment).

131. See Masahiro Hiratani, Kyojutsu chōsho no yakuwari-saiban no tachiba kara [The Role of Records of Statements-From the Standpoint of the Judiciary], in 2 KEIJI TETSUZUKI, supra note 1, at 879 (explaining function of records of statements at trial); Kazuo Kawakami, Komento 1 (kensatsu) [Comment 1 (from the Standpoint of the Prosecution)], in 2 KEIJI TETSUzuKI, supra note 1, at 887; Masayoshi Tamura, Komento 2 (bengo) [Comment 2 (from the Standpoint of the Defense)], in 2 KEIJI TETSUZUKI, supra note 1 , at 891 .

132. See Hiroshi TAMIYA, Kenisoshōhō nyūmon [INTroduction to CriminaL Procedure LAW] 204-07 (3d. ed. 1982); Foote, supra note 71. 
quite limited. Counsel are never permitted to attend interrogation sessions. Moreover, even when the suspect has access to and can afford counsel, ${ }^{133}$ the Code of Criminal Procedure permits investigators to impose conditions on ineetings between the suspect and counsel. ${ }^{134}$ Investigators are not shy about using this authority. According to various estimates, ineetings with counsel inay be limited to fifteen minutes once every four or five days in coinplex or difficult cases, and a suspect in detention is unlikely to have inuch opportunity to meet with counsel until the prosecutors have finalized their case. ${ }^{135}$ Fewer than one quarter of defendants are released on bail, ${ }^{136}$ and for the remainder meetings must occur at the detention facility.

The role of the adversary process-and even the formal trial itself remains highly circumscribed. Japan has few lawyers and fewer still who take criminal cases. In the view of inany prosecutors, defense counsel often display low levels of skill and effort. ${ }^{137}$ Froin the standpoint of defense attorneys, the superior strength of the prosecutor's investigative powers can make criminal cases seein hopeless. There is also the perception among defense counsel that contesting cases, rather than simply confessing and showing reinorse, can result in harsher penalties. ${ }^{138}$

Furthermore, despite the Occupation's goals of imvigorating both the adversary process and the trial itself inore along a U.S. model, most Japanese trials in fact are doininated by a written file, prepared not by a preliminary judge but by the prosecutors. The trial consists primarily of

133. The right to appointed counsel for indigents does not attach until indictment. See infra note 313 and accompanying text.

134. Keisohō art. 39(3) (Code of Criminal Procedure (Law No. 131, July 10, 1948)), translated in 2 Elbun-Horei-Sha LAw Bulletin Series RA-RB, at RA 9 (1988).

135. See, e.g., BAYLEY, supra note 1, at 45-46 (pointing to gap between guarantee of right to counsel and police limitations on meetings with counsel); Abe, supra note 128, at 70-71 (describing same); Kazuo Itoh, On Publication of the "Citizens' Human Rights Reports," 20 LAw IN JAPAN 29, 54-61 (1988) (report of Japan Civil Liberties Union on compliance with International Covenant on Human Rights, describing same).

136. See Masayoshi Tamura, Nihon no keiji shihō no tokushoku-bengo no tachiba kara [The Characteristics of Japanese Criminal Justice-From the Standpoint of the Defense], in 1 KEJI TETSUzUKI, supra note 1 , at 26,32 . Tamura further claims that defendants who continue to deny their guilt are highly unlikely to be released on bail. $I d$.

137. See Kawakami, supra note 1, at 16-17; cf. Yoshifusa Nakayama, Nihon no keiji shihō no tokushoku-saiban no tachiba kara [The Characteristics of Japanese Criminal Justice-From the Standpoint of the Judiciary], in 1 KEIJI TETSUzUK1, supra note 1, at 1, 9 (presenting judge's view that, apart from limits on meetings with suspects, defense counsel in Japan are not in significantly worse position than defense counsel in other countries and that, consequently, primary responsibility for achieving balance in adversary process must rest with defense counsel's own efforts).

138. See Tamura, supra note 136, at 30-33. See generally Gendai saiban no kadai kaiketsu o mezashite, Zenkoku saibankan konwakai hōkoku (1), Gödō hōkoku: Jihaku no nin'isei o meguru shomondai [Seeking Solutions to Issues for Today's Trials, Report of the National Gathering of Judges (1), Joint Report: Various Problems Regarding the Voluntariness of Confessions], 1310 HANJI 5, 7-8 (1989) [hereinafter Joint Report] (report of nationwide conference of judges discussing factors accounting for limited role of defense counsel). 
confirming the results of the investigation as reported in this file. ${ }^{139}$ This prosecutorial dominance has led to widespread characterizations of Japan's criminal justice systein as "prosecutorial justice" (kensatsukan shiho) and "trial by dossier" (chosho saiban). ${ }^{140}$ And it is this aspect of Japanese criminal justice in particular that Judge Ishimatsu was focusing on when he asserted that "criminal defendants in Japan do not receive trials by judges." 141 In Ishimatsu's view, "criminal trials . . . are conducted in closed rooins by the investigators, and the proceedings in open court are merely a formal cereinony [to confirm the conclusions of the investigators]." 142

\section{The Crime-Control Model Revisited}

The Japanese criminal-justice system, as it is actually apphed, may thus appear no different from the crime-control model. After all, the Japanese system provides broad tools for "informal administrative factfinding . . . in the early stages of the criminal process" and places great "confidence in the rehability of ... [that] fact-finding." 143 Furthermore, as in the crime-control model, the restrictions on this informal administrative fact-finding are few, consisting for the inost part only of measures regarded as enhancing rehability. For example, although an exclusionary rule has been recognized by the Japanese Supreine Court, ${ }^{144}$ it is closely circumscribed and apphes only in rare cases-which not coincidentally tend to be the very cases in which the courts have concluded that the defendant is innocent. ${ }^{145}$ In addition, as reflected by the limited scope of the adversary systein and the dominant role played by the prosecutor's written file, the prevailing viewpoint seems to accord fully with the criine-control model's position that "subsequent processes, particularly those of a formal adjudicatory nature, are uulikely to produce as reliable fact-finding as the expert administrative process that precedes them is capable of." 146 Finally, the systein produces high rates of appre-

139. See, eg., Hirano, supra note 9, at 409, 419-20; Ishimatsu, supra note 8, at 62-66.

140. See, e.g., Ishimatsu, supra note 8, at 63 ("trial by dossier"); Nakayama, supra note 137, at 2 ("prosecutorial justice").

141. Ishimatsu, supra note 8 , at 62 (translation by the author).

142. Id. (translation by the author).

143. PACKer, supra note 10, at 160-61.

144. Judgment of Sept. 7, 1978 (Japan v. Hashimoto), Saikōsai [Supreme Court], 32 Keishü 1672, 1682-83 (1st Petty Bench); see language quoted supra note 109.

145. See Kōya Matsuo, Bekken taiho to jihaku no kyōyösei [Arrest on a Separate Incident and the Compelled Nature of Confessions], 432 JuRisuto 108, 113 (1969) (careful reading of case in which court disallowed evidence on the basis of procedural violation suggests that court was convinced of defendant's innocence). See generally MASAHITO INOUYE, KEIJI SOSHŌ NI OKERU SHŌKo haljo [The EXClusion of Evidence IN CRIMINAL Procedure] (1985) (surveying various national approaches to exclusion of evidence).

146. PACKER, supra note 10, at 162; see also Hiratani, supra note 131, at 880-82 (describing role of dossier); Kawakami, supra note 131, at 889 (same). 
hension and conviction, just as Packer said it must. ${ }^{147}$

This characterization, however, overlooks several crucial differences between the crime-control model and Japan's criminal-justice system. As noted above, three key attributes of the crime-control model are processing speed, uniformity, and finality. ${ }^{148}$ Speed is a significant consideration in Japan, on which in recent years even greater emphasis has been placed. ${ }^{149}$ Nevertheless, I have seen no indications that speed is regarded as essential for deterrence purposes in Japan, whereas that is its key role in the crimie-control model.

Nor is finality a inajor priority in Japan. ${ }^{150}$ In contrast to the crimecontrol model's position that opportumities for challenge should be strictly limited, the Japanese system (in keeping with its Continental roots) perinits one level of full review of both facts and law on the motion of either the defense or the prosecution. ${ }^{151}$ In addition, either party may also file a second appeal by right. Although the grounds for this second appeal are limited by statute to allegations of constitutional error or conflict with precedent, the Supreme Court on appeal may, at its discretion, inquire into either the law or facts. ${ }^{152}$ On numerous occasions the Supreme Court has reversed and remanded cases after undertaking a searching review of the factual record. ${ }^{153}$ Furthermore, after the appeals process is over, a convict (regardless of whether the sentence has been fully served) and even a convict's heirs may file a petition for a new trial. ${ }^{154}$ Although narrow judicial interpretation of various rights and the broad discretion afforded to investigators can combine to limit the range of legal issues defendants and defense counsel can successfully pur-

147. See supra notes $2-3$ and accompanying text.

148. See supra notes 32-34 and accompanying text.

149. See, e.g., Yoshinobu Iida, Jinsoku saiban to soshō sokushin-saiban no tachiba kara [Speedy Trials and Speeding Up Proceedings-From the Standpoint of the Judiciary], in 2 KEIJI TETSUZUKI, supra note 1, at 497 (analyzing current practice and reform efforts).

150. This is true for serious cases in which the Japanese criminal-justice system provides a formal track of proceedings with multiple opportunities for review. Other tracks make possible much greater speed and finality. Thus, for example, Japanese criminal procedure permits summary disposition of a wide range of offenses with the consent of the defendant. These proceedings are quick and usually final, although both sides retain the right to demand a formal trial if not satisfied with the summary order. Punishment, however, is limited to a minor fine. See SHigemitsu Dando, Japanese Criminal Procedure $494-99$ (1965); Haley, supra note 1, 121-38. Similarly, the informal track of suspended prosecution, described infra at notes 176-98 and accoinpanying text, is both fast and usually final. Suspended prosecution involves no formal punishment at all (although restitution may be an unstated condition). The crime-control model seems inapposite to Japan on this point because when Packer speaks of speed and finality he seeins to have in mind the formal track entailing substantial punishments for serious offenses, as well as lesser sorts of proceedings.

151. See, eg., Supreme Court of JaPAN, OUtLine of Criminal Justice in JaPAN 29-30 (1985).

152. Id. at 30-31.

153. See, e.g., Hirano, supra note 9 , at 422 (citing cases).

154. KEISOHö arts. 435, 439 (Code of Criminal Procedure, Law No. 131 of 1948), translated in 2 Eibun-Horei-Sha LAw Bulletin SERIEs RA-RB, at RA 93 to RA 94, RA 95 (1988). 
sue on appeal, unless a defendant waives these rights, the proceeding does not become final until there have been three levels of judicial review.

For present purposes, however, the most important distinction relates to uniformity. In sharp contrast to Packer's crime-control model, the Japanese criminal-justice system does not seek simply to process cases as quickly as possible according to highly uniform standards and pursuant to routme, stereotyped procedures. The ultimate aim of this system is not merely to attain as many convictions as possible and punish the offenders (primarily by putting them in jail). On the contrary, the Japanese system emphasizes the importance of individualized determinations, based on careful consideration of the individual's personal circumstances and other factors. It places great weight upon achieving rehabilitation and reintegration of the suspect into the cominumity without resort to mcarceration-imdeed, if possible, without the stigma of a conviction or even an arrest.

These priorities in turn reveal a crncial difference between the animating premises of the crime-control inodel and the benevolent-paternalism model. Whereas the former is based almost exclusively on the assumption that the only viable way to suppress crime is general deterrence-sending a inessage to potential offenders that if they commit a crime they will get caught and do time-the latter is based heavily, though not exclusively, on an ethos of specific prevention. Japanese authorities are by no means soft on crime, nor would one characterize their actions as based on "love" for the offender. Yet they have established a system that seeks to maintain order in large part by attempting to reform offenders and reintegrate them into the cominunity. In principle, the system resorts to mcarceration only if rehabilitation is deemed unlikely or, for other reasons such as the gravity of the crime, incarceration is regarded as essential for purposes of general deterrence or to satisfy a cominunity desire for retribution. ${ }^{155}$ This einphasis on specific prevention does not simply coine into play after a conviction. Rather, it affects, if not pervades, every stage of the system. ${ }^{156}$

155. The Japanese authorities might prefer to think of the latter objective as not deprecating the seriousness of the crime, but the retributive message is clear.

156. See, e.g., BRA1THWAITE, supra note 14, at 61-65 (noting Japanese commitment to reintegration of offenders); John O. Haley, Confession, Repentance and Absolution, in MEDIATION AND CRiminal Justice: Victims, OFFENders AND Communities 195, 195 (Martin Wright \& Burt Galaway eds., 1989) (pointing to "second track" in Japanese criminal justice whereby offenders receive leniency in return for confession and repentance). 


\section{Prosecution of Cases: Benevolence at Work}

a. The Police: Bizai Shobun

Japanese police boast one of the highest rates for clearing reported crimes of any system in the world. ${ }^{157}$ Even excluding cases involving professional or gross negligence causing death or bodily injury by traffic accident (all of which were reported as cleared), the 1988 official overall clearance rate for Penal Code offenses was 59.8\%. ${ }^{158}$ Yet police arrested fewer than $20 \%$ of the adult Penal Code suspects they themselves identified. ${ }^{159}$ Does this mean that the police were wrong over $80 \%$ of the time? That there was no more than minimal intrusion on the personal autonoiny of the unarrested $80 \%$ ? Apparently neither.

In Japan, a crime may be treated as cleared even if police have not arrested a suspect for it. Only a relatively sinall percentage of those identified as suspects are later deeined to have had nothing to do with the crime in question, and $80 \%$ of all identified suspects are not arrested. Yet the substantial majority of those not arrested are nevertheless subject to prosecution on what is frequently referred to as an "at-home basis." In other words, these suspects are not arrested and legally have no duty to present themselves to the authorities for questioning, but their cases are sent on to the prosecutors for further proceedings.

Even before referral, however, a substantial minority of the casesnearly $40 \%$ of adult Penal Code offenders in recent years-are closed by the police as petty offenses. ${ }^{160}$ In principle, this option, known as bizai shobun (disposition of trivial crimes), is reserved for a specified list of minor offenses, including assault, theft, fraud, embezzlement, and gambling. ${ }^{161}$ Given the breadth of several of these offenses, police have considerable discretion over what to treat as minor. Suspects in this category are not punished in a formal sense. Yet neither are they cleared from the system free from any consequences whatsoever. On the contrary, pursuant to official investigation standards, if police release a sus-

157. See supra note 2 and accompanying text.

158. White PAPER ON CRIME 1988, supra note 1, at 4 (tbl. 1) (statistic excludes cases involving professional or gross negligence causing death or bodily injury by traffic accident from total figures).

159. This number is derived by dividing the number of persons arrested by police for Penal Code offenses, $i d$. at 102 (tbl. III-2), by the total number of suspects treated as "offenders cleared," id. at 4 (tbl. 1) (excluding from each category suspects in cases involving professional or gross negligencc causing death or bodily injury by traffic accident).

160. See Miyazawa, supra note 2, at 33 (citing to National Police Agency statistics, and excluding cases involving professional or gross negligence causing death or bodily injury by traffic accident). This petty offense category consists only of persons formally identified by the police as "suspects." Even before reaching this stage, police may, of course, choose to overlook matters.

161. There appears to be fairly wide discretion in what to treat as "minor." The list of crimes eligible for this treatment is contained in standards announced by the Public Prosecutor's Office pursuant to article 246 of the Code of Criminal Procedure. For crimes not so designated, that same article requires the police to send all cases they investigate to the public prosecutors. 
pect on the basis of bizai shobun they must take certain steps. Police are required to counsel the suspect sternly and admonish him or her not to commit crimes in the future. ${ }^{162}$ Accordingly, suspects can expect to be questioned carefully and given a lecture by police. They may also be required to sign an apology and pledge not to engage in inappropriate behavior agani. ${ }^{163}$ The investigation standards also instruct police to call in a neniber of the suspect's family, the suspect's eniployer, or some other such responsible individual, counsel that person to keep close watch over the suspect in the future, and even have that person undertake in writing to provide such ongoing supervision. ${ }^{164}$ Finally, police are required to persuade the suspect to provide restitution, to make an apology, or to take other appropriate measures for the victim. ${ }^{165}$ In addition, a record of the bizai shobun will be kept, which presumably will affect decisions on leniency in the event of future wrongdoing.

Thus, for relatively minor crimes in the category of bizai shobun, police have discretion to withhold formal sanctions and avoid substantially disrupting the hife of the suspect. In an effort to deter any future niisbehavior, police nonetlieless seek to impress upon the suspect the gravity of the situation and its potential consequences as a means of deterring any future misbehavior. As a group, police are undoubtedly the most deterrence-minded among criminal-justice authorities in Japan. Yet in landling cases of this sort and in recommending that the prosecutors deal leniently with suspects who have "shown sincere repentance," police give considerable weight to interests of rehabilitation and specific prevention. ${ }^{166}$

There are at least two broad categories of cases in which police decline to arrest a suspect but still refer him to the prosecutors on an athome basis. If police have received a formal complaint of crime froin a victim or other person, the Code of Criminal Procedure requires the

162. Hanzai sōsa kihan, Chikujō kaisetsu [Criminal Investigation Standards, WTrH COMMENTARY ON EACH ARTICLE] art. 197 \& commentary, at 245-46 (Keijikyoku, Keisatsuchō [Criminal Div., Nat'l Police Agency] ed., 1980) [hereinafter CRIMINAL INVESTIGATION STANDARDs]. See generally Minoru Shikita, Integrated Approach to Effective Administration of Criminal and Juvenile Justice, in CRIMINAL JUSTICE IN ASIA: THE QUEST FOR AN INTEGRATED APPROACH 32, 37 (B.J. George, Jr. ed., 1982).

163. CRiminal InVestigation Standards, supra note 162, art. 197(ii), at 245-46. Where no other such responsible person can be found, the commentary instructs police to "take appropriate steps likely to aid in the suspect's rehabilitation." Id. at 246.

164. Id. art. 197(iii), at 245. See generally BAYLEY, supra note 1, at 130-32 (providing examples of offender contrition as centrally important to police disposition of cases); Wagatsuma \& Rosett, supra note 130, at 488-92 (role of formal apology letters (shimatsusho) in reestablishing contact between offender and victim).

165. CRIMinal InVestigation Standards, supra note 162, art. 196, at 244-45.

166. See, e.g., L. Craig Parker, JR., The Japanese Police System Today: An American PerSPective 91-92 (1984); Shikita, supra note 162, at 137. 
police to refer the matter to the prosecutors. ${ }^{167}$ Thus, even if the police feel that a complaint is groundless or that the matter is insignificant they must refer the case to the prosecutors, but in such cases they are unlikely to arrest anyone. Many other at-home referrals fall into a second category, however. These involve relatively serious offenses, with substantial evidence that a particular suspect is guilty. In such cases, even if there has been a formal coinplaint, the pohice may nonetheless conclude that there is no need for a formal arrest if factors such as the nature of the crime and the suspect's personal circumstances so indicate. Again, this does not mean that the suspect is not questioned by the police. On the contrary, this latter category of cases is composed almost entirely of suspects who voluntarily cooperate in the investigation, ${ }^{168}$ and such "voluntary" questioning can be lengthy and intense. But in cases in which they refer suspects to the prosecutors without arresting the suspect, the police are implicitly determining that the interest in maintaining order does not necessitate arrest and that the interest in reforming the suspect would best be served by minimizing disruption in the suspect's life. At least in the case of inoderately serious crime, police almost certainly will take this approach only if the suspect provides a full and apparently sincere confession and displays true reinorse.

The absence of a formal arrest requires further coininent. Although there are otlier, inore severe types of stigma in the Japanese criminaljustice system, I an convinced that arrest is in practice the most important. In part, this reflects the practical consequences: an arrest carries with it the prospect of physical confinement for at least forty-eight hours and potentially much longer. The first such confinement, presumably, lias the greatest psychological and symbolic impact on the individual. More iunportantly, despite the existence of a presumption of innocence under Japanese law, ${ }^{169}$ upon arrest a suspect is widely regarded by the media and the public as gnilty. ${ }^{170}$ The arrest record can also have a significant effect on employment, community attitudes, and other social relations. ${ }^{171}$

167. KEISOHō art. 242 (Code of Criminal Procedure, Law No. 131 of 1948), translated in 2 Eibun-Horei-Sha LAw Bulletin SeRies RA-RB, at RA 54 (1988).

168. Many cases of so-called "voluntary accompaniment" undoubtedly fall into this category, although in the more problematic cases of voluntary accompaniment police proceed to arrest the suspect after the voluntary questioning has provided them with probable cause.

169. See 1 Kōya Matsuo, Keiji soshōhō [Criminal Procedure Law] 210-13 (1979) (discussing role of presumption of innocence in criminal-justice system).

170. This attitude exists in the United States but is far more pronounced in Japan. The Japanese view is presumably linked both to the rather low percentage of suspects who are later dropped from the criminal system for insufficient evidence or similar reasons and to the overwhelming conviction rate. Upon a suspect's arrest the Japanese media will normally drop the appellation san from after that person's name. In addition, photographs of arrested suspects are typically oval-shaped, to distinguish them from photographs of "normal" people.

171. In Japan, as in the United States, the degree of stigma undoubtedly depends considerably 
The powerful stigma of arrest, I believe, helps to explain in part why Japanese courts have been willing to relax greatly the standards for voluntary accompaniment. The courts seem inclined to let police use considerable "persuasion" to convince suspects to consent to accompaniment and questioning, rather than force the police to take the formal and stigmatizing step of arrest. ${ }^{172}$ Other factors, however, provide the primary rationale for the broad license that courts have recognized in the area of voluntary accompaniment. These include great deference to the perceived needs of investigators and, apparently, a feeling that such pohice imtrusions are not unreasonable. In the Takanawa Green Mansion Case, for exainple, the Supreme Court explicitly referred to "the need [for investigators] to obtain detailed facts and explanations from the [suspect] promptly"173 as a major reason for perimitting the four-day "voluntary" accompaniment of the suspect. In many cases where the voluntary accompaniment does not look altogether consensual, however, the pohice appear to have possessed probable cause sufficient to justify an immediate arrest. If the courts declared that questioning in those borderline cases was illegal, the police presumably would inake more arrests. ${ }^{174}$

on the class of the person involved. For some segments of society, most notably the yakuza, arrest may carry little or no stigma.

172. Cf. Schneckloth v. Bustamonte, 412 U.S. 218, 228 (1973) (announcing a broad interpretation of "voluntary" consent to search and stating: "If the search is conducted and proves fruitless, that ... may convince the police that an arrest with its possible stigma and embarrassment is unnecessary, or tliat a far more extensive search pursuant to a warrant is not justified. In short, a search pursuant to cousent may result in considerably less inconvemience for the subject of the search."); Hirano, supra note 9, at 408-09 (stating that Japanese people regard being indicted, even if not detained, as a far greater intrusion and burden than being kept in custody for several days).

Of course, in a voluntary accompaniment of the sort in the Takanawa Green Mansion Case, Ruling of Feb. 29, 1984 (Ikuhara v. Japan), Saikōsai [Supreme Court], 38 Keishū 479 (2d Petty Bench), in which police picked up the suspect at his company dormitory in the presence of his coemployees and questioned him for four full days, the suspect would undoubtedly suffer serious stigma regardless of whether he was formally arrested. The more typical voluntary accompaniment case, with no more than a few hours of questioning, would not normally entail the same stigma.

173. Id. at 487 (translation by the author).

174. In comparison to Japan's officially reported clearance rate of nearly $60 \%$, the clearance rate in the United States is estimated at abont 20\%. See Federal Bureau of INVESTigation, U.S. DEP'T OF JUSTICE, UNIFORM CRIME REPORTS FOR THE UNITED STATES 163 (tbl. 20) (1990) (estimating overall clearance rate at $21.1 \%$ ). Unlike the clearance rate in Japan, however, the rate in the United States is explicitly defined as "clearance by arrest." To be sure, especially in cases involving minor crimes, some American suspects who voluntarily cooperate with the police are let off without an arrest despite evidence of guilt. But the dominant assumption in the United States is that once police have solid evidence against a suspect they will arrest. On balance, the stigma of an arrest might be lessened somewhat in the United States by the fact that arrest applies to a much broader class of suspects, including many whose cases will be dismissed. By the same token, precisely because that stigma attaches to a much broader group of suspects than is the case in Japan, it should be a matter of siguificant concern to American authorities if that stigma and other attendant consequences (most notably time in jail) render rehabilitation and reintegration into the community more difficult. John Braithwaite, for example, developed in some detail the argument 
One further observation is in order. Although the Japanese policy of limiting arrest can avoid stigma for some suspects, the relaxed standards on voluntary accoinpaniment have the further effect of insulating police from constitutional and statutory limitations on arrest and questioning. So long as questioning is "voluntary," the warrant requirements do not come into play, nor does the clock begin to run on the time period for referral to the prosecutors. This presents one of the major due-process concerns arising out of Japan's benevolent paternalism, a theme to which I will return. ${ }^{175}$

\section{b. The Prosecutors: Suspension of Prosecution}

At the next stage of the criminal process, prosecutors have broad discretion over both investigation and disposition of cases. The prosecutors can and, for suspects who have been arrested, usually do seek warrants for at least ten days of detention. As noted earher, prosecutors request detention for about $85 \%$ of the arrestees referred to thein and, across nearly every category of warrants, such requests are granted over $99 \%$ of the time. ${ }^{176}$ In addition, for those suspects referred to the prosecutors on an at-home basis, cooperation remains the rule. ${ }^{177}$

Although prosecutors mvestigate other evidence and question other witnesses, ${ }^{178}$ the centerpiece of the investigation is ordinarily the interrogation of the suspect. During this interrogation, the investigators seek to gather all relevant details of the crime. In addition, however, they carefully explore the suspect's inotives, family background and other personal circuinstances, and involveinent in any other crimes. As should be apparent from its breadth, imterrogation plays a major role not only in proving the crime but also im determining the manner in which the prosecutors will treat the suspect. Moreover, the authorities regard close oneon-one questioning as their most important tool for leading suspects to accept full inoral responsibility for their misdeeds and for setting thein on the road to rehabilitation. ${ }^{179}$

that stigmatization can foster increased criminal behavior. See BralthwaITE, supra note 14, passim.

175. See infra notes $284-332$ and accompanying text. For an example of the use of voluntary accompaniment in place of arrest and discussion of the due-process concerns raised thereby, see MiYazawa, Policing IN JAPan, supra note 128, at 54-57.

176. See supra notes $119-22$ and accompanying text.

177. For those suspects whom police decided not to arrest despite the existencc of sufficient evidence, failure to cooperate could, after all, result in arrest and detention.

178. Defense counsel are not present at these witness-questioning sessions. At the end of the questioning, prosecutors prepare a summarized version of the witness' responses, which the witness then acknowledges. Despite the hearsay rules, these summaries generally are admitted either as a substitute for or in addition to in-court testimony, under exceptions that have been broadly interpreted. See, e.g., Hiratani, supra note 131, at 883-85 (detailing exceptions).

179. See, e.g., sources cited supra at note 130. Even some of those who have been most critical of the current criminal-justice system have acknowledged this as a benefit of the questioning 
In addition, prosecutors normally interview the victim or the victim's heirs not just for evidence relating to the crime but also regarding such matters as restitution and the victim's feeling toward the suspect. ${ }^{180}$ The prosecutors may also obtain information about the suspect's character and background from the suspect's family and employer and from other nienibers of the community.

All of this information is relevant to prosecutors in determining how to dispose of cases, a determination that is heavily influenced by the goal of specific prevention. Approximately $6.5 \%$ of suspects referred to the prosecutors for nontraffic-related Penal Code offenses are not prosecuted because of insufficient evidence or other weaknesses in the prosecution's case. $^{181}$ A soinewhat larger group of nontraffic-related Penal Code offenses, approximately $15 \%$, is closed through uncontested summary proceedings - not available for major crimes ${ }^{182}$ - $m$ which the niaximum penalty is a fine of 200,000 (about $\$ 1500$ at current exchange rates). ${ }^{183}$

A niuch larger group of suspects, covering the entire spectrum of crininal behavior, falls into the "suspension of prosecution" category. ${ }^{184}$ The doctrime of suspension of prosecution has existed since the 1880 s and was formalized by statute ni $1922 .{ }^{185}$ It expressly permits prosecutors to refrain froni prosecuting a case about which they conclude that, despite solid evidence of guilt, prosecution would not be in the interests of justice. Although suspension of prosecution initially was used only for ininor crimes, nil niuch the same nianner as bizai shobun today, by around 1900 prosecutors had begun to use the system for niore serious

practices. See, e.g., Hirano, supra note 9, at 415 (asserting that the offender's expression of regret elicited by continuous questioning plays a meaningful role in criminal justice); Ishimatsu, supra note 8 , at 67 (stating that the offender's self-reflection brought about by the questioning is effective in preventing repeat offenses).

180. See Goodman, supra note 130, at 26 n.44; Haley, supra note 156, at 199-201.

181. See 1989 HANZAI HAKUSHO, supra note 3, at 106.

182. Article 461 of the Code of Criminal Proeedure makes summary proceedings available to the Petty Courts for cases within their jurisdiction, KEISOHō art. 461 (Code of Criminal Procedure, Law No. 131 of 1948), translated in 2 EIBUN-HoREI-SHA LAw Bulletin SERIES RA-RB, at RA 99 (1988); article 33 of the Courts Law limits the jurisdiction of those courts to minor crimes, primarily those for which the penalty is at most a fine, SAIBANSHowō [CouRTs LAw] art. 33 (Law No. 59 of 1947).

183. See Whire PAPER ON CRIME 1988, supra note 1, at 104 (tbl. III-5); see also Haley, supra note 156, at 197 (explaining the role of summary proceedings in conjunction with suspension of prosecution).

184. Suspension of prosecution is authorized by article 248 of the Code of Criminal Procedure. See KeIsoHō art. 248 (Code of Crimmal Procedure, Law No. 131 of 1948), translated in 2 EIBUNHOREI-ShA LAW BUlletin SERIEs RA-RB, at RA 55 (1988). For discussions of the suspensionof-prosecution doctrine, see Dando, supra note 24; B.J. George, Jr., Discretionary Authority of Public Prosecutors in Japan, 17 LAw IN JAPAN 42, 56-60 (1984); Goodman, supra note 130.

185. Code of Criminal Procedure of 1922 art. 279 (Law No. 75 of 1922); see Dando, supra note 24, at 519-20; Goodinan, supra note 130, at 23; Tashiro, supra note 79; Noriharu Tashiro, Kiso yūyo seido no konnichiteki kadai [Current Issues Concerning the System of Suspension of Prosecution] (pt. 2), 712 KEISATSU KENKYŪ 23 (1989). 
crimes. ${ }^{186}$

As the suspension-of-prosecution doctrine has been interpreted and applied since early in this century, moreover, the emphasis has been squarely on seeking to reform offenders and ensure their reintegration into the community. The doctrine seeks to obviate the stigma of indictment and conviction and the potentially detrimental impact of incarceration. In a 1914 speech before a gathering of police leaders, Procurator General Hiranuma emphasized just these points in urging widespread use of suspension of prosecution:

When one can achieve success through chastising, exhorting good behavior and adinonishing against wrongdoing (yōchō kankai), without taking the step of imposing punishment, it is appropriate to do so. It is a mistake to say that punishment inust be inposed on all offenders. Therefore, I behieve that we inust adopt the policy of expanding the scope of suspension of prosecution as broadly as possible, thereby reducing the number of persons with prior convictions. Soine people say that the use of suspended prosecutions is for the purpose of reducing the number of prisoners and thereby cutting down on expenses. That is one benefit, but it is by no ineans the primary purpose of suspension of prosecution. Persons with prior convictions are likely to fall into despair; and for a person who has entered prison it is difficult to becoine a law-abiding person again following release. ... This is not only extremely sad for the individual in question ... but also represents a very great loss for society as a whole. Protecting against losses of this sort is the inore inportant reason for use of suspension of prosecution. ${ }^{187}$

This einphasis on specific prevention remams a central element of suspended prosecutions. A recent study by five Ministry of Justice researchers characterized suspension of prosecution in the following way:

Recently, "avoidance of labelling" is frequently cited as one of the reasons, froin the standpoint of criminal justice policy, for suspended prosecutions. Yet the avoidance of labelling simply follows froin the guiding principle of suspension of prosecution. Prosecutions are not suspended in order to avoid labelling. Rather, the avoidance of labelling occurs as a consequence of suspending prosecutions for the purpose of rehabilitating offenders. ${ }^{188}$

In analyzing the goals of this system, the authors concluded:

186. See Dando, supra note 24 , at 519.

187. Speech of Procurator General Hiranuma (1914), in Tashiro, supra note 79, at 25-26 (translation by the author).

188. Takeo Momose et al., Sengo (genkō keiso shikōgo) ni okeru kiso yūyo seido un'yō no jittai to kiso yuyosha no saihan [Study on the Actual Administration of the System of Suspended Prosecution after World War II (Following the Enactment of the Current Code of Criminal Procedure) and Recidivism by Those Whose Prosecution Was Suspended], in Hōmu sōGō KeNKyūsho, Hōmushō, 29 HŌMU SŌGŌ KENKYŨSHO KENKYŪBU KIYŌ [RESEARCH AND TRAINING INSTITUTE, MINISTRY of Justice, Bulletin 29 of the Criminological Research Department] 1, 7 (1986) (translation by the author). 
Japanese prosecutors have two primary missions. One is that of the strict prosecutor who does not let the evil sleep and who cries along with the victims. The other is that of the prosecutor who devotes efforts to the reform of offenders so that they will not return to crime, a role that at times entails crying along with the offenders. ... Suspension of prosecution is a key tool for prosecutors in achieving this [latter] mission. ${ }^{189}$

Factors influencing prosecutors in the decision whether to suspend prosecution include the character and personal circuinstances of the suspect, prior criminal record, age, family situation, and einployinent status; remorse and acceptance of responsibility; restitution to the victim; the views of the victim; and the gravity of the crime. ${ }^{190}$ The suspect's chances of obtaining suspension of prosecution can be enhanced by statements from family, employers, or even other members of the commumity demonstrating that support will be available to the suspect.

Some of these factors, in particular the attention paid to the gravity of the crime, ${ }^{191}$ reflect general deterrence concerns. Certain crimes are regarded as so serious that prosecution is essential in order to send a message to other potential offenders and to society in general, although highly mitigating circumstances can still result in suspension of prosecution. Other factors, including the role played by the views of the victim, reflect a retributive function, ${ }^{192}$ although forgiveness by the victim can also be seen as playing an important reintegrative and restorative function. ${ }^{193}$ Yet specific prevention, which hes at the heart of Japan's benevolent paternalism, is by far the dommant objective of the suspension-ofprosecution doctrine.

Suspension of prosecution promotes specific prevention in a number of ways. Although a suspension of prosecution will normally terminate prosecution for the crime in question, ${ }^{194}$ without any exphcit conditions

189. Id. at 21 (translation by the author).

190. See Goodman, supra note 130, at 26-29, 36-46; Momose et al., supra note 188, at 2-3.

191. When the suspension-of-prosecution system was first formally codified in 1922, the gravity of the crime was deliberately onitted from the factors to be taken into consideration in order to make clear that suspension of prosecution could be used for even serious offenses. That factor was added to the statute in the postwar revision of the Code at the suggestion of the Occupation Forces. See Dando, supra note 24, at 520-21.

192. I have been told, however, that if prosecutors feel a victim is being unreasonable in withholding forgiveness from a truly remorseful suspect who has made appropriate restitution, they would not give great weight to that retributive attitude. Conversation with Haruki Sugiyama, Tokyo District Public Prosecutor's Office, im Seattle, Wash. (Dec. 3, 1990).

193. See, e.g., Haley, supra note 156, at 207-08 (stating that the "emphasis on victim compensation and pardon reduces societal demands for revenge and retribution and thus facilitates efforts by law enforccment authorities to provide effective means for offender rehabilitation"); Wagatsuma \& Rosett, supra note 130, at 477-78 (stating that forgiveness in response to apology restores harmony).

194. No published statistics track the reinstatement of suspended prosecutions as a separate category. Rather, published statistics on reinstated prosecutions include both reinstatement of suspended prosecutions and reinstatement of prosecutions instituted but later withdrawn (for 
placed upon it, as a practical matter preconditions may include remorse, the existence of solid family relationships, and secure employment or other evidence of support mechanisms-all factors that might help protect against renewed offenses. As a positive mechanism to guard against recidivism, a government-financed system exists to provide limited financial assistance and aid in obtainmg housing, education, and employment for suspects whose prosecutions have been suspended. ${ }^{195}$ An implicit negative sanction also exists to help deter misconduct by suspects whose prosecution has been suspended: suspension of prosecution is regarded as a first bite at the apple of leniency, justifying harsher penalties in the event of subsequent wrongdoing. ${ }^{196}$

Although the suspension-of-prosecution doctrine bears similarities to the "diversion" programs utilized in a number of jurisdictions in the United States, unlike most such programs, the grant of suspension of prosecution is not expressly made subject to performance of specified actions. ${ }^{197}$ More importantly, suspension of prosecution is not regarded as special, isolated, or experimental in nature. To the contrary, it is a firmly estabhished, nationwide program utilized as a key component of the criminal-justice system. In 1988, suspension of prosecution was granted to nearly two out of every five adult Penal Code suspects referred to prosecutors; nearly half of theft suspects and even $6 \%$ of the murder suspects were granted suspensions. ${ }^{198}$

reasons such as the flight of the defendant or a key witness). Prosecutors have told me that reinstatement of previously withdrawn prosecutions constitutes the great majority of all reinstated prosecutions; in 1988 all reinstated prosecutions totalled 3850, see HöMUSHō, supra note 120 , at 14 (tbl. 6).

195. The system is voluntary and apparently little used. In 1984, only about 1100 out of over 200,000 suspects whose prosecutions had been suspended obtained aid under this program, which was established pursuant to the KōsEI KINKYŨ HOGOHō [REHABILITATION URGENT Protection LAw] (Law No. 203 of 1950). See Momose et al., supra note 188, at 7-9.

196. See Goodman, supra note 130, at 46. A prior suspended prosecution does not necessarily mean that evidence of a subsequent offense will result in prosecution. Indeed, even previous convictions do not rule out the possibihity of suspended prosecutions. Over one quarter of all suspects whose prosecutions are suspended have prior convictions. HōmUSHō, supra note 120, at 314-15 (tbl. 42).

197. See generally B.J. George, Jr., Screening, Diversion and Mediation in the United States, 29 N.Y.L. SCH. L. REV. 1, 14-20 (1984) (stating that in the United States, the offender's "counterpart performance" is part of the "diversion agrecment").

198. 1989 HANZAI HAKUSHO, supra note 3, at 372-73 (tbl. IV-22). The exact 1988 figure for suspended prosecution of Penal Code offenses-excluding cases involving professional or gross negligence causing death or bodily injury by traffic accident-was $37.8 \%$. The high percentage of suspended prosecutions has been a characteristic feature of Japanese criminal justice throughout most of this century. The rate of suspended prosecutions easily topped $50 \%$ during much of the period through the end of World War II and has ranged between $35 \%$ and $40 \%$ for the past 25 years. See id.; see also Dando, supra note 24, at 526-27 (providing five-year averages of cases of suspended prosecution from 1918 through 1968 for all types of offenses). 


\section{c. Trials: Suspended Sentences and Short Sentences}

Approximately $40 \%^{199}$ of the adult Penal Code suspects referred to prosecutors go to full trial. ${ }^{200}$ Given the conviction rate of over $99.8 \%$, virtually all of them can expect to be convicted. This does not mean that considerations of specific prevention, including rehabilitation, are at an end, however, or that the judgments of prosecutors no longer play a role.

The Penal Code and other statutes specify very broad sentencing ranges. The range for murder, for example, is froin three years to twenty years, or life, or the death penalty. ${ }^{201}$ If extenuating circumstances are found, courts can reduce the minimum sentence by half. ${ }^{202}$ Moreover, for those who have not been imprisoned within the past five years, sentences of up to three years inay be suspended. ${ }^{203}$ Given the ability to halve the minimum sentences for extenuating circumstances, sentences can be suspended for all but a very small handful of crimes. ${ }^{204}$

199. See HōmUshō, supra note 120, at IV (tbl. 9), V (tbl. 11). The percentages are derived by multiplying indictment rate by rate for full trials for Penal Code offenders, excluding cases involving professional or gross negligence causing deatl or bodily injury by traffic accident.

200. This does not necessarily mean that the trials are contested. Summary proceedings are available only for minor crimes, and the guilty plea as such does not exist in Japan. Moreover, confessions unust be supported by at least some corroborating evidence. KENPō [CONSTITUTION] art. 38, para. 3, translated in CONSTITUTIONS OF THE COUNTRIES OF THE WORLD: JAPAN 18 (Albert P. Blaustein \& Gisbert H. Flanz eds. \& T.S.Y. Lee \& Osamu Nishi trans., 1990); KeisoHō art. 319(2) (Code of Criminal Procedure, Law No. 131 of 1948), translated in 2 E1BuN-Horel-SHA LAW BULLETIN SERIES RA-RB, at RA 69 (1988). In practice, however, defendants in the great majority of cases consent to all of the evidence prepared by the prosecutors and do not contest the charges.

201. KeiHô arts. 199, 12(1), 14 (Penal Code, Law No. 45 of 1907), translated in 2 EibuNHorei-SHa LAW BUlletin SERIES PA-PC, at PA 40 ("A person who kills another shall be punished witl death or penal servitude for life or not less than three years." (translation emended by the autlor)), PA 4 ("Penal servitude shall be either for life or for a limited term; a limited term of penal servitude slaall vary from one month to fifteen years."), PA 4 ("When augmentation is to be made in penal servitude for a limited term or imprisonment for a limited term, each may be extended to twenty years. When a reduction is to be made therein, each may be reduced to one month or less.") (1988).

202. KeiHō art. 68 (Penal Code, Law No. 45 of 1907), translated in 2 EIBUN-HorEi-Sha LAW Bulletin Series PA-PC, at PA 15 to PA 16 (1988). Pursuant to article 68, deatl penalties may be reduced to not less thian 10 years forced labor, KEIHō art. 68(i) (Penal Code, Law No. 45 of 1907), translated in 2 EIBUN-Horei-Sha LAW Bulletin Series PA-PC, at PA 16 (1988), and life sentences may be reduced to not less than seven years imprisonment, KeIHŌ art. 68(ii) (Penal Code, Law No. 45 of 1907), translated in 2 Eibun-Horei-SHA LAw Bulletin SERIES PA-PC, at PA 16 (1988).

203. KeIrō art. 25(1)(ii) (Penal Code, Law No. 45 of 1907), translated in 2 EIBUN-HoREI-SHA LAw Bulletin Series PA-PC, at PA 7 (1988).

204. Keirō art. 240 (Penal Code, Law No. 45 of 1907), translated in 2 Eibun-HoRei-ShA LAw Bulletin SERIEs PA-PC, at PA 49 (1988). This has led to proposals to reduce the minimum term for robbery resulting in injury from the current seven years to six, thereby qualifing robberyresulting-in-injury prosecutions for suspension if extenuating circumstances were found. This las also led courts to interpret the elements of that crime very strictly in some cases, in order to find some lesser offense. See Tadahiro Tanizawa, Sentencing Standards in Japan, in UNited Nations and Far East INST. For the Prevention of Crime and the Treatment of Offenders (UNAFEI), UNAFEI RESOURCE MATERIAL SERIES No. 16, at 197, 202-03 (1979). 
Within these broad statutory ranges, the determination of sentences is left to the discretion of the courts. Prosecutors file sentence requests, however, which are usually accorded considerable weight. In addition, fairly clear sentencing standards for major classes of crime have developed through internal judicial practice. ${ }^{205}$ Not surprisingly, considerations of specific prevention heavily mfluence those standards.

Such considerations appear to play an especially strong role for courts deciding whether to suspend a sentence. The history of the suspended-sentence doctrine bears striking similarities to that of suspended prosecution. When it was first introduced in 1905, the system of suspended sentences was intended to elimmate problems associated with short-terin confinement, presumably including both overcrowding of facilities and the potentially corrupting influence of hardened criminals on inmor offenders. ${ }^{206}$ Over time, however, the system progressively came to be used for exphicitly rehabihtative purposes; it was expanded to cover a broader range of crimes and began to be utilized much more frequently. ${ }^{207}$

In addition such factors as family relationships, working habits, assurances froin sureties and employers, and type of friends play an important role in determining whether sentences are suspended. ${ }^{208}$ The attitude of the defendant at trial also carries great weight: a sincere confession evidencing acceptance of inoral responsibihty and the sincere desire to reform is crucially important. ${ }^{209}$ Although under the Constitution and the Code of Criminal Procedure the defendant has the right not

205. See Eiji Matsunaga \& Hiroyuki Yoshida, Gōtō chishi jiken ni miru ryökei inshi no sūryöka [Quantification of Sentencing Factors as Seen in Cases of Causing Death in the Course of Robbery], in 31 HōMU Sōgō KENKYŪSHO, HöMUSHō, KENKYŪBU KIYō, KEUI SEISAKU KENKYū [RESEARCH and Training institute, Ministry of Justice, Bulletin of the Criminological Research Department, CRime Policy Research] 23, 48 (1988) (commenting on existence of a "market price" for sentences). The career judiciary, regular transfers of judges, and right of both parties to appeal the sentence as improper presumably all have helped bring about a market price. See Momose et al., Satsujin oyobi gōtō chishi jiken ni miru ryökei no hensen to chiikikan kakusa [Trends and Regional Differences in Sentencing as Seen in Cases of Murder and Causing Death in the Course of Robbery], 30 HōMU sōgō KENKYŪSHO, HōMUSHō, KENKYŪBU KIYō [RESEARCH AND Training Institute, Ministry of JUstice, Bulletin of THE CRIMINological Research DEPARTMENT] 1 (1987); Tanizawa, supra note 204, at 200-04 (describing studies of suspended sentences in bodily injury and theft cases).

206. See Minoru Shikita, Shihöteki shogü no henbö to jïyükei [Transformations in Treatment in the Justice System and Incarceration], in 1 NiHON NO KYõsEI TO HOGO [CORRECTIONS AND Protection in JAPAN] 76, 79-80 (Kyōichi Asakura et al. eds., 1980).

207. Id.

208. See Tanizawa, supra note 204, at 200-04 (describing studies of suspended sentences in bodily injury and theft cases).

209. See, e.g., Hideo Suzuki, Gödö hōkoku-keïi jihaku jiken no shinri to hanketsu [Joint Report-Review and Judgment of Criminal Confession Cases], in Yori yoki shihō no jitsugen no tame ni, Zenkoku saibankan konwakai hokoku (I) [For the Realization of Improved Justice, Report of National Gathering of Judges (Part 1)], 1065 HANJ 3, 18-19 (1983) (criticizing this tendency). 
to testify at trial, ${ }^{210}$ judges clearly expect defendants will testify. Also because the factfinding and sentencing phases are merged into a single proceeding, a defendant who does not testify at trial and who is subsequently convicted cannot then confess at the sentencing stage. ${ }^{211}$ When suspects do testify, an attitude of true remorse may result in a highter sentence, whereas continued demals and a refusal to take responsibility are likely to result in harsher treatment. This outcoine is based on the view that a sincere confession and acceptance of moral responsibility are essential elennents $i m$ the reformation of the offender. ${ }^{212}$

Thus, prosecutors who recommend and judges who issue suspended sentences appear to place great weight on prospects for reintegration into the commumity and rehabilitation. In most cases, the person who has received a suspended sentence is not placed under the supervision of a probation officer. ${ }^{213}$ No special conditions are attached to the suspended sentence, although conviction for another crime during the period of the suspension will result in its revocation. ${ }^{214}$ For defendants who are deemed to need further assistance in rehabilitation but for whoin incarceration is regarded as unnecessary or potentially counterproductive, the court may take the intermediate step of imposing a suspended sentence subject to protective supervision. ${ }^{215}$ Even im this situation, the only formal conditions attached to the probation require that the offender avoid future misconduct and notify the probation officer of place of residence, as well as any changes in that place of residence and any long trips. ${ }^{216}$ In addition, a volunteer probation officer and, when necessary, a professional probation officer are supposed to maintain regular contact with the offender and aid in reintegration. ${ }^{217}$

Suspended sentences are widely utilized in Japan. Nearly $60 \%$ of adults convicted of Penal Code offenses are granted suspended

210. KENPŌ [CONSTITUTION] art. 38, para. $1{ }^{\circ}$, translated in CoNSTITUTIONS OF THE COUNTRIES OF THE WORLD: JAPAN 17 (Albert P. Blaustein \& Gisbert H. Flanz eds. \& T.S.Y. Lee \& Osamu Nishi trans., 1990); KeIsohō art. 291(2) (Code of Criminal Procedure, Law No. 131 of 1948), translated in 2 EiBun-Horei-SHA LAw BULletin SERIEs RA-RB, at RA 63 (1988). Moreover, the defendant is not subject to prosecution for perjury at trial. See Haruo Abe, The Privilege Against Self-Incrimination Under Foreign Law: Japan, 51 J. CRIM. L. CRIMiNoloay \& PoliCe SCI. 178, 180 (1960). .

211. Tamura, supra note 136, at 31-32.

212. See John O. Haley, Sheathing the Sword of Justice in Japan: An Essay on Law Without Sanctions, 8 J. JAPANESE STUD. 265, 271-72 (1982); Tamura, supra note 136, at 31-32.

213. See Rehabilttation Bureau, Ministry of Justice, Community-Based Treatment OF OFFENDERS IN JAPAN 27 (1985).

214. KEIHŌ arts. 25-2(1), 26 (Penal Code, Law No. 45 of 1907), translated in 2 EIBUN-HOREISha LAW Bulletin Series PA-PC, at PA 7, PA 8 (1988); see Rehabilitation Bureau, MINISTRY OF JUSTICE, supra note 213, at 34-35 (discussing conditions of probation and parole).

215. Keirō art. 25-2(1) (Penal Code, Law No. 45 of 1907), translated in 2 EIBUN-HOREI-SHA Law Bulletin Series PA-PC, at PA 7 (1988).

216. See Rehabilitation Bureau, Ministry of JUstice, supra note 213, at 35-36.

217. See $i d$. at 36-38 (detailing the supervision processes). 
sentences. ${ }^{218}$ Of that total, fewer than $15 \%$ are placed under supervision; the remainder need not report to any probation officer. ${ }^{219}$ Apart from having gone through the additional steps of indictment, trial, and conviction, this group might appear to be in a similar position to those whose prosecutions have been suspended; indeed, the same factors influence each decision. ${ }^{220}$ One important reason for deciding to prosecute and then to recommend a suspended sentence stems from general deterrence and retribution: some crimes are so grave that it is regarded as essential to prosecute formally in order to deter others and reaffirm the community sense of seriousness. The suspended sentence has a further role in specific deterrence. Unlike the vague "first bite at the apple" aspect of suspended prosecution, the consequence of a subsequent violation by one on a suspended sentence is clear: incarceration. ${ }^{221}$

The second key aspect of sentencing is, of course, the term of the sentence itself. Here, too, courts appear to place considerable weight on rehabilitative goals. This is reflected primarily in relatively short sentences. The great majority of those entering prison in 1988 received sentences of two years or less. ${ }^{22}$ As one might expect, multiple-repeat offenders-those who had been in prison nine or more times beforereceived, on balance, the longest sentences, but nearly $65 \%$ of even that group received terms of no more than two years. ${ }^{223}$ At the other end of the spectrum, out of nearly 17,000 offenders sentenced to actual time in prison for Penal Code offenses in 1988, only eighty-four were sentenced to terms of over fifteen years. ${ }^{224}$ Virtually all offenders receiving the longer sentences were convicted of murder or felony nuurder, yet even for

218. See id. at 27; see also WhITE PAPER ON CRIME 1988, supra note 1, at 108 (fig. III-2) (distinguishing between suspended sentences for offenders imprisoned with forced labor and without forced labor).

219. See White PAPER on Crime 1988, supra note 1, at 109 (tbl. III-11).

220. See generally Tashiro, supra note 185 at 37-38 (exploring relationship between systems of suspended sentence and suspended prosecution).

221. See KEIHō art. 26 (Penal Code, Law No. 45 of 1907) (revocation of decree suspending execution of sentence), translated in 2 EIBUN-HOREI-SHA LAW BULLETIN SERIES PA-PC, at PA 8 (1988). There are exceptions even to this rule. If the subsequent crime leads only to a fine, the court has discretion whether to reinstate the earlier sentence. See KElHō art. 26-2(i) (Penal Code, Law No. 45 of 1907) (revoking decree suspending execution of sentence), translated in 2 ElBUN-HoREISha LAW Bulletin SERies PA-PC, at PA 8 (1988). Even if the sentence for the subsequent crime is imprisonment, if the court suspends that subsequent sentence it may also leave the original sentence suspended. See KEIHō art. 26(1) (Penal Code, Law No. 45 of 1907) (revoking decree suspending execution of sentence), translated in 2 EIBUN-HOREI-SHA LAW BULLETIN SERIES PAPC, at PA 8 (1988). In any event, if the suspended sentence was only a fine, rcinstatement of that sentence will only mean imposition of that fine.

222. 1 HōMUSHō, DAI-90 KYōSEI TōKEI NENPō, SHōWA 63-NEN [MINISTRY OF JUSTICE, Ninetieth ANNUAL RePort OF Statistics ON CORRECTIONS-1988] 80 (tbl. 20) (1989).

223. Id.

224. Id. at 66-67 (tbl. 15). 
those categories the average sentence was well under ten years. ${ }^{225}$

The key focus in Japan is on keeping individuals out of prison in the first place. After going through successive screenings based to a greater or lesser extent on the individual characteristics of the suspect, fewer than $5 \%$ of the adults originally identified as suspects actually serve time in prison. ${ }^{226}$ For that $5 \%$, studies have suggested that the determination of sentencing length is influenced inost heavily not by the defendant's personal characteristics but by the nature and gravity of the crime itself. ${ }^{227}$ This in turn suggests that criminal justice in Japan does not concern itself solely with specific prevention. In the case of crimes above a certain level, and when dealing with offenders deemed to have advanced criminal tendencies, general deterrence and retribution become highly relevant. Nonetheless, judges also take rehabilitation into account in determining the length of sentences. One judge, discussing the trend throughout much of the period since World War II toward progressively lighter sentences for inany crimes, reinarked that Japanese judges "tend to give inore lenient sentences so that defendants would be impressed with the generosity and thus encouraged to rehabilitate themselves."228

Sentencing occurs within a rather narrow spectrum. With the sentences as low as they are, any term over ten years seeins long indeed; less than $1 \%$ of all prisoners receive-inuch less serve-terms of over ten years. $^{229}$ For all but the inost serious offenses and inost hardened criminals, the objective is to get offenders, even multiple-repeat offenders, out of prison and back into the commumity quickly. The notion that deterrence requires sentences of 50, 150, even 600 years is simply unfathoniable (nor are such sentences even possible under the Penal Code). ${ }^{230}$

225. Id.

226. See supra note 4 and accompanying text.

227. See Tanizawa, supra note 204, at 198-203 (evaluating sentences imposed in cases of theft and bodily injury). This conclusion would seem to be supported by figures showing that the sentences for those entering prison for the first time are only modestly lower than the sentences for repeat offenders. See 1 HōmusHō, supra note 222, at 80 (tbl. 20).

228. Tanizawa, supra note 204, at 203-04.

229. See 1 HōmUSHō, supra note 222, at 80 (tbl. 20). For a description of the parole process, see infra notes 246-58 and accompanying text.

230. The maximum fixed term that may be imposed for any single crime in Japan is 20 years. See KeIHō arts. 12-14 (Penal Code, Law No. 45 of 1907), translated in 2 ElBuN-HoREI-Sha LAW BULLETIN SERIES PA-PC, at PA 4 (1988). If the same offender is convicted of multiple crimes, the total sentence for all the crimes combined may only be $50 \%$ longer than the maximum sentence for the most serious of those crimes (that is, an absolute maximum of 30 years). KEIHô arts. 45-47 (Penal Code, Law No. 45 of 1907), translated in 2 Eibun-HoreI-Sha LAw BulletiN SERIES PAPC, at PA 12 to PA 13 (1988). In the event of a death penalty or life sentence, the only additional penalties that may be imposed are confiscation, for the former, and confiscation and fines, for the latter. KeIHō art. 46 (Penal Code, Law No. 45 of 1907), translated in 2 EIBUN-HOREI-SHA LAw BULLETIN SERIES PA-PC, at PA 12 (1988). These provisions appear to refiect a rehabilitative attitude, based on the view that the offender is being rehabilitated for all crimes at the same time. 
The most notable exception to this sentencing approach is the death penalty, which still exists in Japan but use of which has declined sharply over the past century. The number of executions has dropped from over 500 per year in the early Meiji era to an average of about 25 per year as late as the 1950s, and to an average of only 2 per year over the past five years. ${ }^{231}$ In one sense, the death penalty is simply the ultimate sanction of a system based on specific prevention. In this view, execution would be appropriate only when the individual is found to be completely beyond redemption. As a recent decision reveals, however, the Japanese Supreme Court continues to see the death penalty in terms of general deterrence. The Tokyo District Court had found one Norio Nagayama guilty of four murders, each committed in cold blood, and sentenced him to death. ${ }^{232}$ On appeal, the Tokyo High Court noted various extenuating circumstances and concluded that the defendant had undergone a "reinarkable" transformation. ${ }^{233}$ That court reduced the sentence to life imprisonment, finding that under the circunstances "it is too harsh to apply the death sentence to defendant, and is more appropriate to have him devote the rest of his life to atoning for his offenses and praying for the repose of the victims' souls."234 The Suprenie Court reversed, explicitly referring to the relevance of general deterrence and retribution in imposing the death penalty. ${ }^{235}$ As that decision reflects, benevolent paternalisn and the emphasis on specific prevention might not apply everywhere, but they remain vital thenies for most aspects of the criminal-justice systen1. ${ }^{236}$

231. See Miyazawa, supra note 2, at 53.

232. Judgment of June 10,1979, Chisai [District Court] (Tokyo) (unreported case, on file with author).

233. Judgment of Aug. 21, 1981, Kōsai [High Court], 1019 HANנı 20, 43 (Tokyo).

234. Id. (translation by the author).

235. Judgment of July 8, 1983 (Japan v. N.), Saikōsai [Supreme Court], 37 Keishū 609, 615-16 (2d Petty Bench). In that judgment, the Supreme Court remanded the case for reconsideration of the sentence. On reconsideration, the Tokyo High Court sentenced the defendant to death, see Judgment of Mar. 18, 1987, Kösai [High Court], 1226 HaNjI 142 (Tokyo), and the Supreme Court subsequently affirmed the death sentence, see Judgment of Apr. 17, 1990, Saikōsai [Supreme Court], 1348 HANII 15 (3d Petty Bench). See also Assertion of Constitutional Violation Rejected, NiHON Keizai Shinbun, Apr. 18, 1990, at 35; Steven R. Weisman, Death Sentence Fuels Japan's Soul. Searching. N.Y. TIMES, Apr. 26, 1990, at 17.

236. It is at least arguable, moreover, that specific-prevention concerns played a substantial role in the Supreme Court's initial reversal in Japan $v N$. After referring to the general-deterrence and retributive concerns, the Supreme Court examined the arguments for leniency and made clear that it did not agree with the High Court's finding of a "remarkable" transformation, instead stating: "The defendant has persisted in his buckpassing attitude, asserting before the courts as well as in his writings that it was not he, but his parents and brothers, the society and the government who should be blamed for the offenses." Japan v. N., 37 Keishū at 615 (translation by the author). Thus, this decision can be seen as another example of the importance placed on true remorse in Japan. However, as studies have shown, for crimes regarded as the most serious, such as multiple murders and felony murders, both considerations of general deterrence, and the views of the victims and 


\section{d. The Postconviction Corrections Process}

Although maintaining order is a high priority for Japanese correctional officials, public pronouncements by such officials tend to stress the value of institutional reliabilitation. ${ }^{237}$ This public emphasis receives more than merely rlietorical support. The most important aspect of the prison experience is vocational training and work: ${ }^{238}$ over $93 \%$ of all inmates work forty-four-hour weeks. ${ }^{239}$ Japanese prisons, although spartan, do indeed resemble "factories with fences."240 Primary categories of employınent include maintenance, metalworking, tailoring, and woodworking. Labor union and other opposition to use of prison labor does not exist, and numerous private industries contract to have work performed by prisoners im or out of the prison facility. ${ }^{241}$ A number of other reliabilitative programs exist, including basic education courses, correspondence courses, and visits by volunteer groups. ${ }^{242}$

Orientation prograins are also provided for inmates both upon arri$\mathrm{val}$ and prior to release. Besides aiding in the transition to the institution, the one- to two-week "imtake orientation" provides an opportumty for evaluating the immate. ${ }^{243}$ The prerelease program consists of one week of orientation to smootl1 reentry into the outside world. As the Ministry of Justice has admitted, one week miglit on its face seem rather sliort for the prerelease orientation ${ }^{244}$ although it is still one full week more than many convicts receive prior to release in the United States. But because nost Japanese inmates leave prison in under one year, one week of orientation probably is not unduly short. ${ }^{245}$

In Japan, the granting of parole is entirely up to the discretion of the criminal-justice authorities. ${ }^{246}$ The mmate las no right to file an application for parole, nor is automatic good-behavior credit awarded. Rather,

society are accorded substantial weight iu sentencing decisions. See, e.g., Matsunaga \& Yoshida, supra note 205 , at $29,33-34$.

237. See, e.g., Correction Bureau, Ministry of Justice, Correctional Institutions IN JAPAN 21-26 (1985) (reviewing prisoner classification and grading systems, and treatment in open institutions).

238. See, e.g., William Clifford, Crime Control in Japan 90-91 (1976).

239. Correction BUREAU, Ministry of JUSTICE, supra note 237, at 28-29.

240. For a discussion of this concept, see Chief Justice Warren Burger, Factories With Fences, Commencement Address at George Washington University (May 24, 1981).

241. CoRrection BUREAU, Ministry OF JUSTICE, supra note 237, at 33; see also CiIfFord, supra note 238 , at $90-91$.

242. See Correction Bureau, Ministry of Justice, supra note 237, at 34-37.

243. Id. at 34 .

244. Id. at 35 .

245. Id.

246. See generally L. Craig Parker, JR., Parole and the Community Based TREATMENT OF OFFENDERS IN JAPAN AND THE UNITED STATES (1986). For a summary of parole and post-release programs, see Rehabilitation BUREAU, Ministry OF JUSTICE, supra note 213, at 23-30. 
the superintendent of the prison must initiate the process by requesting a regional parole board to grant parole for one or more specified individuals. ${ }^{247}$ In practice, superintendents request parole for over $60 \%$ of adult inmates, ${ }^{248}$ typically after they have served at least two thirds of their sentences. $^{249}$ The parole boards grant over $95 \%$ of such requests. ${ }^{250}$ As one would expect, the key factors influencing the grant of parole include the inmate's progress toward rehabilitation as well as the conditions in the family and community to which the inmate will return. ${ }^{251}$

The Voluntary Probation Officer (VPO) forins a link between the offender's home environment and the criminal-justice system. A VPO visits the home of the inmate at the outset of imcarceration and, if conditions exist that would inipede remtegration of the offender, seeks to improve those conditions before the inmate's release. That is one of numerous functions played by VPOs, a group of nearly 50,000 individuals who serve under a staff of approximately 800 professional probation officers responsible for the supervision and aftercare of released offenders. $^{252}$ The VPOs are generally financially stable, well-respected members of the commumity; they come from established families with close ties throughout the coinmunity. ${ }^{253}$ In contrast to the professional probation officers, who have an average caseload of nearly 150 parolees and probationers at any given time, VPOs are responsible for an average of less than two people. ${ }^{254}$ They smooth the way for the offender's return to the commumity by seeking to arrange employment and alternative housing where no family exists to receive the offender, and by visiting the offender and family regularly during the parole or probation period. ${ }^{255}$ In addition, VPOs undertake the more general function of carrying the "philosophy of rehabilitation to individual neighbors or the public as a whole [and working for the] eradication in cooperation with the coinmumity residents of environmental conditions generating crime."256

The wide network of VPOs reflects the support and involvement of

247. Rehabilitation Buread, Ministry of Justice, supra note 213, at 28.

248. Id. at 31 (tbl. 11).

249. Id. at 33 (tbl. 13). By statute, parole may be granted after one-third of the sentence has been served. KEIHŌ art. 28 (Penal Code (Law No. 45, Apr. 24, 1907)), translated in 2 EIBUNHorei-Sha LAW Bulletin SERIES PA-PC, at PA 9 (1988).

250. Rehabilitation Bureau, Ministry of Justice, supra note 213 , at 32 (tbl. 12).

251. Id. at $27-29$.

252. See id. at 10-17 (describing and gathering data on probation officers and Voluntary Probation Officers (VPOs)); Akira Tanigawa, Public Participation and the Integrated Approach in Japanese Rehabilitation Services, in UNITED NATIONS AND FAR EAST INST. FOR THE PREVENTION of CRime AND the Treatment of OfFenders (UNAFEI), CRiminal Justice in Asia: The QUEST FOR AN INTEGRATED APPROACH 328, 330-33 (1982) (assessing VPOs).

253. Tanigawa, supra note 252 , at 330-33.

254. Rehabilitation BureaU, Ministry of Justice, supra note 213 , at 11 .

255. Id. at 13-14.

256. Id. at 14 . 
the community in the criminal-justice systenı's goals of specific prevention and rehabilitation. This involventent is seen as "foster[ing] the reintegration of offenders into the free community."257 The VPOs' efforts at postconviction rehabilitation, moreover, represent only one aspect of much broader community involventent ni crime reduction. VPOs often serve in local volunteer Crime Prevention Associations, with responsibility for organizing community crime-prevention programs. ${ }^{258}$ In that role, their regular contact with prior offenders presunably aids in prompt detection of any new offenses.

III

\section{The "Benevolent PaternalisM" Model Revisited}

The outlines of Japan's benevolent-paternalism model should by now be obvious. Criminal-justice authorities keep a careful eye on the populace to detect wrongdonig. When suspicion exists, they can utilize broad tools to uncover all relevant details. In their investigation they not only pursue evidence of the crime itself, but also seek to learn about the nature and personal circuinstances of both the suspect and the victim. In achieving this aim, careful questioning of the suspect assunies central importance. Initially, therefore, the authorities may engage in rather intrusive activities, especially if the suspect refuses to cooperate.

Once armed with all the information they deein relevant, however, the authorities turn "benevolent." They probably would not characterize their actions in that inanner. Rather, they view theniselves as deterring

257. Tanigawa, supra note 252, at 330 (citation omitted); see CLIFFORD, supra note 238, at 97 109 (discussing public participation in deterrence and treatment of crime). Another element of the rehabilitative services reflecting commurity support for rehabilitation is a nationwide network of approximately 100 privately run halfway houses for releasees who lack an appropriate place to live. See Parker, supra note 246, at 116-42; Rehabilitation Bureau, MiNistry OF Justice, supra note 213 , at $17-19$.

The extent of community support can be exaggerated, however. Although many halfway houses have maintained good relations with local residents, others have been heavily criticized, and attempts to expand existing facilities or establish new halfway houses have faced considerable opposition. See Tanigawa, supra note 252, at 333-35. Of potentially greater significance for rehabilitative services is the difficulty authorities have recruiting and retaining VPOs, especially younger individuals. See id. at 331-32. Moreover, responses to a survey on attitudes toward treatment of offenders conducted by the Ministry of Justice in 1986 provide further cause for concern. Although more than $40 \%$ of respondents from the general public (and $62 \%$ of the family members of prisoners) felt that VPOs were useful in rehabilitation, over $50 \%$ of the general public either could not give a definite answer or did not know. RESEARCH AND TRAINING INSTITUTE, Ministry of Justice, GOVERNMENT OF JAPAN, SuMMARY OF THE WHITE PAPER ON CRIME 27 28 (1987). When asked how they would treat ex-offenders living in their neighborhood, 3\% of respondents from the general public indicated that they would encourage and assist in the resocialization of the offenders and another $51.5 \%$ indicated that they would treat the ex-offenders as they would treat others. Id. at 29 . But nearly $20 \%$ responded that they would have as little contact with the ex-offenders as possible, and 3\% would "hope for their removal." Id. at 29-30; see also PARKer, supra note 246, at 145-54 (summarizing criticisms).

258. See Clifford, supra note 238, at 99-102; Tanigawa, supra note 252 , at 336-37. 
crime and maintaining order. Yet the chief way in which they accomplish those ends is by seeking to remtegrate the offender into the commumity. In doing so, they place primary emphasis on reformation, which imvolves considering family circumstances, employment status, and other types of support mechanisms available to the offender, and, to a lesser extent, satisfaction of the victim. Confession also plays a key role, not just im providing the authorities with necessary infornation, but also as both a means to and reflection of the moral catharsis of the individual deemed essential to true reform. The authorities seek to utilize the means of punishment that least disrupts the suspect's life while still achieving, in their view, true specific prevention (unless the crime is so grave that resort to a higher sanction is deemed necessary for reasons of general deterrence or retribution). Where private support mechanisms are imsufficient, public support, includimg a wide network of publicly organized and officially recognized volunteers, exists to aid in the reintegration process.

This approach is consciously benevolent to the extent that it reflects the view that generosity will generate feelings of gratitude and indebtedness, thereby encouraging offenders to rehabilitate themselves. ${ }^{259}$ More importantly, though, this approach reflects the belief that the lower the level of disruption and stignia, the better the chance for effective reintegration. ${ }^{260}$ In sum, just as im Llewellyn's parental system, a key purpose of Japan's criminal-justice system is "to bring the erring brother [or sister], now known to be such, to repentance, to open confession, and to remtegration with the community."261

At the same time, Japan's criminal-justice system is fundamentally paternalistic in nature. Just as Griffiths predicted for his family model, the system depends on great trust in public officials, for it vests great discretion in them at nearly all stages of the system. Japanese police and prosecutors have wide discretion in whom to investigate and how; in determining who will be permitted to meet with suspects in detention and when; and in decidimg whom to drop from the system and at what stage. The police and prosecutors also are entrusted with preparation of the summaries of stateinents by witnesses and suspects, which, in most cases, can be adinitted into evidence. Prosecutors enjoy virtually unfettered discretion over what evidence to introduce at trial and disclose to the courts and defense counsel. When cases go to trial, prosecutors have wide latitude in their sentence requests. The courts likewise have wide

259. See Tanizawa, supra note 204 , at 203-04.

260. See Shikita, supra note 206 , at 85 (noting preference for dealing with criminal matters at a low level of formality through payment of damages, apologies, and warnings, for these reasons). Braithwaite has explored this point in considerable detail as a central tenet of his reintegrativeshaming model. See BRaITHWAITE, supra note 14, passim.

261. Llewellyn, supra note 13, at 448 . 
discretion in imposing sentences and in deciding whether to suspend them. Finally, the prison and corrections officials have very wide discretion in determining the classifications of prisoners and the timing and conditions of their parole.

Paternatism reigns supreme over every stage of the process. In the vast majority of cases defense counsel play no more than a limited role and there are few opportunities for challenge or other effective external checks on the exercise of all this discretion. Before turning to concerns such as these, however, it might be useful to address two questions: Is this picture accurate? And does Japan's system work?

\section{A. Is the Picture Accurate?}

Japanese imvestigators would likely challenge my statements regarding the intrusiveness of the system. Investigators have argued that they keep the level of intrusion to the minimum needed under the circumstances of each case. In their view, they resort to such techniques as extended "voluntary accompaniment" and arrests for other crimes ${ }^{262}$ only when they have no other means of getting at the truth, ${ }^{263}$ and they terminate preindictment detention as soon as they have completed their investigation and have confirmed that other reasons for detention, such as preventing destruction of evidence and flight, have ended. The investigators' attitude is echoed by court decisions expressly linking the scope of protections against search and seizure, interrogation, and other seemingly coinpulsory investigative measures to the needs of the imvestigators. ${ }^{264}$ But even if investigators keep their intrusions to what they regard as a bare minimum, ${ }^{265}$ I would submit that their attitude simply

262. Arrest on a separate matter (bekken taiho) is another technique that Japanese investigators solnetimes use in cases in which they suspect an individual of a relatively minor crime. Based on that suspicion, they can arrest the individual and during the period of arrest and detention question the suspect about the major crime. For a description of the use of this technique, see Ishimatsu, supra note 8 , at $64-65$.

263. A leading prosecutor, discussing the use of voluntary accompaniment, stated: “[I]t's extremely dangerous to make an arrest without a concrete confession. Yet if you send [the suspect] home, there is a strong possibility of suicide, flight, or destruction of evidence. And if we arrest the person on another charge, it will be criticized as bekken taiho." Kazuo Kawakami, Nin'i sōsa no genkai [The Limits of Voluntary Investigation], 528 HANREI TAIMUZU [HANTA] 47, 51 (1984) (translation by the author).

264. See cases cited supra notes 106 and 112.

265. This proposition is by no means clear. As described earlier, courts authorize detention in ten-day periods. See supra note 118 and accompanying text. Very few suspects are released in the first half of any detention period. See Mutsuo Nitta \& Hisaharu Yasui, Kōryū, hoshaku-saiban no tachiba kara [Detention, Bail-From the Standpoint of the Judiciary], in 1 KEII TETSUzUKI, supra note 1 , at 243,245 (tbl. 3). Less than $3 \%$ of suspects who are detained are released within the first 5 days, and only slightly more than $3 \%$ are released during days 10-15. Id. Presumably, the prosecutors themselves initiated the few instances of early release. A judge has told me privately that soine of his judicial colleagues have taken to insisting that prosecutors not detain suspects for more than five days in certain uninor cases, even though no formal means exists for enforcing such a 
confirms the picture of benevolent paternalism drawn above. This is especially revealed in the importance placed on obtaining a full confession.

Skeptics on the other side might argue that the system's "benevolence" is largely an illusion. They might observe that Japanese police and prosecutors do not seem to fit the loving, caring mold suggested by Griffiths. They could argue that, even for those suspects who have committed an offense and are released without being indicted, the experience of being investigated is by no ineans pleasant. Investigation can entail detention under strict conditions, accoinpanied by long periods of tough interrogation and perhaps even abuse. Nor would such an experience seein benevolent to one who was wrongly suspected of a crime. For those who are indicted, inoreover, detention pending trial is the norm, rather than the exception. And for those who are convicted and incarcerated, prison life will involve long hours of work, accompanied by a spartan regimen. Finally, such critics could question whether the statistics really support the conclusion that Japanese practices relating to indictment and sentencing are so inuch more lenient than those in the United States (which is by no ineans a model of lemency). They might note, for exainple, that, notwithstanding highly publicized sentences of one hundred years or inore in the Umited States, over $30 \%$ of those convicted of felonies in the United States are not incarcerated at all ${ }^{266}$ and approximately another quarter are sentenced to terms of under one year. $^{267}$

There is considerable truth to many of the skeptics' arguments, a number of which I will discuss in the context of due-process rights. ${ }^{268}$ As for incarceration, however, a closer examination of the statistics reveals a far inore lement approach in Japan than in the United States. Japan's incarceration rate of 45 per 100,000 people ranks among the low-

demand. But see Ishimatsu, supra note 8, at 66 (concluding that despite the apparent authority of judges to supervise detention, "in reality ... one simply cannot expect any supervision by the judges").

Furthermore, although following indictment bail is available as a matter of right, it is granted to fewer than $25 \%$ of suspects who are detained. See Nitta \& Yasui, supra, at 245 (tbl. 4). Prosecutors would undoubtedly argue that this simply follows from the exceptions to that right contained in article 89 of the Code of Criminal Procedure, especially paragraph 4: "[Bail shall, upon request, be granted except in the following cases:] In case there are reasonable grounds sufficient to suspect that the aceused may destroy or conceal evidence." KEIsoHô art. 89 (Code of Criminal Procedure, Law No. 131 of 1948), translated in 2 EIBUN-HoREI-SHA LAw BuLlETIN SERIES RA-RB, at RA 20 (1988) (translation emended by the author). The authorities interpret this exception to include possible fabrication of evidence and exculpatory stories. See Nitta \& Yasui, supra, at 259-65 (analyzing the current practice of denying bail). But by the time of indictment, prosecutors typically will have assembled all evidence they deem necessary, so this fear appears to be overstated.

266. Bureau of Justice Statistics Bulletin, supra note 7, at 1, 2.

267. Id.

268. See infra notes $286-331$ and accompanying text. 
est in the world; it is only about one tenth the rate of the United States, which at 426 per 100,000 is reportedly the world's highest. ${ }^{269}$ That statistic, of course, relates in part to Japan's lower overall crime rate. Yet even looking at incarceration rates for only those actually convicted at trial, nearly $60 \%$ of Japanese found guilty of Penal Code offenses do not go to prison for their crimes. ${ }^{270}$

If one takes into account other levels of benevolence, the relative leniency of the Japanese system becomes even more pronounced. Prosecution is suspended in nearly $40 \%$ of the cases referred to the prosecutors-in all of which the prosecutors have, in principle, found conclusive evidence of guilt. ${ }^{271}$ Ultimately, less than $5 \%$ of those formally identified as suspects actually go to prison in Japan, as compared to inore than $30 \%$ of those arrested in the United States. ${ }^{272}$

Levels of incarceration are not the only measure of benevolence, nor do they necessarily correlate directly with benevolence. After all, overcrowded facilities constitute one reason why substantial numbers of convicts do not go to prison in certain areas of the Uinited States. ${ }^{273}$ By the same token, the spartan conditions of prison and questioning in Japan do not in and of themselves suggest that the system lacks benevolence.

Rather, the term "benevolence," as used herein, refers to an underlying orientation toward specific prevention. The goal of a benevolent system is to achieve reformation and reintegration when possible through lenient sanctions tailored to the individual circumstances of the offender. Japanese prosecutors, judges, and corrections officials insist that their system places great weight on these goals, and the authorities' pronouncements are borne out by statistics on the use of suspended prosecutions, suspended sentences, and parole, as well as by studies of relevant factors influencing official decisions. Therein hes the peculiar benevolence of the Japanese criminal-justice system-a vastly different outlook from the general-deterrence orientation pervading criminal justice in the United States.

\section{B. Does Benevolent Paternalism Work?}

In answering this question, one inust consider what it ineans for a system to "work." For Packer's crime-control model, the answer is clear: the system works if it successfully suppresses crime. For Japanese criminal-justice authorities, I believe that the definition of success would

269. MAUER, supra note 6, at 5 .

270. See figures cited supra note 4 (figures exclude cases involving professional or gross negligence causing death or bodily injury by traffic accident).

271. But see infra note 306 and accompanying text.

272. See supra notes $2-7$ and accompanying text.

273. That is not the case in Japan, where significant prison capacity remains available. 1 HōmuSHō, supra note 222, at i (tbl. 2) (utilization rate of $85 \%$ in 1988). 
be similar: the system works if it successfully maintains order. The primary goal for each element of benevolence, however, can be defined much more narrowly. The central objective of these mechanisms lies in specific prevention-in particular, the prevention of recidivism through the rehabilitation and reintegration of offenders.

I will return to other potential definitions of success, but at the outset it seems appropriate to examine the effectiveness of the system on its own terms. Accordingly, the key initial inquiry relates to recidivisin, especially the success of the various mechamsms designed to reintegrate tlie offender into society with a miniınuin of disruption and stigma. To the best of iny knowledge, there are no statistics available that address recidivism by offenders who have been cleared froin further formal proceedings by bizai shobun. ${ }^{274}$ On a nuinber of occasions, however, the Ministry of Justice has undertaken studies of recidivisin by those in the suspension-of-prosecution and other categories. ${ }^{275}$ In the most recent and comprehensive such study, researchers tracked recidivisin within a three-year period for all individuals whose prosecutions were suspended throughout Japan during the two weeks from Septeinber 16 through Septeinber 30,1980. The study also tabulated all persons sentenced to fines, sentenced to imprisonment but with the sentence suspended, released on parole prior to completion of their sentences, and released upon coinpletion of their sentences during the calendar year $1980 .^{276}$ The results, shown im Tables 1 and 2 , are striking.

Apart froin the bizai shobun category, one can identify at least six levels of sanctions in the Japanese systein. The determination of the appropriate level of sanction depends on both the gravity of the crime and a judgment about the likelihood of the offender's successful reintegration into the community. In ascending order from the least intrusive, those categories are as follows: suspension of prosecution; fine; simple suspension of sentence (without supervision); suspension of sentence with probation (and supervision); release on parole; and release only upon coinpletion of full sentence. Withm the suspension-of-prosecution category, one iniportant additional factor is whether the suspect was referred to the prosecutors on an at-home basis or was arrested.

The recidivism statistics show almost precisely what one would have predicted for the system from its underlying theoretical bases. Those

274. Given the assumption that bizai shobun disposition is to be utilized only for minor"trivial"- - offenses, such data would not necessarily be of great relevance.

275. See, e.g., Ide \& Sato, supra note 78; Momose et al., supra note 188; Masamitsu Takeyasu \& Köichi Kikuta, Kiso yüyosha no saihan ni kansuru kenkyū [Research on the Repetition of Crime by Those Whose Prosecution Has Been Suspended], in Hōmu sōgō xenxyūsho, Hōmushō, Hō̄u

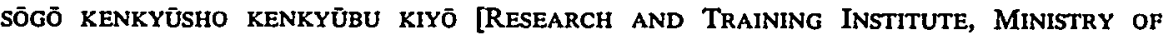
Justice, Bulletin of tHe CRiminological Research Department] 235 (1963).

276. Momose et al., supra note 188. 


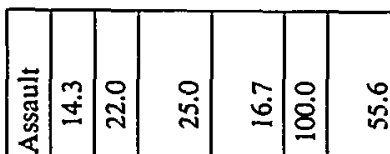

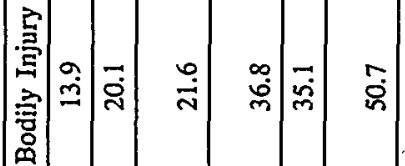

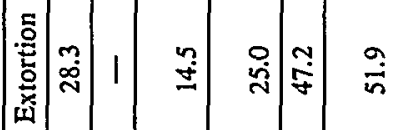

㢳

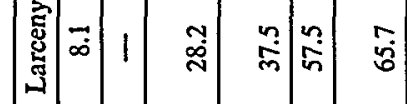

焉
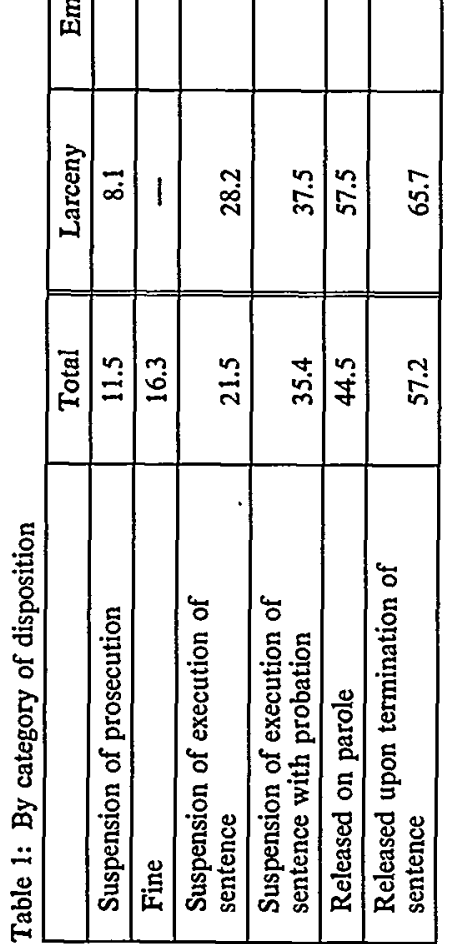

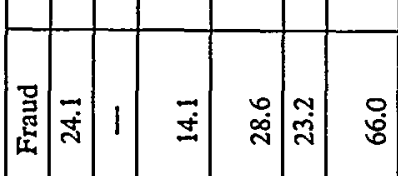

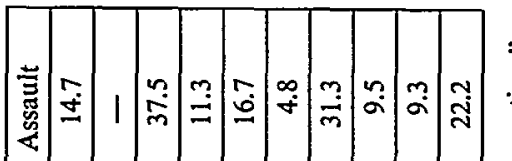

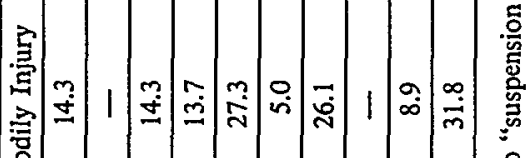

总

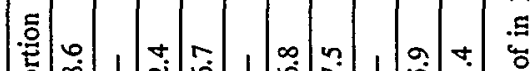

斊

幽

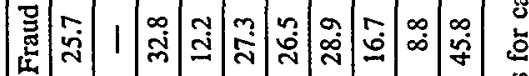

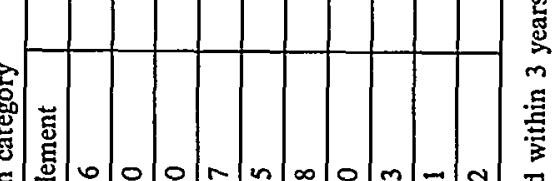

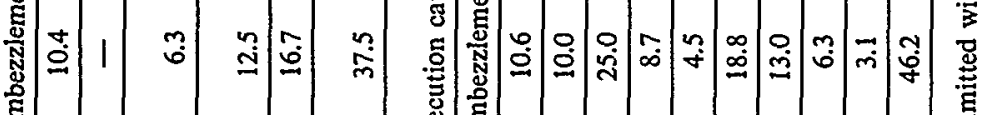



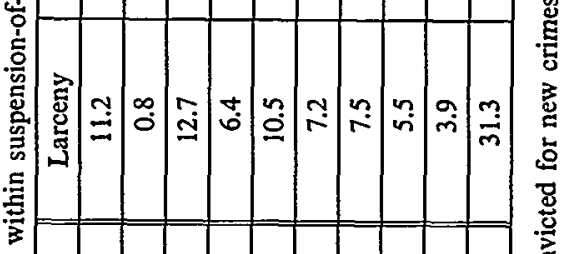

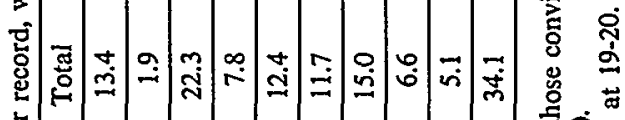

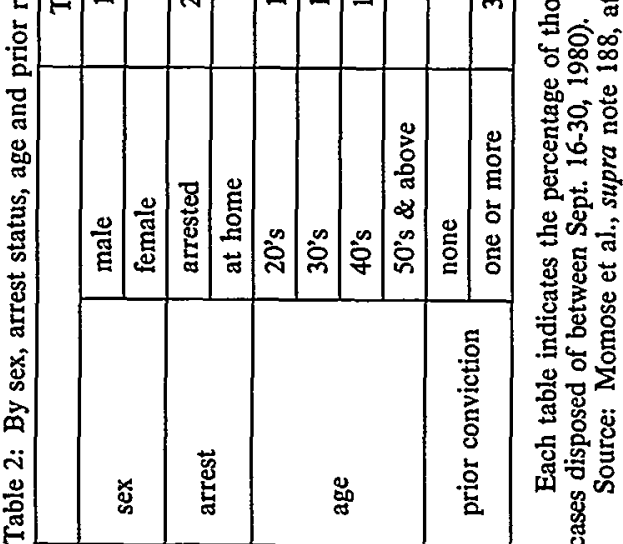


offenders deemed most likely to achieve full rehabilitation with the least intrusive level of sanctions-that is, first-time offenders whose prosecutions were suspended and offenders referred to the prosecutors on an athome basis whose prosecutions were suspended-display by far the lowest levels of recidivism (5.1\% and $7.8 \%$, respectively). Next comes the suspension-of-prosecution group as a whole (11.5\%). Recidivism rates for other categories rise progressively in tandem with the degree of severity of the sanction imposed, peaking with those offenders who are sentenced to prison and never granted parole, for whoin the recidivism rate is nearly $60 \%$.

These figures do not reflect all instances of recidivism, ${ }^{277}$ but they appear to provide a fairly reliable measure of relative rates of recidivism for the various categories of disposition. The statistics strongly suggest either that the criminal-justice authorities are very good at predicting recidivism or that the benevolence at the early stages of the system is highly effective in achieving rehabilitation and specific prevention. Unfortunately, froin this study it is impossible to tell whicl. Nor have other studies attempted to test this proposition by, for example, utilizing control groups and deliberately dealing in different ways with cohorts of apparently like-situated suspects. It seems probable that the recidivisin rates reflect a combination of botl good prediction and successful specific prevention. Yet even assuming that good prediction is the predominant factor, on the basis of these statistics one would scarcely expect Japanese criminal-justice authorities to want to change their basic approach to sanctions. Ever since the Meiji era it has been a fundamental policy of Japanese justice officials to keep lesser offenders out of prison and away from the adverse influence of hardened criminals. These statistics suggest that, for whatever reason, in the Japanese setting that approach has worked. Lemient sanctions correlate closely with low recidivisin rates. Moreover, this leniency has evidently not undermined general

277. The statistics only cover crimes (excluding professional negligence, violations of ordmances, and traffic violations) committed within a three-year period, as established by a final conviction for the subsequent offense. It is not clear from the report whether the survey covered only convictions that became final withm the three-year period or whether it used some later date to evaluate finalized convictions for all crimes committed within the three-year period. It appears that the former approach was used, which would mean that the study only considered recidivism within a period signifieantly shorter than three years.

Given the reliance on final convictions, moreover, these figures do not cover all cases of recidivism. Even where the offender is discovered, many crimes will be disposed of without indictment through bizai shobun or suspension of prosecution. See supra notes 161-66 and accompanying text. Statistics show that nearly one third of all suspended prosecutions involve offenders with prior criminal convictions, many of whom have served time in prison. See Hōmushō, supra note 120, at 342-43 (tbl. 44). It is possible that certain types of people are more likely to receive repeated suspended prosecutions. See supra notes 184-98 and accompanying text. If so, recidivism rates for the suspension-of-prosecution category may be further understated. 


\section{deterrence. $^{278}$}

Commentators and criminal-justice authorities have suggested other benefits from the system as well. They claim that Japanese justice satisfies victims, both materially through the emphasis placed on restitution and psychologically by taking their views into consideration in deciding how to treat the offenders. ${ }^{279}$ The latter, psychological benefit is rather difficult to assess, but the direct inaterial benefit for victims is readily apparent. ${ }^{280}$ In at least some cases, the involveinent and satisfaction of victims might also help enhance prospects for successful reintegration of the offender by eliminating a inajor potential source of cominumity opposition. $^{281}$ In addition, Japanese authorities assert that the lemency and general predictability of the systein engender greater trust in it among both the general public and offenders theinselves. ${ }^{282}$ In a point to which I will return shortly, however, there is at least soine question whether that perceived trust extends to all classes of society and offenders. ${ }^{283}$

\section{Tradeoffs and Drawbacks}

A broad range of interests, involving inuch more than deterrence alone, is imphicated by any criminal-justice system, and various of those interests inust be considered in assessing whether a system "works." Packer's due-process inodel inay assume, as Griffiths points out, ${ }^{284}$ that the ultimate goal of the criminal-justice system is to suppress crime. But

278. A crime-control skeptic might ask whether specific prevention undercuts general deterrence in Japan. That is, such a person might counter that the vaunted leniency of the Japanese systen in fact must induce potential offenders to take a chance and commit a crime, at least the first time.

Numerous factors influence the overall crime rate, see Setsuo Miyazawa, Learning Lessons from Japanese Experience in Policing and Crime: Challenge for Japanese Criminologists, 24 KOBE U.L. REv. 29 (1990) (discussing and summarizing various attempts to quantify potential factors), and any attempt to assess the causes of Japan's low crime rate hes beyond the scope of this Article. At the very least, however, crime rate statistics show that Japan has been able to maintain its low crime rates-and even to reduce them-during much of a postwar period characterized by increasing urbanization. See 1989 HANZAI HAKUSHo, supra note 3, at 600-01 (tbl. 1) (providing statistics for each of the 63 years of the Showa era). After falling rather steadily for most of the period from 1948 through 1973, crime rates have again gradually increased, yet they still remain well below levels of the early 1960s. Id. At the same time, authorities have been maintaining low levels of imprisonment. See id. at 617 (tbl. 9). In the Japanese setting, leniency does not appear to have undermined general deterrence in any significant way.

279. See, e.g., John O. Haley, Victim-Offender Mediation: Japanese and American Comparisons, in Restorative Justice on Trial: Pitfalls and Potentials of Victim-Offender Mediation-INTERnational Research Perspectives 105 (Heinz Messmer \& Hans-Uwe Otto eds., 1992) (NATO ASI series, Series D, Behavioral and Social Sciences vol. 64).

280. Note also that attention to restitution and the views of victims might unduly favor offenders who have the ability to pay.

281. See Haley, supra note 156, at 208.

282. Shikita, supra note 206 , at $82-83$.

283. See infra notes $317-31$ and accompanying text.

284. See Griffiths, supra note 12 , at 366 . 
one can identify in the due-process model at least four other interests that are desirable in a criminal-justice system: protection of personal autonomy (of both suspects and nonsuspects); protection against mistakes, especially mistakes that go against an innocent suspect; protection against abuse and bias; and guarantees of equality and equal treatment. The high level of discretion afforded to public officials in the Japanese system-the system's inherent paternalism-makes it perhaps inevitable to find concerns expressed regarding each of these areas. In my view, it is the degree to which they hold such concerns-in other words, the degree to which they distrnst this paternalism-that so sharply divides those who praise the system from those who decry it as "diseased" and "hopeless."285

\section{Intrusion on Personal Autonomy}

There are numerous poimts at which the Japanese criminal-justice system countenances substantial intrusions on personal autonomy. Americans with a heightened sense of privacy or distrust of authority, for example, might regard even the manned pohice boxes and regular foot or bicycle patrols of the kōban system as an unwelcome presence. ${ }^{286}$ The experience of census takers suggests that a far higher percentage of Americans would react hostilely to a system of semiannual home visits by uniformed police asking questions about the personal circumstances of each resident. And the possibility of being questioned for up to twenty-three days would undoubtedly strike most Americans as a major mtrusion on personal autonomy.

Do these observations constitute valid concerns within the Japanese setting? After all, the Japanese language, it has been observed, has no traditional word for "privacy"; a direct transliteration of the English is used instead. Notions of personal autonomy are generally much less pronounced in Japan than in the Umited States. On the whole, Japanese would indeed accept a far higher level of contact with police before they would consider it an imvasion of privacy, ${ }^{287}$ and the notion of a duty to

285. See supra notes $1,8-9$ and accompanying text.

286. I do not mean to suggest that there is any simgle point of view that can be regarded as the "U.S. view." In fact, the recent trend in the Umited States has been toward widespread acceptance of greater use of foot patrols, bicycle patrols, and other types of community-based policing. See, e.g., George L. Kelling, Order Maintenance, the Quality of Urban Life, and Police: A Line of Argument, in Police Leadership IN America 296, 299-300 (William A. Geller ed., 1985) (arguing that police emphasis on maintaining order can improve quality of urban life). It bears note that one of the factors impelling both greater consolidation into central stations and patrolling by automobile was a concern over the difficulty of monitoring abuse and corruption among decentralized footpatrol units. Id. at 296-98. Thus a key determinant of attitudes in the United States is the degree to which the public trusts police and other authorities.

287. See, e.g., Hirano, supra note 9 , at $\mathbf{4 1 6}$ (in the context of interrogation, acknowledging and criticizing a great difference in attitudes between the Japanese people, on the one hand, and 
cooperate with public officials remains strongly rooted. ${ }^{288}$

Nonetheless, recent reports of widespread resistance to residential visits by census takers in Japan suggest a rising level of concern over privacy. ${ }^{289}$ Most Japanese would regard the possibility of bemg held for up to twenty-three days without visits by family, and witl at most occasional visits by defense counsel, as a substantial intrusion. Intensive interrogation might be considered even more objectionable. ${ }^{290}$ Furthermore, the level of concern is undoubtedly inuch higher among groups that consider themselves to liave been smgled out for special "attention" by the crimmal-justice authorities. These groups include the day laborers and otller residents of the Airin district im Osaka, whicl reportedly is subject to twenty-four-liour observation by cameras mounted on street posts. ${ }^{291}$

It is wortli noting, moreover, that the Japanese appear even more sensitive than Americans to various types of governmental activities. Tluus, for example, tliere is great resistance to wiretapping, a practice

Americans and Germans); Norimichi Kumamoto, Higisha no torishirabe-bengo no tachiba kara [Questioning of Suspects-From the Standpoint of the Defense], in 1 KEUI TETSUZUKI, supra note 1, at 187, 189 (noting the Japanese people's "lack of concern" about conditions of questioning and relative lack of consciousness of the importance of human rights in the criminal process).

288. This is by no means a universal attitude. Juzo Itami's fillns $A$ Taxing Woman (Marusa no onna) and Return of a Taxing Woman (Marusa no onna II) appear to reflect accurately a deepseated resistance among inany Japanese to cooperation with tax authorities. Election-law violations represent another category of crime that many Japanese do not seen to regard as particularly wrongful, although supporters of one candidate frequently are willing to provide information about violations by an opposing candidate.

289. See Henry Cutter, Citizens Groups Grouse Over Population Census, JAPAN Trmes, Oct. 1521,1990 , at 1 (weekly int'l ed.). One possibly important distinction between these visits and the semiannual visits by police is that the census takers are private parties, hired on a temporary subcontracting basis. Japanese might be less willing to reveal personal information to such private parties than to the police.

290. Defense counsel and other critics have also alleged widespread physieal abuse and other harsh treatınent of suspects during detention. See, e.g., JOINT COMM. OF THE THREE TOKYo BAR

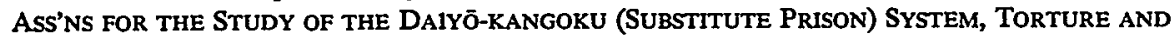

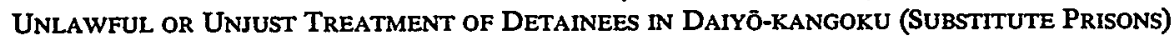
in JAPAN (1989) [hereinafter JoINT COMM.]; SōSA TO JINKEN [INVESTIGATIONS AND HUMAN RIGHTS] 63-78 (Nihon bengoshi rengōkai-hen [Japan Fed'n of Bar Ass'ns] ed., 1975); Futaba Igarashi, Forced to Confess, in DEMOCRACY IN CONTEMPORARY JAPAN 195, 196-205 (Gavan McCormack \& Yoshio Sugimoto eds., 1986). Lengthy questioning, often including psychological tactics designed to encourage confessions, oceurs regularly and is undoubtedly often accompanied by rather strict treatnient. However, accounts of observers together with the relative paucity of reported allegations suggest that outright physical abuse is rare. Perhaps this is because the investigators have many other tools with which to obtain confessions. See AMES, supra note 1, at 134-37 (discussing police cordiality with suspects and the role of a policeman as "a social worker or a clergyinan" in inducing confession); BAYLEY, supra note 1, at 152-54 (stating that ethical norms that encourage suspects to confess, as well as fiduciary relationship with suspects, mitigate against police abuse of authority); MrYAZAWA, Policing IN JAPAN, supra note 128, at 233-44 (providing examples of police interrogation techniques).

291. See supra note 100 and accoinpanying text. 
that reinains of doubtful legality in Japan. ${ }^{292}$ Notwithstanding the use of street-corner cameras, there also have been strong challenges to photographing of individuals, even in public places. In a leading case the Supreine Court upheld the right of police to take such photographs, but set out limiting standards for that right, stating: "[I]t is not permissible for the police to take photographs of an individual's face without proper reason." "293 Even Japanese prosecutors refer to sting operations, grants of immunity from prosecution, and plea bargaining as "excesses" of the U.S. criminal-justice system that would not be accepted in Japan. ${ }^{294}$ Yet another area of heightened concern relates to the public disclosure of the names of defendants. While personal names appear in the official case reports, they are normally not included in privately published case reporters, treatises, or articles. In fact, the Tokyo High Court recently awarded damages for invasion of privacy to a former defendant (who had been convicted and served a prison term for causing the death of a U.S. serviceinan) when that person's real name was used without permission in a nonfiction book about the case. ${ }^{295}$

A nuniber of factors inay help explain the sensitivity in these areas. Japanese might be inore willing to accept "natural" intrusions, against which they can take reasonable precautions, but resentful of such hidden, "artificial" intrusions as wiretapping and photography. Similarly, sting operations might be resented as another form of deceptive trickery. Arguably, each of these practices intrudes even inore roughly on personal autonoiny than do the formal door-to-door visits of uniformed pohice. Perhaps inore importantly, inembers of the iniddle class who do not normally view theinselves as arrestees or detainees might nonetheless feel vuhierable to such hidden devices or tricks. If this is so, then perhaps Hirano is right that increased imiddle-class participation in crime might lead to greater public opposition to police interrogation practices. 296

292. There is no explicit statutory basis for wiretaps in Japan and until very recently it was commonly assumed that wiretaps were illegal. Then, in two decisions stemming from the use of a wiretap in a drug case, the Kofu District Court concluded that under the circumstances the wiretap constituted a valid "inspection." See Ruling of Sept. 3, 1991, Chisai [District Court] (Kofu) (unreported case, described to the author by Professor Masahito Inouyc, University of Tokyo); Ruling of July 25, 1991, Chisai [District Court] (Kofu) (same). These decisions have come under considerable criticism, however, and to date no other court has upheld a wiretap. Conversation with Masahito Inouye, Professor, University of Tokyo, in Tokyo, Japan (Dec. 12, 1991). See generally Setsuo Miyazawa, Scandal and Hard Reform: Implications of a Wiretapping Case to the Control of Organizational Police Crimes in Japan, 23 KoBE U.L. REV. 13 (1989) (examining a case in which police tapped the phone of a Communist Party official).

293. Judgment of Dec. 24, 1969 (Hasegawa v. Japan), Saikōsai [Supreme Court], 23 Keishü $1625,1631-32$, translated in ITOH \& BEER, supra note 104, at 178-82.

294. See Yonezawa, supra note 128 , at 63.

295. Judgment of Sept. 5, 1989 (Isa v. Kōno), Kōsai [High Court], 1323 HaNJı 37 (Tokyo).

296. Hirano, supra note 9 , at 416. 


\section{Potential for Mistakes}

Within Japan, there is no question that currently the general public's single greatest concern about the criminal-justice system relates to the desire to avoid mistakes. In the investigative phase, benevolent paternalism in Japan leans rather heavily toward the crime-control model. But although this model accepts mistakes as an mevitable consequence of a system designed to suppress crime, this does not mean that criminal justice authorities in Japan (or, for that inatter, the United States) regard inistaken convictions as acceptable. In their public pronouncements and, with very rare exceptions, I am convinced, in their own minds, Japanese prosecutors and judges are not willing to accept mistaken convictions as inevitable. Yet they most decidedly do not beheve that they must accept widespread acquittals of guilty persons. Rather, they seem to be convinced that, througl thorougl investigations and questioning, they will be able to get at the "truth." 297 At the same time, the authorities (including, I suspect, most judges) regard as the most reliable factfinding that which occurs promptly, in an informal and closed setting, directed by the prosecutors-a pure example of the crime-control inodel. ${ }^{298}$ Thus, a leading prosecutor voiced a widely held attitude when he stated, "The Japanese people . . . are not at heart suited to testimony in open court." ${ }^{299}$ In addition, as noted earlier, the Japanese system does not

297. See, e.g., Joint Report, supra note 138, at 5; Shikita, supra note 206, at 83-84.

Given a conviction rate of over $99.8 \%$, though, it is probably inevitable that judges enter criminal trials with at least a subconscious assumption of guilt. See id. at 8 . One judge described the difficulty of actually issuing an acquittal:

[When acquitting a defendant,] there must not be any mistakes in one's memory of testimony or reading of depositions, and if there is any looseness in logic, the prosecutors will unquestionably attack it. To issue an acquittal ..., the opinion must be one that will withstand critical review by the higher court.

Akira Kitani, Saibankan no shokumu [The Duties of Judges], in HōGAKU SEMINĀ zōKAN, SōGō tokushū shirĩzu 27, Gendai no saiban [Hōgaku Seminar Extra Number, Special Comprehensive Series No. 27, Present-Day Trials] 243, 247-48 (1984) (translation by the author). This unguarded statement has rather sobering implications for the presumption of innocence.

298. Police do not enjoy quite the same level of trust, however. Stricter legal standards apply to the use of witness statements prepared by police than to those prepared by prosecutors. Compare KeIsoHō art. 321(1)(iii) (Code of Criminal Procedure, Law No. 131 of 1948) (requiring that witness statements to police be treated in the same inanner as statements to any third party-that is, adinissible only when the witness is unavailable, testimony is essential, and statements were made under circumstances indicating special reliability), translated in 2 EIBUN-HOREI-SHA LAW Bulletin SERIES RA-RB, at RA 69 to RA 70 (1988) with KeIsoHō art. 321(1)(ii) (Code of Criminal Procedure, Law No. 131 of 1948) (stating that witness statements to prosecutors are admissible if the witness is unavailable or if the statement conflicts with statements at trial and special circumstances make the prior statements more credible than the later testimony), translated in 2 Eibun-Horei-Sha LAw Bulletin SERIES RA-RB, at RA 70 (1988). Although there are also historical reasons for this distinction, the primary reason is the trust placed in prosecutors as highly qualified, supposedly neutral representatives of the justice system.

299. Kawakami, supra note 131 , at 888 (translation by the author). 
insist on verbatim transcripts of the closed-door questioning of witnesses and suspects, but instead accepts the widespread use of suinmaries of testimony prepared by the investigators. ${ }^{300}$ In suin, the Japanese criminal-justice systein demands the "truth"-of innocence or guilt-and places great faith in the prosecutors to discover it.

Without attempting to evaluate whether the informal closed-door investigation or formal adversarial approach is inore likely to reveal the absolute "truth," it at least should be clear that the potential for mistakes exists in either systein. In Japan, leaving aside for the inoment the possibilities of intentional abuse and unconscious bias, the situation inost conducive to mistaken determinations of guilt occurs when the police or prosecutors develop a hunch about a particular individual and then lead that individual to a confession that fits the facts as the investigators know them. Along the way the authorities reject denials or ahibis as deliberate falsification; they ehminate thein from the record as ineaningless irrelevancies.

Such mistakes imight raise concern at any stage of the systein, but they naturally becoine even more troubling as the consequences involved become greater. Thus, public trust in the Japanese criminal-justice system has been shaken in recent years by revelations that individuals were mistakenly convicted of brutal murders and wrongly sentenced to death in four separate incidents. These individuals finally achieved vindication through acquittals on retrial after spending between twenty-nine and thirty-five years each in confinement, the vast majority of that tine on death row. ${ }^{301}$ Each of these cases involved the pattern described above: investigators convinced of tlie suspect's guilt appear to have led the suspect to a confession through lengthy and intense questioning, ignoring and eliminating froun the record potentially exculpatory evidence.

Froin the time standards for obtaining retrials were relaxed over fifteen years ago, there have been only four such death-penalty acquittals. $^{302}$ Recently, the total number of retrials granted due to new evidence indicated that the original guilty verdict was probably mistaken in less tlian twenty-five cases per year. ${ }^{303}$ These surely are not the only inistaken convictions that have occurred, however. It seeins safe to assume tliat individuals given only fines or suspended sentences are not likely to go to the expense and trouble of seeking a retrial, even if truly

300. See supra text accompanying note 131 .

301. See ZoKU-SAISHIN [RETRIALS-CoNTINUED] (Nihon bengoshi rengōkai-hen [Japan Fed'n of Bar Ass'ns] ed., 1986) (analyzing and gathering materials on retrials); Miyazawa, supra note 2, at 54 (discussing retrials).

302. Other retrial petitions by capital convicts are pending. For a description of the process by which the standards were changed, see ZoKu-SAISHIN, supra note 301, at 308-21.

303. See Hidenobu Konishi, Saishin-saiban no tachiba kara [Retrials-From the Standpoint of the Judiciary], in 2 KEIJI TETSUZUKI, supra note 1, at 1011, 1012. 
innocent. It is probably impossible to determine whether the retrial cases are simply the "tip of the iceberg," as some defense counsel have contended, ${ }^{304}$ or examples of a very limited phenomenon, as prosecutors would assert. Whatever the absolute numbers of mistaken convictions, though, the retrial cases-and in particular the death-penalty retrial cases, several of which have involved allegations of egregious conduct by investigators-have affected, at least temporarily, the traditionally high levels of public confidence in the near infallibility of the criminal-justice authorities. ${ }^{305}$

Furthermore, the potential for mistakes is not limited to indictments and trials. Prosecutors offer assurances that they would only place a suspect in the suspended-prosecution category if proof beyond a reasonable doubt exists. Yet there surely must be some teinptation to place suspects in relatively close cases into that category rather than have to admit that they were released for insufficient evidence. Moreover, studies reveal that prosecutors have suspended prosecution in borderline cases where they felt they did not have sufficient evidence to ensure conviction. ${ }^{306}$ Suspects who have been wrongly indicted can at least contest the case at trial; if they win acquittal (even on appeal), they will be entitled to damages. ${ }^{307}$ If prosecution is suspended, in contrast, no mechanism exists for the suspect to contest that disposition and completely clear his or her name. ${ }^{308}$ This remains true even though that disposition can have collateral consequences, especially if the suspect is later apprehended for another crime. ${ }^{309}$

304. See, e.g., Mikio Akiyama, Higisha, bengonin no bögyo katsudō (sōsa dankai)—bengo no tachiba kara [The Defense Activities of Suspects and Defense Counsel (at the Investigation Stage)From the Standpoint of the Defense], in 1 KEII TETSUzUKI, supra note 1, at 347 (reporting that mistaken convictions are "continuing without break").

305. This is reflected in part by the outpouring of books and articles critical of various aspects of the criminal-justice system, many of which have taken their inpetus from the death-penalty retrial cases.

306. See Goodinan, supra note 130 , at $40-41$.

307. See KENPō [CONSTITUTION] art. 40, translated in CONSTITUTIONS OF THE COUNTRIES OF THE WORLD: JAPAN 18 (Albert P. Blaustein \& Gisbert H. Flanz eds. \& T.S.Y. Lee \& Osainu Nishi trans., 1990); KeIII HOSHÖHō [CRIMINAL COMPENSATION LAw] (Law No. 1 of 1950).

308. See, e.g., Tashiro, supra note 185, at 25-26 (asserting that Japanese prosecutors have a inonopoly over indictment and prosecution).

309. I am assured that in disposing of cases, prosecutors carefully examine the circuinstances of any prior grant of suspended prosecution. If a previous prosecution was suspended because of insufficient evidence, prosecutors reportedly ignore the prior charge in considering whether to indict for a later offense and, if having decided to indict, what sentence to seek. (Note that even assuning all prosecutors act in such a manner as to in effect disregard the prior suspension and thus possible prior offense of a current suspect, this itself represents yet another instance of the paternalisin and prosecutorial dominance characteristic of the Japanese criminal-justice system.)

Moreover, the suspended prosecution does in fact label a suspect as guilty, and thus has at least the potential for generating a greater stigina than an acquittal, thereby affecting social relationships of the suspect. Accordingly, it seems appropriate to require the suspect's consent to such a disposition in order to provide some means for an innocent suspect to challenge his placement in the 


\section{Potential for Bias and Concern for Equality}

The primary meaning of "equality," as Packer used tliat term, relates to wealtli and its effect on access to justice. ${ }^{310}$ In particular, the concept of equality lias implications for the level of representation that a suspect or defendant can obtain. With regard to counsel, the saine type of disparity among hitigants exists in Japan as in the United States. ${ }^{311}$ In two key respects, in fact, sucli a concern might appear to be even greater in Japan. First, although suspects must be notified of the right to retain counsel as soon as they are arrested, ${ }^{312}$ the right to appointed counsel for mdigents does not accrue until indictment, after the prosecutors have finislied questioning the suspect and largely completed their investigation. ${ }^{313}$ Second, given the limited number of attorneys in Japan, of whom only some handle criminal cases, effective access to counsel might be limited to a fortunate few. ${ }^{314}$

At another level, the dominant role of the prosecutors and the extensive discretion vested in thein increases the potential inpact of official bias-whetlier conscious or not. ${ }^{315}$ It is sometimes asserted that sys-

suspended-prosecution category. Noriharu Tashiro has made this same point, arguing that suspects who have been the objects of criminal investigations should have a "right to demand indictment" so that they can assert and prove their innocence in court. See id. at 25-29. It seems unlikely, however, that many suspeets would refuse consent to suspend prosecution, since by refusing they could end up facing a prosecution. Nevertheless, innocent suspects should be given a means of avoiding the stigma and other potentially adverse consequences of a suspended prosecution and should not have to rely on subsequent prosecutors to evaluate correetly a prior suspended prosecution.

310. See PACKER, supra note 10, at 168-70.

311. See GENDAI SHIHō KENKYūSHA GURŪPU, DOKYUMENTO ROKKĪDO SAIBAN [MODERNDAy Justice Researcher Group, Document: Lockheed Tr1al] 13 (1979) (commenting on the unusually high quality of counsel-including a former Supreme Court Justice, a former High Court Chief Judge, and a former Procurator General-defending former Prime Minister Kakuei Tanaka in a bribery case).

312. KENPō [CONSTITUTION] art. 34, translated in CONSTITUTIONS OF THE COUNTR1ES OF THE WORLD: JAPAN 17 (Albert P. Blaustein \& Gisbert H. Flanz eds. \& T.S.Y. Lee \& Osamu Nishi trans., 1990); Keisohō art. 203(1) (Code of Criminal Procedure, Law No. 131 of 1948), translated in 2 Eibun-Horei-Sha LAW Bulletin SERIEs RA-RB, at RA 44 (1988).

313. See KEISOHŌ art. 272 (Code of Criminal Procedure, Law No. 131 of 1948), translated in 2 Eibun-Horei-Sha LAw Bulletin Series RA-RB, at RA 60 (1988) ("The court shall, in case the public prosecution has been instituted, notify the accused without delay to the effect that he may appoint counsel and that he may request the appointment of counsel when he cannot do so because of poverty or other causes ....") (translation emended by the author and emphasis added).

314. See Akiyama, supra note 304, at 350-51.

315. In the United States, numerous procedural and substantive restrictions are placed upon the discretion of criminal-justice authorities out of concern over the possible abusive and arbitrary exercise of such discretion. The relatively recent trend toward "determinate" sentencing, which requires judges to impose sentences within a narrow, statutorily specified range unless they specifically find aggravating or extenuating circumstances, reflects this concern. See Andrew von Hirsch, Recent Trends in American Criminal Sentencing Theory, 42 MD. L. REV. 6, 31-32 (1983). This, of course, is nothing new in the United States; fear of unfettered discretion and distrust of authority are common themes rooted deeply in, among other things, the great diversity of American society and concerns over oppression. 
temic oppression does not exist in Japan and that the homogeneous nature of Japanese society reduces the danger of bias. Most recent criticism of Japan's criminal-justice system has focused on the potential for mistakes rather than concerns over deliberate abuse or unintentional bias. ${ }^{316}$ Yet one need only recall the "thouglit control" directed at leftists in the prewar years for clear evidence that oppression of political dissidents is by no means unknown in Japan. ${ }^{317}$ More recently, allegations of politically inotivated prosecutions and harsh treatment of suspected leftists contimue to arise. ${ }^{318}$ These allegations find support in accounts of the special "attention" focused on leftists by the police ${ }^{319}$ and prosecutors, ${ }^{320}$ as well as a recent finding that police illegally wiretapped the telephone of a Japan Communist Party official (a crime that prosecutors declined to prosecute). ${ }^{321}$

As numerous observers have noted, claims of Japanese homogeneity are overstated. ${ }^{322}$ Apart from leftists and otlers with differing ideological viewpoints, substantial minority groups include Koreans and the burakumin (descendants of outcast groups). In light of traditional attitudes, it is not surprising to find reports that police keep these minority groups under close watch. ${ }^{323}$ Although no comprehensive study of the issue has been undertaken, critics allege that Koreans, burakumin, and fringe groups such as the indigent and day laborers are subject to police prejudice and harsh treatment. ${ }^{324}$ Reports indicate that Korean residents of Japan frequently do not cooperate witl authorities and refuse to provide the all-important confession. ${ }^{325}$ The authorities, accordingly, might treat inembers of this minority group as if they liave failed to satisfy one of the key conditions for leniency. Furthermore, given the emphasis that prosecutors place on such factors as employinent, friends,

316. See, e.g., Akiyama, supra note 304; Ishimatsu, supra note 8.

317. See Mrrchell, supra note 74.

318. For an account of the most celebrated such postwar case, see Chalmers JoHnson, Conspiracy at Matsukawa (1972).

319. See, e.g., AMES, supra note 1, at 142-48.

320. See, e.g., Goodman, supra note 130, at $43-44$ (noting continued attempts by prosecutors to bring about a "change of heart" (tenko) in radicals by convincing them during the interrogation process of the inappropriateness of their ideological views).

321. See Miyazawa, supra note 292, at 18-21.

322. See George DeVos \& Hiroshi Wagatsuma, JaPan's InVisible Race (1967) (containing studies devoted to analyzing caste behavior in Japan); RICHARD H. MITCHELL, ThE Korean Minority in Japan (1967); Frank UphaM, Law and Social Change in PostwaR JAPAN 78-123 (1987) (discussing the political activity of burakumin).

323. Police reportedly fear that the Korean population is involved with Communism, see AMES, supra note 1, at 95-99, and claim higher crime rates for burakumin, see id. at 99-104.

324. See, e.g., Shingo TaKasugi, Buraku Sabetsu to enzai [Buraku Discrimination AND MISCARRIAGES OF JUSTICE] 216-24, 240-42 (1977) (furnishing examples of discriminatory treatment); KōsuKe YaGl, SABETSU TO ENZAI No KöZó [DisCrimination aNd THE STRUCTURE OF MisCARRIAGES OF JUSTICE] (1976).

325. See AMES, supra note 1 , at 97-99. 
and other types of support mechanisms to help ensure effective reintegration into the cominumity, even the seemingly neutral application of the usual standards might result in stricter treatinent of day laborers, the poor, and soine burakumin.

A much more ambiguous relationship appears to exist between the police and another group of "outsiders," the yakuza (members of organized crime gangs). Considerable cooperation-and even feelings of ideological solidarity-between the police and yakuza have been reported. ${ }^{326}$ Prosecutors recently highlighted one alleged instance of such preferential treatment by indicting a policeinan for accepting a bribe froin yakuza. ${ }^{327}$ Day laborers and other residents of a lower-class neighborhood in Osaka reportedly interpreted the indictment as an official confirmation of their long-held complaints of discriminatory treatinent by the police, and those residents responded with fierce rioting (documented by the police cameras that, as mentioned earher, survey the neighborhood). ${ }^{\mathbf{3 2 8}}$

In addition, in recent years new minority groups have begun developing in Japan, primarily through the arrival of growing numbers of foreign workers. That influx has been accoinpanied by widespread reports of the criminal prochivities of many such new arrivals. As a result, criminal-justice authorities have stepped up their surveillance and prosecution of members of these groups. ${ }^{329}$ The authorities who deal with these new arrivals have also reported practical difficulties such as the need for interpreters and the lack of prison space suited to foreigners. ${ }^{330}$

In a criminal-justice system based on reintegration into the coinmunity, the presence of groups that have not been-or consciously choose not to be-assimilated presents a fundamental dilennma for authorities. In this connection, I am reminded of a visit I made to a prison that housed both Japanese and foreign convicts (especially American servicemen). The Japanese inmates were working diligently, presumably as a step in their rehabilitation process; the foreiguers were playing basketball. I remember thinking that it is pointless to give vocational training to inmates who will leave Japan as soon as they are given the chance. However, many of the new wave of arrivals would, if given the option, choose to remain in Japan, where even the lowest wages are likely to be much higher than those available in their own home countries. In the case of such immigrants the justice system will likely opt for deportation, either before or after imprisonment. But that might not be possible in all cases. Nor is it a possibility for Japanese citizens, froin the radicals at

326. See id. at 105-29.

327. See Weisman, supra note 100.

328. Id.

329. See Japan's Illegal Tide, NewsweEk, Sept. 11, 1989, at 10, 14 (Asian ed.).

330. Id. 
one end of the spectrum to the yakuza and ultranationalists at the other, who refuse to conform. Ultimately, the benevolent-paternahism system rests on reintegration into society on society's own terms. The system demands acceptance of those terms by those wishing to receive leniency. ${ }^{331}$ For the groups that do not or will not fit, a shift in focus to crime control and an einphasis on punishment might be inevitable in the Japanese setting.

Even in a society that appears completely homogeneous, soine degree of bias-on regional, class, or other grounds-seems inevitable. As the preceding discussion shows, Japan is not truly homogenous and there is ainple reason for concern about potential bias and discrimination. In view of the great discretion afforded to criminal-justice authorities at nearly every stage in Japan's criminal-justice systern, there are numerous points at which such bias-conscious or not-could, and at least in soine cases clearly does, affect outcomes.

\section{Possible Remedies}

In recent years, Japanese practitioners (including judges and prosecutors) and scholars have proposed a wide variety of reforms for the criminal-justice system. The proposals do not all involve the saine concerns. Some relate to the level of intrusion on personal autonomy and others to issues of equality and the potential for bias. The vast majority, however, focus on avoiding mistakes; the outpouring of proposals is a clear reflection of concern over the mistaken death sentences. The proposals soinetimes seem to lack internal consistency. Many defense counsel, for example, criticize the prosecutors for being too thorough and too intrusive, but in the next breath chastise them for not achieving absolute perfection in their factfinding. In response to the latter criticisin, some prosecutors conclude that they must exercise even greater care in their questioning to ensure that they do not miss any potentially relevant detail. ${ }^{332}$ Whether or not this would etiminate mistakes, ${ }^{333}$ it surely would not reduce the level of preindictment intrusion on the suspect's personal autonomy. An even inore fundamental question, though, is whether the proposed reforms are coinpatible with the amimating prem-

331. As Braithwaite observed, this point can be stretched too far. For example, absolute conformity is not essential to reintegration, nor do most subcultures reject all of the basic principles of the criminal law. See BRAITHWAITE, supra note 14, at 38-43. In Japan, though, certain elements of reintegration, such as full confession, are so ingrained that refusal to comply would likely be deemed evidence that the suspect is not yet ready for a return to society.

332. See Toshiyuki Hyötani, Saikin no saikōsai hanketsu ni tsuite-jithaku no shin'yōsei o chüshin ni [Regarding the Recent Supreme Court Judgments-Focusing on the Reliability of Confessions] (pt. 2), 33 SōSA KENKYū, Oct. 1984, at 1, 4; Yonezawa, supra note 128, at 64.

333. Defense attorneys contend not that the questioning of suspects is insufficiently thorough, but rather that prosecutors subconsciously filter out statements that do not fit their intuition. 
ises of the existing system-in particular, the emphasis on utilizing the minimum level of sanctions deemed necessary in light of all of the individualized circumstances of each suspect. ${ }^{334}$ This, in turn, raises the question of whether the concerns identified in the preceding section are inevitable consequences of any benevolent-paternalism or family-type system.

\section{Limits on Questioning}

One type of proposal that has garnered considerable support relates to limiting the scope of permissible questioning. Proposals of this type mclude eliminating questioning, ${ }^{335}$ permitting defense counsel to attend questioning, ${ }^{336}$ introducing stricter time limits, ${ }^{337}$ and eliminating the "duty to submit to questioming"- that is, recognizing a right for suspects to leave the imterrogation room..$^{338}$ The most widely discussed proposal of this type currently, though, relates to the place of detention. Critics have argued strenuously agamst the practice of holding suspects in police cells where they are readily accessible for questioning by investigators, and instead have advocated that suspects should be held in prisons, beyond the easy reach of imvestigators. ${ }^{339}$

The primary impetus for these proposals is to reduce the level of intrnsion on the personal autonomy of suspects. But a further rationale

334. I might note at the outset one type of proposal that has not received much attention: instituting mandatory prosecution of all suspects decmed convictable and shifting to determinate sentencing as a means of reducing the discretion of criminal-justice authorities. Very few people, it seems, want to take the step of eliminating the discretion and leniency upon which the system is based. Hirano did suggest requiring proseeutors to prosecute in all convictable cases, both as a means to reduce the pressure on prosecutors to achievc almost complete certainty in their investigations and as a means of shifting the focus of the process from the prosecutors to the courts. See Hirano, supra note 9, at 408-09. Although the defense bar was quick to adopt his characterizations of the system as "diseased," it was notably less enthusiastic about adopting thc idea that more suspects should be indicted. See, e.g., Tokushü, Ima Nihon no keiji saiban wa [Special Issue: The Present Status of Criminal Trials in Japan], JiYū TO SEIGI 38-2-3 (1987) (notc introducing a special issue of the monthly journal of the Japan Federation of Bar Associations, devoted to the topic of criminal justice, leading off with a quotation from Professor Hirano describing the current system as "hopeless," but at no point thereafter discussing his suggestions that one possible reform might be to imcrease the level of indictments).

335. Takayuki Shiibashi, Higisha torishirabe [Questioning of suspects], 61-10 HöRITSU jı̈ō 16, 16 (1989) (mentioning but rejecting a proposal to eliminate questioning).

336. Kumamoto, supra note 287 , at 194.

337. Shiibashi, supra note 335 , at 18 .

338. Id. This proposal has a long history, dating back to 1958. See Hirano, supra note 11, at 106.

339. See, e.g., JoINT CoMm., supra note 290; Igarashi, supra note 290. For three points of view on this debate, sec Yoshikazu Ishii, Taiho, kōryū no basho (fu, daiyō kangoku)-bengo no tachiba kara [The Place of Arrest and Detention (Including Substitute Prisons)-From the Standpoint of the Defense], in 1 KEIJ TETSUzUK1, supra note 1, at 281; Reiichi Miyazaki, Taiho, kōryū no basho (fu, daiyō kangoku)-kensatsu no tachiba kara [The Place of Arrest and Detention (Including Substitutc Prisons)_From the Standpoint of the Prosecution], in 1 KEIJI TETSUzUKI, supra note 1, at 273; Yoshifusa Nakayama, Komento [Comment], in 1 KEIJI TETSUzUKI, supra note 1, at 289. 
is to avoid mistakes, based on the danger that confessions obtained after lengthy questioming under current conditions might be unreliable. Questioning normally leads to extensive information. Much of that information is undoubtedly true, but soine might be false. Whatever the inpact on personal autonomy and other interests might be, the total elimination of questioning would exclude a major source of both types of information and in itself would not seem likely to advance the search for truth. ${ }^{340} \mathrm{On}$ the other hand, more specifically tailored limits on the length and conditions of questioning might reduce the circumstances most likely to result in false confessions without blocking access to information altogether. Moreover, such himits might force investigators to hunt more carefully for evidence other than confessions. Thus such a reform might help to avoid soine of the inistakes produced by the current system.

Yet questioning and confessions play a far greater role in Japan than factfinding alone. As discussed earhier, the process of thorough questioning leading to a full and sincere confession is regarded as a crucial means of achieving the repentance and moral catharsis considered an essential part of rehabilitation and reintegration. ${ }^{341}$ This central role of confessions and repentance, it should be noted, also characterizes the parental model described by Llewellyn based on his observations of the Cheyenne and New Mexican Pueblos. ${ }^{342}$ A system committed to achieving rehabilitation must ensure that offenders accept certain basic tenets of the existing social order and understand that their conduct was wrongful under those tenets. These goals may require thorough questioning and insistence on careful self-reflection. They do not require, however, that Japanese criminal-justice authorities be given free rein to investigate without regard for the duration and conditions of questioning. Yet it is clear that proposed limits on the duty to submit to questioning collide with a fundamental premise of Japan's benevolent paternalism.

Another possible option is to forbid intensive questioning until after conviction, although I have not seen any references to it in the Japanese literature. From a due-process perspective such an approach would afford inportant protections, by providing a tool for inducing confession and repentance while ensuring that the use of the tool would be limited to those who have already been found guilty.

Japanese prosecutors would probably respond that, under the current regime, no posttrial inechamism exists for the sort of intensive questioning needed to achieve the desired repentance. But this response begs

340. Such a step presumably would force investigators to undertake more thorough investigations of physical evidence, which could improve some aspects of the "search for truth." However, eliminating most confessions out of concern over the reliability of a small number does not seem likely to improve overall accuracy of factfinding.

341. See supra note 130 and accompanying text.

342. See supra text accompanying notes 65-66. 
the question, since corrections officials or the courts could undertake such a role. A more fundamental objection is that a high level of questioning at the end of the criminal-justice process might encourage suspects to remain silent until that stage and that this might undercut specific prevention. Prosecutors would undoubtedly contend that postponing questioning would force them to imdict suspects whose prosecutions would otherwise be suspended or even dropped altogether, thus heightening the stigma for such suspects and rendering their reintegration into society more difficult. ${ }^{343}$ Delaying the questioning, they might further assert, would hamper efforts at rehabilitation by forcing the suspect into a dernal mode until after the conclusion of the trial. ${ }^{344}$ Once again, efforts to minimize imtensive questionmg appear to confront the system's primary emphasis on rehabilitation and reintegration.

\section{Strengthening the Adversary System}

Other reform proposals address the functioning of the adversary system. As mentioned earher, the Occupation envisioned a heightened role for the adversary process in Japan, and in form the crimmal-justice system is distimctly adversarial. In practice, however, the role of defense counsel tends to be quite circunscribed. This limited role stems partly from the small number of attorneys practicing criminal law in Japan and from traditional attitudes toward their role. Additionally, the system himits the sphere of influence of defense attorneys, both in their activities and in the substantive arguments they can raise. For example, defense counsel are permitted only limited meetings with suspects prior to indictment and are unable to attend questioning sessions or pursue effective discovery. The broad powers of investigators and broad exceptions to the hearsay rule, coupled with a very narrow exclusionary rule, combine to limit viable challenges to the admissibility of evidence. ${ }^{345}$ Under the circumstances, an eloquent plea for clemency might be the best tool available to the defense attorney.

"Best tool for what?" one might ask. The precedimg paragraph assumes that the primary duty of defense counsel in Japan is to obtain the most lemient treatment possible-including acquittal-for a client, regardless of the chent's guilt or imdividual needs. In the family model,

343. Cf. Tashiro, supra note 185, at 37-38 (arguing against shift from suspended prosecutions to suspended sentences for this reason).

344. An intermediate step would be to delay the intensive questioning until the trial. This appears to be the practice in the parental systems Llewellyn describes, and from a due-process perspective would permit judges and defense counsel to monitor and participate in the questioning. Japanese prosecutors would undoubtedly regard this as wholly unacceptable, too. They would voice all the concerns referred to in the text, and would also argue that close one-on-one questioning is essential to achieving true acceptance of responsibility and remorse.

345. See supra text accompanying notes 133-44. 
Griffiths suggested, the role of defense counsel would be different. ${ }^{346}$ The relationship between defense counsel and the prosecutors would be "cooperative, constructive, conciliatory." ${ }^{347}$ Defense counsel presumably would act as a check, to ensure that innocent individuals were not wrongly implicated. At the same tinne, defense counsel would cooperate with the state to make sure that all relevant facts concerning the suspect, including the suspect's factual guilt, were brought to light, thereby enabling the state to determine the sanction that would best serve the interests of the suspect and society as a whole.

The attitude described by Griffiths exists among many defense counsel im Japan. Their greatest concern is that innocent individuals not be mistakeuly convicted. For the most part, sucli concern is not accompanied by the view that the system itself is so biased ${ }^{348}$ or so uncommitted to rehabilitation ${ }^{349}$ that defense counsel slould try to win an acquittal any way possible. Even in contested cases, most Japanese defense counsel routmely consent to the adnnission of almost all the witness statements prepared by the prosecutors rather than exercise their right to demand that the prosecutors produce available witnesses for testinnony in court. ${ }^{350}$ Moreover, defense counsel frequently encourage suspects to confess (at least if the suspects are guilty), and advise them regarding the proper amount and manner of restitution. ${ }^{351}$ Defense counsel undoubtedly do so primarily because they recognize the importance placed on these elements if the suspect wisles to receive lenient treatnient, but they may also be indirectly aiding in the reintegration process. At times, defense counsel assist even nore directly in reintegration by interceding with a suspect's family or employer to ensure continued support and employment for the suspect. ${ }^{352}$

This is by no ineans the exclusive attitude of defense counsel, lowever. The defense bar routinely emphasizes both the role of defense counsel and the adversary process in ensuring due process and protectimg

346. See Griffiths, supra note 12, at $383,404-10$.

347. Id. at 383.

348. See, eg., Francis A. Allen, The Decline of the Rehabilitative Ideal 9 (1981) (noting criticism that rehabilitation efforts function "as machimery devised and operated to oppress the poor and powerless and to advance the economic and political interests of the dominant social classes").

349. See Griffiths, supra note 12, at 408-09 (justifying defense counsel's pursuit of acquittal on grounds that "the consequences of a conviction are so pointless, so calculated to do nothing but harm to the convicted man and so little apparent good for anyone else, that the most sociallyconscious [sic] and ethical lawyer can wholeheartedly believe it his duty to secure an acquittal in any permissible way").

350. See Hiratani, supra note 131 , at $\mathbf{8 8 2 - 8 5}$ (examining situations in which witness statements serve as evidence).

351. See, eg., Goodman, supra note 130, at 35; Haley, supra note 212, at 272.

352. Conversations with Judge Takeo Setoguchi and Haruki Sugiyama, Tokyo District Public Prosecutor's Office, in Seattle, Wash. (Nov. 1990). 
the human rights of suspects and defendants. ${ }^{353}$ Among police and prosecutors, in contrast, the perception is rather widespread that defense counsel in some cases overstep the bounds of propriety in seeking to obstruct prosecutions. ${ }^{354}$ Against this backdrop, proposals for enhancing the role of defense counsel have met with only modest success. Prosecutors recently have loosened somewhat the limitations on preindictment meetings between suspects and counsel. ${ }^{355}$ But they continue to place very strict limits on meetings with counsel in cases involving bribery and election-law violations, in which the charges are among the most difficult to prove unless one of the participants confesses and in which the danger of fabrication of excuses is regarded as highest. Attendance at interrogation sessions by defense counsel remains out of the question. In true paternalistic fashion, the view that prosecutors can and should be trusted to investigate all relevant inculpatory and exculpatory evidence remains dominant. Activities by defense counsel that might interfere with the prosecutors' investigation are unlikely to fare well under a benevolentpaternalism model.

\section{Discovery and Disclosure}

Similarly negative attitudes toward defense counsel help explain why defendants have not secured broader rights to discovery. Currently, defense counsel can obtain discovery (even of exculpatory evidence) only with a court order, and even the Supreme Court's most progressive precedent in this area makes clear that a court would be justified in issuing suclı an order only under very narrow circumstances. ${ }^{356}$ Numerous critics have proposed expanding rights to discovery as a partial reinedy for bias and mistakes in the criminal-justice system. ${ }^{357}$ The right of defense counsel to discover information in the prosecutors' files would seein to

353. See, e.g., OSAKa bengoshi Kyōdō kUmiaI hakKō, SōSA bengo No Jitsumu [OSAKa Attorneys Mutual Aid Ass'N, The Actual Practice of Defending Against INVESTIGATIONS] 2 (1991) [hereinafter OSAKA ATTORNEYS].

354. See, e.g., Kazuo Kawakami, Komento 2 [COMMENT 2], in 1 KeIjI TETSUzUKI, supra note 1 , at 367, 367-68. The feared activities include hiding or destroying evidence and, in particular, aiding witnesses and other potential suspects in developing a plausible alibi.

355. The partial relaxation in standards was accomplished through a so-called circular (tsütatsu), an internal document with no binding effect, which has not been released to the public. A practice manual recently prepared by the Osaka defense bar, however, contains a summary of the new standards. See OSAKA ATTORNEYs, supra note 353, at 91-92.

356. Ruling of Apr. 25, 1969 (Japan v. Kozura), Saikōsai [Supreme Court], 23 Keishū 248 (2d Petty Bench). Kozura established that, among other conditions, defense counsel must indicate specific evidence for which concrete need can be shown. Id. at 250 . If such need exists, the court in its discretion may order disclosure if it finds examination of the evidence especially important to the defense and finds that there is no danger of harm-such as destruction of evidence or threatening of witnesses-from discovery. Id.

357. See, e.g., Yasukuni Yoneda, Shöko kaiji-bengo no tachiba kara [Disclosure of EvidenceFrom the Standpoint of the Defense], in 2 KEIJI TETSUzUKI, supra note 1, at 515. 
provide a meaningful check not only on mistakes but also indirectly on bias and even unwarranted intrusions on the personal autonomy of suspects. Prosecutors continue to resist strenuously any such discovery, however. Apart from raising theoretical concern about the absence of mutuality for such discovery (that is, the mability of prosecutors to compel discovery from the defendant), ${ }^{358}$ they point to the possibility that defense counsel would abuse the mformation they discover. They assert that isolated pieces of seemingly exculpatory evidence might be overemphasized by defense counsel, thereby distorting the determination of guilt. In the words of one prosecutor:

If one percent worth of evidence suggesting that the defendant might perhaps be innocent is introduced after ninety-nine percent worth of evidence of guilt, it is not inconceivable that at times a judge inay be misled [by the later evidence], especially if it turns out that it was in the possession of the prosecutors. ... It is clear that this is not the proper result from the standpoint of the principle of actual truth. ${ }^{359}$

Ultmiately, therefore, the official attitude toward discovery consists of the basic paternalistic view that the prosecutors will accord all evidence the weight to which it is entitled. This is coupled with the fear that defense counsel will not take the "cooperative, constructive, conciliatory" stance of Griffiths' ideal representatives, but rather will prove to be the aggressive adversaries of the battle model. While the courts might not be entirely comfortable granting the prosecutors such sweeping discretion, they appear to be even more reluctant to place defense counsel in a position to oversee the criminal-justice system-presumably out of fear that additional discovery might disturb the existing balance between prosecutors and defense counsel. ${ }^{360}$ At present, such concern seems unwarranted. Neither the confrontational tactics adopted by defense counsel in some cases nor numerous publications (some even authored by prosecutors) urging defense counsel to undertake more aggressive representation $^{361}$ have altered the usual stance of defense counsel, which appears to remaim "cooperative, constructive, [and] conciliatory." Nevertheless, fears that reform will some day lead to a "hired gun," "win at

358. See Kawakami, supra note 354 , at 531, 533. Given the investigators' wide powers to question suspects, this objection would seem to have even less persuasive power in Japan than in the United States. See generally 2 WAYNE LAFAve \& Jerold H. IsRaEL, Criminal Procedure $\$ 19.3$ (a) (1984) (pretrial discovery for the defense-policy considerations).

359. Kawakami, supra note 354, at 533 (translation by the author).

360. I should also note that the Code of Crimmal Procedure does not refer to discovery at all. The inherent authority of the courts over criminal proceedings presumably could be interpreted to encompass the right to order discovery (this, in fact, was the narrow issue in Kozura, discussed supra note 356 and accompanying text). But in the absence of express statutory authorization, the courts might naturally be hesitant to order discovery as a routine matter.

361. See, e.g., OsAKa ATroRneys, supra note 353, at 2 (manual prepared by Osaka defense bar, intended to help "invigorate" representation); Kawakami, supra note 1, at 16-17 (prosecutor urging more "zealous" representation by defense counsel). 
all costs" mentality represent a powerful practical barrier to heightened rights of discovery by defense counsel.

One possible approach that would avoid reliance on defense counsel would be to order routime disclosure of the full prosecutorial file to the court itself. This would seem to ehmmate concerns over possible abuse by defense counsel while enabhing the court to provide more of a check against mistakes. If given the entire file, the court might also choose to inquire into such matters as bias and undue intrusion on the suspect's autonomy. Not entirely coincidentally, this proposal would revive a feature of pre-Occupation procedure that was deliberately dropped at the same time that the adversary process was strengthened. The Occupation aimed to ensure that the prosecutor's dossier would not unduly influence the court; rather, the Allies envisioned that the newly invigorated adversary system would provide a strong check on prosecutorial activities. ${ }^{362}$ A return to such a system of controlled disclosure might be seen as simply adding one more layer of paternalism and presumably would be criticized by defense counsel, ainong others, for not going far enough. Under the current regime, however, many criminal judges see theinselves as merely confirming the prosecutor's determinations on the basis of a selective file. ${ }^{363}$ Submitting the prosecutor's file to the court inight provide a partial check on one level of the systein without raising the specter of a pervasive battle-model mentality.

In suin, it appears that the only types of changes that crininal-justice authorities and courts in Japan might consider adopting are relatively increinental measures that would not significantly limit the range of investigative authority or the discretion of officials and that would not proinote a more strongly adversarial position by defense counsel. In view of the basic structure and overall success of the benevolent-paternalism model, the reluctance to undertake inore fundainental changes seeins inevitable, notwithstanding the heavy orientation of the Constitution and numerous provisions of the Code of Criminal Procedure toward due-process rights and the adversary systein.

\section{CoNCLUSION}

In evaluating Griffiths' family model, soine commentators have concluded that such a model could exist only in a primitive, stateless, or totalitarian society. ${ }^{364}$ The operation of benevolent paternalism in Japan suggests otherwise. Is Japan unique in this regard? I suspect not. Accounts concerning the Netherlands, for exaniple, describe a criminaljustice system that bears a striking reseniblance to that of Japan in

362. See Appleton, supra note 89, at 413-14.

363. See, e.g., Joint Report, supra note 138, at 5-8; Ishimatsu, supra note 8, at 62.

364. See supra notes 20-22 and accompanying text. 
numerous respects. These features include the extent and types of discretion afforded to criminal-justice officials; the conscious use of leniency (includimg extensive pretrial diversion); the deliberate deemphasis of imprisonment; the emphasis placed on confessions; and the importance of informal community and social controls. ${ }^{365}$ Further research would probably disclose the same underlying einphasis on specific prevention as a central focus at all stages of the Dutch criminal process.

A major difference between the two nations, however, is that crime rates have risen dramatically in the Netherlands smce $1975,{ }^{366}$ while they have remained generally stable in Japan. Possible reasons for the rising crime rate in the Netherlands include a breakdown in informal social controls and rising drug probleins. ${ }^{367}$ One other trend could be highly significant: a decline in the Netherlands' clearance rate. ${ }^{368}$ That decline is in part a syinptom of the rising crime rate, of course, but might it also be a cause? Minoru Shikita, a leadimg Japanese criminal-justice official, has contended that the suceessful functioning of Japan's systein depends heavily on the high clearance rate-that leniency becoines possible precisely because of the relative certainty of detection. ${ }^{369}$ If, in other words, the great majority of offenses are promptly detected and appropriate steps are taken to reform and reintegrate the offenders, there inight be little need to impose harsh sentences on an unfortunate few as a means of deterring other potential criminals. Thus, in Shikita's view, the systen fights crime on two levels: specific prevention rehabilitates most of the offenders who are apprehended and general deterrence-the certainty of apprehension-intimidates the population as a whole. ${ }^{370}$

Assuming that this theory is true, might Japan be on the same course as the Netherlands, just a decade or two behind? Japan's low crime rate undoubtedly arises from a wide coinplex of factors, and I would not suggest that benevolent paternalisin in the adninistration of justice is the sole or even the primary determinant. ${ }^{371}$ Yet might a rise in

365. See David Downes, Contrasts in Tolerance (1988); Arthur Rosett, Trial and Discretion in Dutch Criminal Justice, 19 UCLA L. REV. 353 (1972). Sweden has been suggested as another example of a "parental" system. See Herrmann, supra note 20, at 16.

366. See Downes, supra note 365 , at 191-92.

367. Id. at 192 and sources cited therein.

368. Id. at 193.

369. Shikita, supra note 206 , at 82 .

370. It has been argued, see sources cited supra note 2, that statistics on the clearance rate in Japan are significantly overstated. Whether or not this is true, to the extent that the population as a whole (and in particular the population of potential offenders) believes that detection and apprehension are relatively certain, there may be no need for harsh penalties to achieve a significant general deterrent effect.

371. Braithwaite asserted that his reintegrative-shaming model offered great promise for reducing crime, see BRAITHWAITE, supra note 14 , at $61-65,75,120$, and thus he would likely go much further than I would in this regard. In my view, certain important aspects of Japanese society-in particular the wide range of informal social controls-help account for both the low 
the crime rate, or other basic societal change, seriously weaken benevolent paternalisin in Japan?

In formulating an answer, it is useful to identify key facets of Japanese society and the criminal-justice system that help explain the functioning of Japan's benevolent-paternalisin model. A host of candidates exist, but let ine highlight five such features, most of which I have already mentioned and all of which are to a greater or lesser extent interrelated. First is a high degree of trust in criminal-justice officials. Second is a relatively high level of commumity cooperation and involvement in virtually all aspects of the criminal-justice system-from initial crime detection through reintegration of offenders. Third is relatively broad societal consensus on certain core values. Fourth is Japan's relatively high clearance rate and, fifth and finally, the low crime rate itself. ${ }^{372}$ None of these social factors is absolute, hence my frequent use of the term "relatively." Nor am I convinced that all of these elements are essential to a benevolent-paterualism model. Yet each facet of Japan's system histed above is currently subject to pressures that have the potential to transform the benevolent-paternahism model.

Given the crucial role of police and prosecutors in the Japanese system, loss of trust in those institutions could easily erode the effective functioning of criminal justice. One recent threat to that trust came from widespread media criticism accompanying the death-penalty retrial cases. The faulty investigations in each of those cases took place many years ago, however, and the general public appears to have dismissed them as aberrational.

An additional hidden danger to law enforceinent lies in the procuracy's recent difficulty in attracting new recruits. ${ }^{373}$ This threat,

crime rates and the evident success of the benevolent-paternalism model. I am not persuaded that such a system can successfully be grafted onto a society where such conditions do not exist.

372. One other factor merits mention: Japan's strict gun-control laws, which prohibit anyone but law enforcement personnel from carrying small firearms. See JūHō TŌKENRUI SHOJiTō TORISHIMARIHō [FIREARMS AND SwordS ConTrol LAw] art. 3 (Law No. 6 of 1958). This undoubtedly has helped to limit the number of violent crimes. That, in turn, might indirectly reduce retributive pressures on the system.

373. Ironically, it is possible that elimination of the suspension-of-prosecution doctrine could result in a drastic decline in the number of prosecutors. A prosecutor has suggested to me that many prosecutors find the suspension-of-prosecution doctrine, and the consequent opportunity for prosecutors to play an active role in both the rehabilitation of offenders and the settlement of cases without trial, to be the most attractive and satisfying part of their job. Without the doctrine, this prosecutor suggests, few graduates of the Legal Research and Training Institute would opt for the procuracy. Conversation with Haruki Sugiyama, Tokyo District Public Prosecutor's Office, in Seattle, Wash. (Mar. 1990). Many years ago, another prosecutor expressed much the same view: "The role of the prosecutor is to provide the offender with the opportunity for self-reform. By suspending prosecution we can anticipate rehabilitation. The very existence of the system of suspension of prosecution makes it worth being a prosecutor." Hiromi Nagato, Kiso yüyo to in koto [This Thing Called Suspension of Prosecution], in Tsumi to batsu [CRIME and PUNishment] 2-12 (1964), quoted in Momose et al., supra note 188, at 6 (translation by the author). 
too, seems quite remote. It would take a dramatic decline in ability or numbers to seriously affect public trust in prosecutors.

The second and third eleinents-community cooperation and sliared values-are niore probleniatic. In discussing these closely related characteristics of the system it is useful to distinguish between internal and external sources of erosion.

The greatest external cliallenge to benevolent paternalism coines in the form of an influx of foreigners. As discussed earlier, criminal-justice autliorities have reported practical difficulties in dealing with offenses by foreigners. ${ }^{374}$ Differences in language, together with real or perceived differences in values and the perception of lower prospects for reintegration, make it probable that criminal-justice autlorities will concentrate siniply on processing such cases efficiently. They are unlikely to devote significant resources to reliabilitation and reintegration. Thus, the criminal-justice process for most crimes by foreigners is likely to follow a separate track, in whicl "benevolence" will play a limited role. Troubling as I find its inherent bias, that approacli will probably not undermine the existing systein. Ratlier, the additional track is likely to coexist alongside the benevolent-paternalism track, at least until Japanese society and officialdonı recognize immigrants and otler minorities as anything other tlian a limited exception to the "Japanese" norm.

A greater threat to benevolent paternalism as a system would arise from an internal breakdown in attitudes toward conımunity cooperation and in notions of sliared values among the Japanese inajority. Despite the central importance of police and prosecutors in the formal crininal process, Japan's criminal-justice systenı depends heavily on community cooperation and informal social controls at all levels, from crime prevention and detection ${ }^{375}$ through reliabilitation and reintegration. ${ }^{376}$ For the purposes of criminal justice, of course, the relevant communities are not simply geographic: family, company, and other social groupings play vital roles. A sense of sliared values undoubtedly enables these mechanisnis to address the probleins of crime more effectively.

The importance of these supporting institutions and ideas suggests a wide range of potential threats to benevolent paternalism in Japan. Urbamization continues unabated. The nuclear family has long since displaced the extended family as the norm. Some observers now speak of a younger generation of "new humans" wlio, like the "me generation," supposedly think only of theinselves. ${ }^{377}$ In the long term, developments

374. See supra text accompanying note 330 .

375. See BAYLEY, supra note 1 , at 86-97.

376. See, e.g., Tanigawa, supra note 252.

377. See, e.g., Peter Tasker, Inside JAPan: Wealth, Work and PoWer IN the NeW JAPANESE EMPIRE 96-99 (1987). 
of this sort might make it increasingly difficult for Japan to maintain its current approach to criminal justice. But I would hesitate to predict the demise of the present system on the basis of factors such as these. Urbanization and the rise of the nuclear family are by no means new phenoinena. And even if one accepts popular accounts of the characteristics of the "new humans" (which I find grossly overstated), rebelliousness and rejection of authority are not among them. ${ }^{378}$ Reports that younger Japanese are less willing than previous generations to play an active role in rehabilitation services might represent a greater cause for concern about the continued functioning of the benevolent-paternalism model. ${ }^{379}$ So long as family, coinpany, or other support groups remain intact and willing to take responsibility for supervision and rehabilitation of offenders, however, that developinent might not have great impact.

Finally, the high reported clearance rate and the low crime rate might help ensure the effective functioning of the benevolent-paternalism model in Japan. As noted earher, if potential offenders perceive a high likelihood of apprehension, even low penalties might suffice to deter criminal conduct. ${ }^{380}$ Further, low overall crime rates presumably allow police and prosecutors to devote time and effort to rehabilitation that they could ill afford if overwhelmed with the sheer volume of cases. ${ }^{381}$

378. See id. at 98 (stating that new humans are "notable not for their rebelliousness but for their meek conformism: not for their political radicalism but for their yawning apathy").

379. See supra note 257.

380. See supra note 370.

381. These factors suggest that, quite apart from due-process and other concerns, adopting elements of the benevolent-paternalism model might not be practicable in the United States. Aftcr all, one of Packer's basic assumptions nearly a quarter of a century ago was that he was considering a society in which "the magnitudes [of crime] being dealt with are very large, and the resources for dealing with [it] are very limited." PAcker, supra note 10, at 159.

Botly the intrusiveness and the comprehensiveness of Japanese criminal justice further mitigatc against the application of benevolent patemalism in an American setting. In the United States, distrust of authority runs deeper than in Japan; there is in the United States both greater emphasis on individuality and privacy and greater disagreement over many of the aims and values of the criminal-justice system. Japan's emphasis on confession and repentance obviously runs squarely against the strongly held American notions of the right to silence and personal autonomy. Thc importance accorded restitution in Japan creates the potential for unequal treatment on the basis of wealth, and the weight given to the views of victins creates the potential for a broad play of retributive urges.

Certain elements of benevolent paternalism might be more appealing to Anericans if limited to postconviction application. Notwithstanding the recent trend in the United States toward determinate sentences, traditionally much greater discretion has been deeined proper once a suspect has been convicted; explicit consideration of some individualized circumstances is expected even under determinate sentencing. Moreover, a number of communities in the United States havc begun utilizing alternative-sentencing approaches, which frequently incorporate features reminiscent of the Japanese systein. See Haley, supra note 279 (analyzing victin-offender mediation programs in the United States, Canada, and the United Kingdom); Randolph Picht, County Makes Alternative Sentencing Work, L.A. TIMES, Nov. 15, 1987, at 14 (describing the alternative-sentencing program of Genesee County, New York). These features include emphasis on confession and repentance at the point of sentencing, the use of victim-offender reconciliation, and cominunity involvement in 
Thus a significant decline in the clearance rate (or in public perceptions of the likelihood of apprehension) or rapid increases in crime might also weaken the viability of the systein.

The overall crime rate has risen gradually since the mid-1970s, but is still lower than in any postwar year up through 1965; it remains far lower than in most other mdustrialized nations. ${ }^{382}$ Reported clearance rates, on the other hand, have dropped significantly in the past four years, from a rate for major crimes of over $60 \%$ in 1987 to under $45 \%$ in $1990 .^{383}$ Nearly the entire basis for this difference is a decline in the clearance rate for larceny, by far the largest category of crime on the hist. $^{384}$ If Shikita is right about the crucial miportance of a high clearance rate, this trend, if it continues, could erode general deterrence im Japan.

For criminal-justice officials currently, however, the threat of drugs appears to represent an area of far greater concern than larceny or other traditional crimes. Despite highly pubhicized fears, ${ }^{385}$ drug offenses do not seein to be increasing rapidly. In fact, the total number of drug offenders apprehended by police has decreased in recent years. ${ }^{386}$ Yet drug offenses are difficult to detect, and if undetected drug use were to become widespread officials might feel compelled to compensate for the lower apprehension rate by increasing penalties. In that case, the need to achieve greater general deterrence could overwhelin the attention to individuahzed rehabilitative needs. ${ }^{387}$

reintegration efforts. Such an approach might hold promise at the community or regional level in some areas of the United States. On the whole, however, I am skeptical about applying benevolent paternalism on a widespread basis in the United States. I would be very fearful, moreover, of any calls to emulate the Japanese system writ large, including its investigative approach. Even assuming good intentions on the part of justice authorities, it is all too possible that concern for rehabilitation and reintegration would be lost along the way, leaving only the crime-control elements remaining.

382. 1991 HōMU SOGo KENKYŨSHo, HōMUSHō, HANZAI HAKUSHo [RESEARCH AND Training INST., Ministry of Justice, White Paper on CRime] 4 [hereinafter 1991 Hanzai HAKUSHO].

383. Id. at 6; RESEARCH AND TRAining INST., MinistRy of Justice, Gov'T of JAPAN, SumMary OF THE White Paper ON CRIME 1990, at 9 (1991).

384. 1991 HANZAI HAKUSHO, supra note 382, at 6, 25.

385. See, e.g., Charles Smith, Dope Dealers' Delight, FAR E. Econ. Rev., Mar. 15, 1990, at 12.

386. 1991 HANZAI HAKUSHO, supra note 382, at 28.

387. This might already be happening. Over the past fifteen years, the percentages of identified drug offenders who are arrested and who are detained have risen, see 1989 HANZAI HAKUSHO, supro note 3, at 398 (tbl. IV-37), the percentage prosecuted has also risen (and percentage of suspension of prosecution has dropped), id. at $384-85$ (tbl. IV-27), and the average sentences have increased in length, compare 1988 REPORT OF JUDICIAL STATISTICS, supra note 4, at 214-15 (tbl. 36-3) with 2

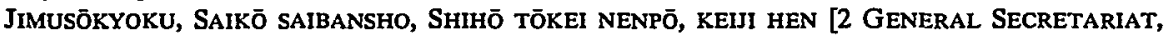
SUPReme Court, ANNuAl Report of Judicial Statistics, CRiminal CaSes] 218-19 (tbl. 36-3) (1975).

In some respects, drug cases find a parallel in election-law violations in Japan, which are thought to be widespread but largely undetected. In dealing with those cases, investigators do in fact cite a need for more intrnsive investigative techniques and even more intensive questioning than is the norm; sentences, however, are generally light. See White PAPER ON Crime 1988, supra note 1, at 107 (tbl. III-9). 
Justice officials are not willing to concede the first part of that battle. In emphasizing the importance of high clearance rates, Shikita argued that the success of Japan's system im maintaining order depends not only on intensive questioning as a means to imduce repentance but also on close ongoing observation of the populace and the use of broad investigative tools. ${ }^{388}$ In order to ensure high clearance for drug crimes, some other justice officials have argued for even broader enforcement weapons than they now possess, including wiretaps, sting operations, plea bargain$\mathrm{mg}$, and grants of immunity from prosecution. ${ }^{389}$ Whether they will gain those tools is unclear. ${ }^{390}$ The basis of their appeal, however, is familiar: provide us-the appropriate authorities-with the tools we need to detect crime, and then trust us to use the tools properly.

In the final analysis, although Japan's crimimal-justice system faces a wide range of pressures, those pressures probably will not alter the, system's underlying ethos anytime soon. The conscious emphasis on rehabilitation and remtegration has been a prominent feature of Japan's crimmal-justice regime, both $\mathrm{m}$ rhetoric and in practice, since early in this century. Justice authorities have had little cause to question the results this emphasis has produced. When the system is forced to confront new stresses-such as mcreased crime by foreigners or rising drug offenses-the response is not hikely to be sweeping change in the system itself. Rather, change will take the form of incremental adaptation, carving out exceptions where they are deemed necessary to deal with new issues. The specific responses likely with respect to foreigners and drugs-one encompassing a greater possibility of bias, the other a potential hicense for even greater imtrusions on personal autonomy-serve as final reminders that the benevolent-paternalism model, for all its strengths, comes at a price.

388. See Shikita, supra note 206 , at 82,89 n.1.

389. See supra note 294 and accompanying text.

390. One court has now authorized the use of wiretaps in drug cases. See supra note 292. In addition, the Diet recently enacted two laws providing certain other new weapons against drugs, including provisions relating to controlled delivery, money laundering, and confiscation of proceeds. See Hideki Tarumi, Yakubutsu ran'yö mondai ni kansuru kokusaiteki torikumi to mayaku nihö [International Grappling with the Drug Abuse Problem and the Two Narcotics Laws], 992 JURISUTo 69, 73-76 (1991). 